CINTIA LIMA DE OLIVEIRA SANTOS

\title{
Ensino da escrita em inglês com foco no \\ desenvolvimento: uma análise das concepções de língua e escrita dos alunos
}

Dissertação apresentada ao Programa de PósGraduação em Estudos Linguísticos e Literários em Inglês, do Departamento de Letras Modernas da Faculdade de Filosofia, Letras e Ciências Humanas da Universidade de São Paulo para a obtenção do título de Mestre em Letras.

Área de concentração: Linguística Aplicada

Orientadora: $\operatorname{Prof}^{\mathrm{a}} \mathrm{Dr}^{\mathrm{a}}$ Marília Mendes Ferreira

São Paulo 
Nome: SANTOS, C. L. de O.

Título: Ensino da escrita em inglês com foco no desenvolvimento: uma análise das concepções de língua e escrita dos alunos

Dissertação apresentada ao Programa de PósGraduação em Estudos Linguísticos e Literários em Inglês, do Departamento de Letras Modernas da Faculdade de Filosofia, Letras e Ciências Humanas da Universidade de São Paulo para a obtenção do título de Mestre em Letras.

Área de concentração: Linguística Aplicada

Orientadora: $\operatorname{Prof}^{\mathrm{a}}$ Dr$^{\mathrm{a}}$ Marília Mendes Ferreira

Aprovada em:

\section{Banca Examinadora}

Prof. (a) Dr. (a) Instituição:

Julgamento: Assinatura:

Prof. (a) Dr. (a) Instituição:

Julgamento: Assinatura:

Prof. (a) Dr. (a) Instituição:

Julgamento: Assinatura: 
“Tudo o que o homem semear, isso também ceifará." Bíblia Sagrada 


\section{AGRADECIMENTOS}

Primeiramente, a DEUS, por TUDO... pela VIDA, pela FORÇA e pela PAZ concedidas. Sem Sua ajuda este trabalho jamais poderia ter sido realizado.

Aos meus pais, Gilvan e Vera Lúcia, por todo esforço, toda dedicação, todo amor e toda paciência ao ficar com os meus filhos. E por tudo que me ensinaram e fizeram por mim... por meus irmãos... e por todos que passaram e ainda passam em suas vidas. Que Deus os retribua milhões e milhões de vezes mais... aqui e no Seu Reino de Glória.Vocês foram, são e sempre serão, em tudo, um exemplo em minha vida. Amo vocês.

Aos meus filhos, Ester e Davi, e meu marido, Mauro, por todo amor, paciência, compreensão e carinho. Amo vocês.

Aos meus irmãos, Eliel, Marcos e William, pelo carinho, incentivo, oração e colaboração nos momentos difíceis.

Aos amigos e parentes com quem compartilhei poucos, mas bons momentos de paze alegria.

Em especial, aos meus tios Toninho e Jorge, nos quais muitas vezes me inspirei e me espelhei.

Ao meu sogro, Sr. Valfredo dos Santos, pelo exemplo de pessoa que é, pela ajuda em oração e pelos livros que me enviou da terra do tio Sam.

Às minhas amigas, Mileide e Aleksandra, por sua amizade sincera e oração.

À CAPES, pelo reconhecimento e apoio financeiro.

Aos funcionários do DLM, em especial, à Edite - sempre pronta a ajudar.

À minha orientadora, $\operatorname{Prof}^{a}$ Dr $^{a}$ Marília Mendes Ferreira, pelo conhecimento e pela experiência compartilhados, pelas discussões e reflexões realizadas, pelos desafios impostos e, enfim, pelo crescimento pessoal e profissional que me proporcionou. 
Às professoras Marta Kohl de Oliveira e Walkyria Monte Mór pelas discussões e reflexões em aula e pelo modo significativo que marcaram minha vida. Vocês são exemplos de profissionais e de pessoas que certamente contribuem para que este seja um mundo melhor. À professora Elizabeth de LaTaille e, também, novamente, à professora Walkyria Monte Mór, pelas valiosas contribuições por ocasião do Exame de Qualificação.

Aos alunos do curso de extensão que serviu de base para esta pesquisa. Sem dúvida, vocês foram o meu maior desafio e também minha maior inspiração.

Enfim, a todos que, direta ou indiretamente, contribuíram para a realização deste trabalho...

MUITO OBRIGADA!!! 


\section{Resumo}

SANTOS, C. L. de O. Ensino da escrita em inglês com foco no desenvolvimento: uma análise das concepções de língua e escrita dos alunos. 2011. 183 p. Dissertação (Mestrado em Letras) - Faculdade de Filosofia, Letras e Ciências Humanas, Universidade de São Paulo, São Paulo, 2011.

Esta pesquisa focaliza as concepções de língua e escrita de alunos de um curso de escrita em inglês fundamentado na perspectiva conceitual (FERREIRA, 2005), uma abordagem para o ensino da escrita em língua estrangeira que alia a escola australiana de gêneros textuais a uma pedagogia baseada na teoria da atividade, conhecida como MAC (Movimento do Abstrato para o Concreto). Com base nos pressupostos da perspectiva vygotskiana (VYGOTSKY, 1978, 1987) e tendo como referência as concepções de língua e escrita subjacentes às três principais abordagens para o ensino da escrita em inglês, tradicional, processual e social (cf. FERREIRA, 2005, 2011), buscou-se verificar se ocorre ou não mudança nas concepções de língua e escrita dos alunos ao longo do curso. Planejado e ministrado pela própria pesquisadora, o curso intitulado "Praticando a escrita em inglês por meio de gêneros textuais: a argumentação", foi oferecido como curso de extensão em uma universidade pública do estado de São Paulo. Participaram da pesquisa seis alunas, com idades entre 23 e 51 anos. A maioria possui graduação em Letras e apenas uma não é pós-graduada. A seguinte pergunta de pesquisa foi elaborada: houve mudança nas concepções de língua e escrita dos alunos ao longo do curso? Para responder a essa pergunta de pesquisa, foram identificadas as concepções de língua e escrita das participantes no início ( $1^{\mathrm{a}}$ etapa da análise) e ao longo do curso ( $2^{\mathrm{a}}$ etapa da análise). Os dados coletados no início do curso correspondem às respostas das alunas às perguntas feitas pela instrutora em uma Ficha de Identificação e em um Teste de Proficiência. A análise desse primeiro conjunto de dados revelou concepções tradicionais de língua e escrita por parte das alunas, decorrentes, principalmente, 1) de sua crença na necessidade de conhecimentos relacionados à gramática e a vocabulário, 2) da apresentação de objetivos categorizados como 'escolar' e 'emocional', 3) da experiência mecânica e descontextualizada que tiveram com a escrita no contexto escolar e 4) da ausência quase total de usos significativos da escrita em seu dia a dia. Os dados coletados ao longo do curso correspondem às declarações e respostas das alunas às perguntas feitas pela instrutora em seus diários dialogados. A análise desse segundo conjunto de dados revelou, por sua vez, o início de um processo de mudança propiciado pelas reflexões realizadas em aula e em seus diários. Podemos dizer que esse estudo confirmou a importância do foco nas crenças e, principalmente, na mudança de crenças no processo de ensino e aprendizagem de línguas considerando-se, sobretudo, a precariedade do ensino da 
escrita nos dias atuais, como revelam estudos recentes nessa área (FERREIRA, 2011; RIOS, 2010).

Palavras-chave: ensino da escrita em inglês, perspectiva vygotskiana, abordagem conceitual, concepções de língua e escrita. 


\begin{abstract}
SANTOS, C. L. de O. Teaching writing in English with focus on development: an analysis of students' conceptions of language and writing. 2011. 183 p. Dissertation (Master's degree in Applied Linguistics) - Faculdade de Filosofia, Letras e Ciências Humanas, Universidade de São Paulo, São Paulo, 2011.
\end{abstract}

This research investigates the conceptions of language and writing of six students in an English writing course based on the conceptual approach (FERREIRA, 2005), a perspective for teaching second language writing which joins the Australian school of genres with a pedagogy based on Activity Theory called 'Movement from the Abstract to the Concrete' (MAC). Based on Vygotsky's theory (VYGOTSKY, 1978, 1987) and on the conceptions of language and writing from the three main approaches for second language writing teaching (see FERREIRA, 2005, 2011), this study analyses the changes in students' conceptions of language and writing along the course. Planned and organized by the researcher herself, the course named 'Praticando a escrita em inglês por meio de gêneros textuais: a argumentação', was offered as a short-time course in a public university in the city of São Paulo. The participants were between 23 and 51 years old. Most of them were graduate students of Language and only one was not yet post graduated. The following research question was formulated: Was there any change in the student's conception of language and writing along the course? In order to answer this question, we identified the student's conceptions of language and writing in the beginning and along the course. The data collected in the beginning of the course corresponded to the students' answers to questions formulated by the instructor in a Identification Form and in a Proficiency Test. The analyses of this group of data revealed traditional conceptions of language and writing on the part of the students, represented, mainly, by 1) their beliefs in the necessity of grammatical and lexical knowledge, 2) by the presence of objectives categorized as 'scholastic' and 'emotional', 3) by their mechanical and de-contextualized experience with writing in school and 4) by the absence of significant uses of writing in their ordinary life. The data collected along the course corresponded to free declarations and the students' answers to questions formulated by the instructor in their dialogue journals. This second group of data revealed the beginning of a changing process in the students' conceptions of language and writing as a result of the reflections done in class and in their dialogue journals. We can say that this research confirmed the importance of focusing on beliefs and, mainly, on beliefs' changes in the process of language teaching and learning, considering the problems faced by the teaching of second language writing, as recent studies have shown (FERREIRA, 2011; RIOS, 2010). 
Keywords: teaching of writing in English, sociocultural theory, conceptual approach, students' conceptions of language and writing 


\section{LISTA DE TABELAS}

Tabela 1 - Fontes de dados e abreviações. .56

Tabela 2 - Fontes, dados e unidades de análise. .57

Tabela 3 - Perfil dos participantes. .59

Tabela 4 - Conhecimento e contato com a língua inglesa......................................................60

Tabela 5 - Abordagens e respectivas concepções de língua e escrita.....................................62

Tabela 6 - Abordagens e práticas de ensino relacionadas....................................................63

Tabela 7 - Expressões que indicam os objetivos dos participantes em relação ao curso e/ou à escrita.

Tabela 8 - Usos, frequência de usos e dificuldades das participantes em relação à escrita......65

Tabela 9 - Categorização dos objetivos e exemplos...........................................................67

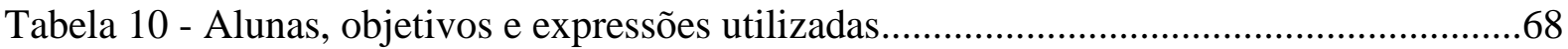

Tabela 11 - Recorrência das categorias de objetivos......................................................... 70

Tabela 12 - Gosto e interesse pela língua inglesa.............................................................71

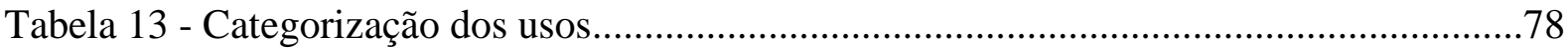

Tabela 14 - Participantes, categorias de usos e expressões utilizadas ...........................................79

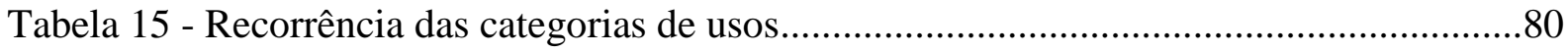

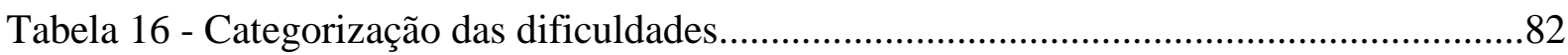

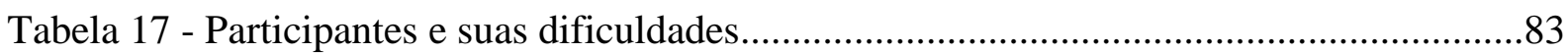

Tabela 18 - Recorrência das categorias de dificuldades......................................................84

Tabela 19 - Sentimentos em relação à escrita em inglês e desempenho em língua materna....89 


\section{LISTA DE GRÁFICOS}

Gráfico 1 - Recorrência das categorias de objetivos........................................................ 70

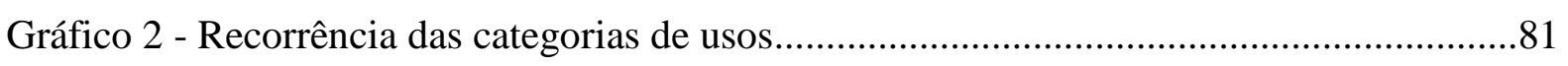

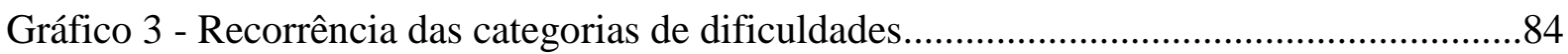




\section{SUMÁRIO}

1. Introdução.

2. Fundamentação teórica. .18

2.1. A perspectiva sócio-histórico-cultural. .18

2.2. Abordagens para o ensino da escrita em L2... .24

2.3. A perspectiva conceitual. 33

2.3.1. A pedagogia davydoviana. .33

2.3.2. SFL e a pedagogia davydoviana: a constituição da perspectiva conceitual........40

2.4. Sobre o curso. .44

2.4.1. Informações gerais .44

2.4.2. Descrição das ações pedagógicas do curso. .47

3. Metodologia. .56

3.1. Contexto e participantes. 58

4. Análise e discussão dos dados 61

4.1. $1^{\mathrm{a}}$ etapa da análise .63

4.1.1. Análise dos dados referentes aos objetivos (tabela 7). .66

4.1.1.1. Categorização dos objetivos. .66

4.1.1.2. Considerações preliminares referentes aos objetivos. .71

4.1.2. Análise dos dados referentes aos usos/frequência de usos e dificuldades (tabela $8)$ .78

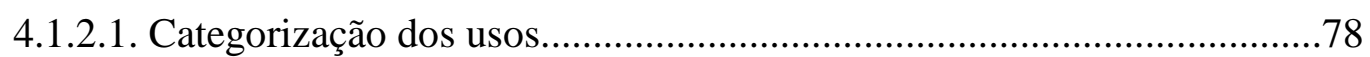

4.1.2.2. Categorização das dificuldades..........................................................82

4.1.2.3. Considerações preliminares referentes aos usos, dificuldades e sua relação com os objetivos. .85

4.1.3. Discussão dos resultados da $1^{\mathrm{a}}$ etapa da análise (tabelas 7 e 8)........................91

4.2. $2^{\mathrm{a}}$ etapa da análise.

4.2.1. Atividades realizadas nas aulas e ações desenvolvidas pela instrutora para promover a mudança nas concepções de língua e escrita dos alunos. 


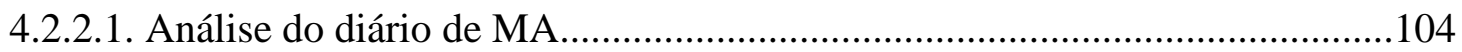

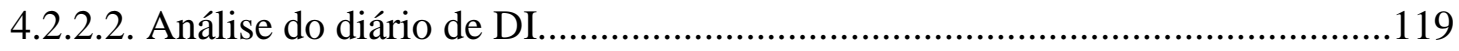

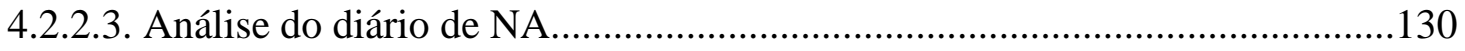

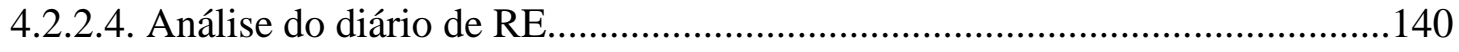

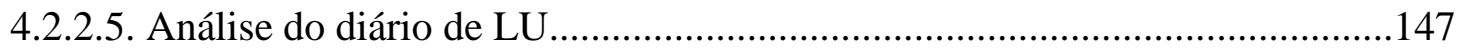

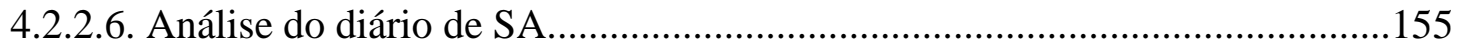

4.2.3. Discussão dos resultados da $2^{\mathrm{a}}$ etapa da análise..............................................161

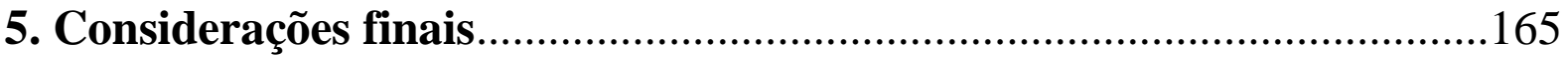

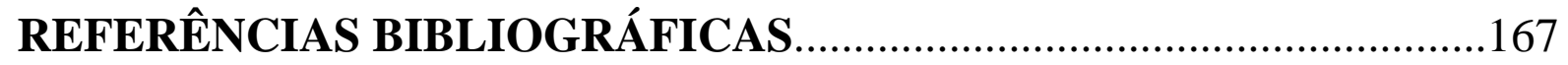

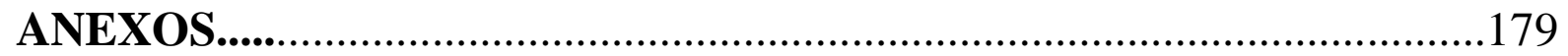




\section{Introdução}

Ensinar língua estrangeira, especialmente, no mundo globalizado e marcado pela pluralidade linguística e cultural que hoje vivemos (LANKSHEAR; KNOBEL, 2003; GEE, 2000; LUKE, 2000), não pode significar, simplesmente, capacitar os alunos para dominarem mais um sistema de códigos, mas prepará-los para interagir em um espaço sócio-histórico e cultural muito mais amplo e complexo.

De um ponto de vista da perspectiva sócio-histórico-cultural (VYGOTSKY, 1978, 1987), o aprendizado impulsiona o desenvolvimento, e não o contrário, por isso, é importante que o ensino focalize as capacidades cognitivas dos alunos e não apenas a transmissão de conhecimento. O desenvolvimento humano, segundo essa perspectiva, ocorre a partir da atividade prática do homem no mundo, que se dá, por sua vez, por meio do uso de instrumentos físicos e simbólicos, sendo a linguagem o mais importante deles. Nesse sentido, o desenvolvimento humano constitui um processo que se inicia na esfera social e, por meio do processo de internalização dos instrumentos simbólicos, transforma-se em sócio-cognitivo, levando o indivíduo a graus cada vez maiores de controle e autonomia.

Nessa perspectiva, as práticas de ensino devem ser concebidas como propiciadoras do desenvolvimento da capacidade dos alunos de utilização dos instrumentos simbólicos produzidos pelas sociedades (dados pela cultura), de modo que se tornem mediadores das atividades práticas dos indivíduos no mundo. Partindo desses princípios, DAVYDOV (1999) desenvolveu uma pedagogia com foco na promoção do pensamento teórico dos alunos, compreendido como o pensamento dialético utilizado para a formação de conceitos científicos. Nessa perspectiva, os conceitos científicos 
aprendidos constituem a mediação entre o indivíduo e o mundo, o principal instrumento simbólico utilizado para a solução de problemas.

Ferreira (2005) utilizou os princípios dessa pedagogia, aliando-a à escola australiana de gêneros textuais, e desenvolveu uma abordagem para o ensino da escrita em língua estrangeira em que o gênero textual é ensinado como conceito científico e manifestação do princípio comunicativo abstrato $(A C P)$, representado pela relação dialética língua-contexto ${ }^{1}$. Por meio dessa abordagem - a perspectiva conceitual (FERREIRA, 2005; FERREIRA; LANTOLF, 2008) - espera-se que o aluno entenda gênero não como um modelo a ser seguido (ou como um elemento de limitação às suas produções), mas como uma ferramenta conceitual/simbólica para auxiliá-lo em (mediar) suas atividades práticas no mundo, realizando-as de maneira cada vez mais autônoma, crítica e criativa.

$\mathrm{O}$ curso que serviu de base para essa pesquisa fundamentou-se na abordagem conceitual desenvolvida por Ferreira (2005) e, dessa forma, objetivou promover o pensamento teórico dos alunos. Como veremos, mais detalhadamente, na fundamentação teórica desse estudo, o pensamento teórico pode ser promovido por meio da aplicação de algumas ações que objetivam também desenvolver no indivíduo as capacidades de auto-controle e avaliação do seu próprio processo de aprendizagem. Nesse sentido, a primeira ação a ser desenvolvida corresponde à apresentação de uma situação-problema que leve o aluno a perceber a necessidade daquilo que o curso se propõe a ensinar, tornando o aprendizado significativo e envolvendo o aluno na descoberta do seu objeto de estudo. No curso implementado para essa pesquisa, a situação-problema problema seria apresentada em forma de uma questão-problema que,

\footnotetext{
${ }^{1}$ A expressão língua-contexto representa a relação dialética estabelecida entre indivíduo, língua e sociedade e, nesse sentido, engloba história individual e social e cultura.
} 
por sua vez, previa concepções de língua e escrita por parte dos alunos, ligadas à abordagem social e, portanto, à visão de língua (e escrita) como prática social. No entanto, logo no início do curso, foi possível observar que suas concepções de língua e escrita estavam ligadas à abordagem tradicional de ensino da escrita, ou seja, que concebiam língua e escrita como demonstração de conhecimento gramatical e lexical.

Considerando-se que as concepções (e as crenças, de um modo geral) tem um papel fundamental no processo de desenvolvimento cognitivo dos indivíduos (de um ponto de vista da perspectiva vygotskiana), além das ações previstas para o curso, outras com foco na mudança das crenças dos alunos foram incluídas. E, nesse sentido, a intervenção baseou-se, sobretudo, em reflexões em aula e com a instrutora por meio de diários dialogados enviados e recebidos por e-mail. Dessa forma, os dados coletados representam o registro das concepções tradicionais que as participantes da pesquisa apresentaram no início do curso e do processo de mudança propiciado por esse tipo de intervenção. A classificação das concepções de língua e escrita dos alunos foi feita a partir de Ferreira $(2005,2011)$ que aponta a existência de três principais abordagens para o ensino da escrita em língua estrangeira relacionadas a diferentes concepções de língua, escrita e seu ensino (abordagem tradicional, processual e social). Como veremos, o foco na mudança das concepções dos alunos teve resultados muito positivos em seu processo de aprendizagem da escrita, como sugerem os estudos recentes sobre crenças (SILVA, 2010; MICCOLI, 2010).

Do ponto de vista da perspectiva sócio-histórico-cultural, além de prática social, a escrita é considerada instrumento simbólico (um dos mais importantes das sociedades modernas) responsável pela promoção do desenvolvimento psicológico (intelectual) dos indivíduos. Sendo os instrumentos simbólicos (ou psicológicos) fornecidos pelas culturas, podemos dizer que as diferentes práticas de escrita estão diretamente 
relacionadas às maneiras como os indivíduos concebem escrita ou, em outras palavras, às crenças sobre ela (e, acrescentamos, sobre a língua de um modo geral) formadas ao longo de suas vidas (ontogênese). Nesse sentido, torna-se fundamental, no processo de ensino-aprendizagem da escrita, a análise das concepções (ou crenças) de língua e escrita dos alunos de modo que seja possível identificar seu nível de desenvolvimento real (sua capacidade de domínio e utilização dessa modalidade da língua) e, dessa forma, criar zonas de desenvolvimento potenciais (por meio da aplicação de atividadesproblemas que possibilitem aos alunos novas formas de utilização e, consequentemente, novas formas de conceber língua e escrita) levando à promoção do seu desenvolvimento psicológico (intelectual). 


\section{Fundamentação teórica}

Esta pesquisa fundamenta-se na perspectiva sócio-histórico-cultural ${ }^{2}$ desenvolvida a partir dos trabalhos de Vygotsky (1978/2007, 1987/2008) e seus colaboradores (LEONTIEV, 1978, 1981; LURIA, 1976, 1979) - e na perspectiva conceitual (FERREIRA, 2005), uma abordagem para o ensino da escrita em língua estrangeira que alia a pedagogia davydoviana (DAVYDOV, 1999) à escola australiana de gêneros textuais (MARTIN, 1989, 1993, 1999).

A perspectiva sócio-histórico-cultural constitui uma teoria do desenvolvimento humano e será utilizada para auxiliar na investigação do desenvolvimento cognitivo dos alunos participantes da pesquisa, sobretudo, das suas concepções de língua e escrita. Considerada, ao mesmo tempo, conforme salienta Bruner (1987), "uma teoria da educação" e "uma teoria da transmissão cultural” (p. 1), essa perspectiva servirá, também, para fundamentar a análise das práticas de ensino de um modo geral utilizadas pela instrutora em sala de aula. A perspectiva conceitual, por sua vez, constitui a abordagem utilizada no curso que serviu de base para esta pesquisa.

\subsection{A perspectiva sócio-histórico-cultural}

Lev Semenovitch Vygotsky nasceu em uma pequena cidade chamada Orsha, na Rússia, em 1896. Fazia parte de uma família judia de condições econômicas estáveis e considerada uma das mais cultas da cidade. A maior parte da sua educação foi realizada por tutores particulares, até quando, aos quinze anos, ingressou em uma escola particular, onde concluiu o curso secundário. Em 1917, formou-se em Direito pela

\footnotetext{
${ }^{2}$ Essa perspectiva é também chamada de teoria vygotskiana, sócio-cultural ou histórico-cultural.
} 
Universidade de Moscou, "na época, [...] um curso amplo na área de ciências humanas, incluindo o que atualmente corresponderia a Direito e Literatura" (OLIVEIRA, 1998, p. 19). Durante a graduação chegou a frequentar cursos de História e Filosofia em outra universidade, aprofundando seu conhecimento em psicologia, filosofia e literatura. Iniciou sua carreira profissional como professor de literatura e atuou, posteriormente, em diversas instituições de ensino e pesquisa nas áreas de literatura, filosofia, pedagogia e psicologia. Seu trabalho sistemático no campo da psicologia iniciou-se apenas em 1924, com a apresentação de uma palestra no II Congresso soviético de neuropsicologia. Dez anos mais tarde, morreu de tuberculose, aos trinta e sete anos (BRUNER, 1987; COLE; SCRIBNER, 2007; OLIVEIRA, 1998).

Segundo Cole e Scribner (2007), a sociedade em que Vygotsky viveu e trabalhou, a Rússia pós-revolução, buscava na ciência - altamente valorizada - a solução para os seus problemas sociais e econômicos mais prementes. No contexto em que Vygotsky atuou, em sua maior parte a área da Educação, esperava-se que a ciência pudesse auxiliar, por exemplo, na eliminação do analfabetismo e na implementação de programas "que maximizassem as potencialidades de cada criança" (p. XXIX). Apesar de não ter tido formação específica em Psicologia, Vygotsky via nessa ciência o caminho para o enfrentamento dessas e outras questões. No entanto, ele entendia que, para isso, seria necessário uma reforma da Psicologia que, na época, encontrava-se dividida em duas tendências e que, segundo seu ponto de vista (e de outros estudiosos de sua época), não podiam tratar essas questões adequadamente. Foi seu empenho em tentar resolver essa crise na Psicologia, que Vygotsky, juntamente com seus colaboradores, lançou as bases da teoria sócio-histórico-cultural.

A Psicologia encontrava-se dividida da seguinte maneira: uma psicologia que se aproximava das demais ciências experimentais (como a física e a biologia) e que 
procurava explicar os processos psicológicos elementares (percepção sensorial e reflexos); e uma psicologia mais próxima das ciências humanas (como a filosofia) e que procurava descrever de maneira global e subjetiva os processos psicológicos superiores (planejamento, atenção voluntária, memória lógica, solução de problemas e avaliação desses processos (APPEL; LANTOLF, 1994)) (COLE; SCRIBNER, 2007; OLIVEIRA, 1998).

O objetivo de Vygotsky, conforme explica Cole e Scribner (2007), era criar uma Psicologia que abordasse os processos psicológicos superiores em termos aceitáveis para a ciência. Em outras palavras, ele objetivava a criação de uma nova abordagem para a Psicologia, que fosse uma síntese das duas tendências, a partir de uma base teórica completamente nova. Essa base teórica correspondia ao materialismo histórico e dialético desenvolvido por Marx em $O$ Capital. Seu intuito era aplicar os princípios e métodos do materialismo histórico e dialético à Psicologia e, conforme ele mesmo explica, "criar o seu próprio Capital" (p. XXVII):

“[...] Para criar essa teoria-método [...] é necessário descobrir a essência desta determinada área de fenômenos, as leis que regulam suas mudanças, suas características qualitativas e quantitativas, além de suas causas. É necessário, ainda, formular as categorias e os conceitos que lhes são especificamente relevantes - ou seja, em outras palavras, criar o seu próprio Capital.

O Capital está escrito de acordo com o seguinte método: Marx analisa uma única 'célula' viva da sociedade capitalista - por exemplo, a natureza do valor. Dentro dessa célula ele descobre a estrutura de todo o sistema e de todas as suas instituições econômicas. [...] Alguém que pudesse descobrir qual é a célula 'psicológica' - o mecanismo produtor de uma única resposta que seja - teria, portanto, encontrado a chave para a psicologia como um todo" (manuscrito de Vygotsky de cadernos não publicados citado por Cole e Scribner (2007), p.XXVII).

Como é possível depreender das palavras de Vygotsky, os princípios do materialismo histórico e dialético resumem-se nas seguintes proposições: 
primeiramente, que todo fenômeno tem sua história e essa história é caracterizada por mudanças quantitativas e qualitativas (em forma, características e estruturas básicas); e, segundo, que mudanças históricas na sociedade e na vida material produzem mudanças na natureza humana. O método, por sua vez, consiste em estudar os fenômenos como processos em movimento e em mudança; em investigá-los em sua origem e desenvolvimento e descobrir sua célula (que corresponderá à unidade de análise). Em seus experimentos, Vygotsky desenvolveu técnicas como engajar o indivíduo em atividades variadas, introduzindo dificuldades (ou colocando o indivíduo frente a tarefas que excedessem em muito suas capacidades) e fornecendo caminhos alternativos para a solução de problemas. Seu objetivo era, dessa forma, “desvendar os processos [...] comumente [...] encobertos pelo comportamento habitual"; pôr "à mostra o curso real do desenvolvimento de uma determinada função"; evidenciar o início rudimentar de novas habilidades (COLE; SCRIBNER, 2007, p.XXXIII).

Em sua busca pela (ou apresentação daquilo que julgava ser a) "célula da psicologia”, Vygotsky (1987) elabora uma crítica profunda à noção de que as funções psicológicas superiores pudessem ser compreendidas a partir dos princípios da psicologia animal ou que fossem resultado apenas de um processo de maturação. Com o objetivo de refutar essas teorias, ele procura explicar as diferenças genéticas (de origens) entre o pensamento e a linguagem e como, no curso do desenvolvimento humano, esses processos se inter-relacionam e se transformam e, consequentemente, transformam o comportamento humano ${ }^{3}$. Partindo dessa discussão, Vygotsky (1978)

\footnotetext{
${ }^{3}$ Conforme explicam Cole e Scribner (2007), a preocupação de Vygotsky era mais apresentar os princípios e métodos de sua teoria do que desenvolver proposições baseadas em pesquisas empíricas por ele desenvolvidas e, nesse sentido, seus textos constituem-se basicamente críticas e reflexões em torno das questões que preocupavam a psicologia em sua época (a relação entre comportamento humano e animal; entre eventos ambientais e eventos mentais; e entre processos fisiológicos e psicológicos), tendo os dados empíricos e as referências às pesquisas realizadas (tanto por seus colaboradores como por outros estudiosos da época) o papel de apenas ilustrar e apoiar esses princípios.
} 
explica como a linguagem, ao ser utilizada como instrumento psicológico, funciona para transformar funções psicológicas elementares em funções psicológicas complexas, revelando, a partir desse ponto, qual seria a célula da psicologia.

Baseando-se em estudos sobre a linguagem e o intelecto dos macacos antropóides, Vygotsky (1987/2008) conclui que o pensamento e a fala têm raízes genéticas diferentes, e que, ao longo do desenvolvimento humano, é possível observar a existência de uma fase pré-verbal no desenvolvimento do pensamento e uma fase préintelectual no desenvolvimento da fala. Em um determinado estágio desse desenvolvimento, essas linhas se encontram e o pensamento torna-se fundamentalmente verbal e a fala intelectual (p.54)

Vygotsky (1987) explica que a fala é usada, a princípio, para estabelecer comunicação (corresponde ao que chama de "fala exterior") e que, durante o desenvolvimento do indivíduo, passa a funcionar também como organizadora do seu pensamento (corresponde à chamada "fala interior"). Essa transição entre um e outro estágio pode ser evidenciada pela chamada "fala egocêntrica" (a fala em voz alta para si mesmo, independentemente da presença de outras pessoas). A fala egocêntrica corresponderia à fala interior quanto à sua função e, nesse sentido, pode-se dizer que a fala é interiorizada psicologicamente antes de ser interiorizada fisicamente. O motivo dessa interiorização corresponde à mudança de função da fala. Segundo ele, esse mesmo curso é seguido por todas as funções psicológicas que envolvem o uso de signos (do social para o individual). Dessa forma, Vygotsky estabelece um dos pilares da teoria sócio-histórico-cultural: a noção de que o desenvolvimento intelectual humano

\footnotetext{
${ }^{4}$ Vygotsky (1987) explica que o pensamento segue um curso inverso ao da linguagem. Enquanto a aquisição da linguagem ocorre da parte para o todo (de palavras para frases, por exemplo), o pensamento manifesta-se do todo para as partes, conforme mostram estudos realizados com crianças. Outro fato que comprovaria essa teoria é a da polissemia da linguagem, o fato de uma palavra não corresponder a um mesmo e único significado.
} 
corresponde a um processo que parte do social (interpsíquico) para o individual (intrapsíquico), coerentemente, portanto, com a teoria marxista em que se apóia. Consegue identificar também o que considera a célula da psicologia, a sua unidade dialética de análise: a palavra, que contem em si tanto o aspecto do pensamento (o significado) como o da linguagem (o significante).

Vygotsky (1978) passa a investigar, a partir desse ponto, como a interiorização (ou internalização) dos sistemas de signos (considerando a linguagem o principal deles), produzidos culturalmente, promove transformações no comportamento humano. Seguindo os pressupostos do materialismo histórico e dialético e utilizando o conceito de mediação, por meio de instrumentos físicos e do trabalho, desenvolvido por Engels (1940), Vygotsky (1978) elabora o conceito de mediação por meio dos signos, considerados instrumentos simbólicos (ou psicológicos). Ele explica que, uma vez interiorizados, esses instrumentos psicológicos modificam as funções elementares e suas relações entre si, promovendo, dessa forma, uma re-organização das estruturas cerebrais e a emergência das funções psicológicas superiores e, consequentemente, da consciência. O conceito de mediação por meio de signos, desenvolvido por Vygotsky para explicar a origem da consciência humana, constitui, dessa forma, o mais importante princípio de sua teoria (LANTOLF, 2000).

A teoria elaborada por Vygotsky (1978/2007; 1987/2008) tem implicações diretas na educação, uma vez que considera o desenvolvimento humano um processo altamente dependente das relações estabelecidas entre os indivíduos em sociedade. É por meio dessas relações, mediadas por instrumentos físicos e simbólicos, que o ser humano desenvolve a capacidade de pensar de maneira lógica, de planejar, solucionar problemas, controlar suas ações etc. 
Ao investigar as funções psicológicas superiores no seu processo de desenvolvimento, Vygotsky elaborou um conceito que, apesar de muitas vezes mal interpretado, tem muito a contribuir para as práticas educativas de um modo geral, o conceito de "zona de desenvolvimento proximal". Conforme explica Vygotsky (2007, p.98), "a zona de desenvolvimento proximal define aquelas funções que ainda não amadureceram, (...) mas que estão em processo de maturação" e, que podem ser desenvolvidas com auxílio adequado. Este conceito nos ajuda a entender o curso do desenvolvimento de um indivíduo, uma vez que não considera apenas o que este consegue fazer sozinho, mas o que já tem capacidade de aprender (porque pode realizar com ajuda). Ele constitui, dessa forma, um conceito potencialmente eficiente no planejamento de pedagogias e práticas pedagógicas que visem ao desenvolvimento dos alunos.

Em sua corrida contra o tempo, à espera de uma morte por tuberculose que poderia ocorrer a qualquer instante, os escritos de Vygotsky não chegaram a constituir uma teoria explicativa completa do processo de desenvolvimento humano. No entanto, seus postulados foram desenvolvidos por seus colaboradores (LEONTIEV, 1978, 1981; LURIA, 1976, 1979) e, posteriormente, deram origem a importantes pedagogias (DAVYDOV, 1999; GALPERIN, 1989; HEDEGAARD, 2002; HEDEGAARD; CHAIKLIN, 2005) utilizadas nos dias atuais ${ }^{5}$.

\subsection{Abordagens para o ensino da escrita em língua estrangeira}

\footnotetext{
${ }^{5}$ Vygotsky lançou as bases do que viria a constituir a teoria da atividade, posteriormente, sistematizada por Leontiev (1979, 1981) e elaborada, sob outro viés, por Engstrom (1987). As pedagogias citadas baseiam-se na teoria da atividade, desenvolvida por Leontiev, em Vygotsky e nos princípios do materialismo histórico e dialético.
} 
Conforme aponta Ferreira (2005), é possível identificar três principais abordagens para o ensino da escrita em língua estrangeira: a abordagem tradicional, a processual e a social. Essas abordagens sustentam diferentes concepções de língua, escrita e texto, que nos ajudam a compreender as diferentes práticas de ensino consciente ou inconscientemente - desenvolvidas ao longo dos tempos. Essas práticas implicam diferentes objetivos a serem alcançados, sendo responsáveis, nesse sentido, por quanto o ensino da escrita em língua estrangeira tem contribuído (ou não) para a difícil tarefa da escola de formar indivíduos capazes de interagir efetivamente em sociedade. Nesse trabalho, o conhecimento dessas abordagens nos auxiliará na análise das concepções de língua e escrita dos alunos e na relação destas com as práticas de ensino desenvolvidas em aula.

A abordagem tradicional, fundamentada no behaviorismo, pressupõe (ao mesmo tempo em que promove) uma concepção de língua (e escrita) restrita ao vocabulário e à gramática e do conceito de texto como uma fórmula a ser aprendida e aplicada, sobretudo, no contexto escolar. Nesse sentido, as práticas de ensino baseadas nessa perspectiva preocupam-se em expor os alunos ao que consideram os bons textos com o objetivo de que estes sejam imitados (SILVA, 1990). Nessa perspectiva, o trabalho do professor limitar-se-ia à apresentação aos alunos desses textos e à correção daquilo que não estivesse de acordo com os modelos apresentados, em outras palavras, à correção de erros de gramática. É uma abordagem que foca o produto e não o processo, sendo, por isso, também conhecida como 'abordagem focada no produto' (em inglês, productfocused approach). Apesar de se fazer presente ainda hoje, seja na concepção de língua de alunos e professores, seja em livros e práticas pedagógicas, essa abordagem prevaleceu dos anos de 1940 até os anos de 1960 (KERN, 2000). 
A abordagem processual surgiu a partir dos trabalhos de Squire e Applebee (1969) e Emig (1971) sobre a escrita em língua materna e apresentou-se como uma reação à abordagem tradicional focada no produto. Squire e Applebee (1969) encontraram nas escolas da Inglaterra os princípios do que constituiria essa abordagem: a) incentivo à criatividade dos alunos por meio, sobretudo, da produção escrita com foco na livre expressão de idéias em oposição a exercícios artificiais de retórica; e b) instrução implícita e correções individuais por meio de conferências durante o processo de produção do texto. Emig (1971), investigando o processo de produção escrita de alunos norte-americanos, verificou como a abordagem tradicional, usada nas escolas, afetava a concepção de escrita dos alunos, limitando sua capacidade de produção e levando-os a escrever a partir de uma fórmula fixa, que impedia sua criatividade. Baseando-se nesse estudo, considerado piloto, Zamel (1982, 1983, 1985) e outros estudiosos (FERRIS, 1997; GOLSTEIN; CONRAD, 1990; SPACK, 1984) desenvolveram pesquisas com aprendizes de inglês como língua estrangeira cujos resultados contribuíram para a configuração de uma abordagem caracterizada pelas seguintes práticas: a) sugestão de temas de interesse do aluno e aplicação de estratégias de desenvolvimento e organização das idéias (anotações e produção de listas); b) conferências durante o processo de escrita (constituído pela produção de diversas versões) para solucionar problemas específicos; e c) ensino de estratégias de planejamento e pré-escrita do texto.

Pode-se dizer que a concepção de escrita, nessa abordagem, evoluiu no sentido de que passou a ser compreendida como um processo, e não mais como um produto préestabelecido, estático e independente do indivíduo. No entanto, mantém a noção de língua (e escrita) desvinculada do contexto sócio-histórico e cultural de onde surge e de que faz parte, assim como acontece na abordagem tradicional. O processo de escrita é 
entendido, nessa perspectiva, como sendo de natureza puramente cognitivista (FLOWER; HAYES, 1977, 1980, 1981). O papel do contexto seria apenas o de fornecer os temas a serem desenvolvidos pelos alunos. Assume-se que o indivíduo só precisa de um ambiente que o estimule a escrever e, nesse sentido, a tarefa do professor seria apenas a de auxiliá-lo no desenvolvimento e organização de suas idéias e em suas dificuldades específicas com a língua (KERN, 2000). Conforme explica Ferreira (2005), "o aluno é tratado como parte de um grupo homogêneo, como um ser associal cuja cognição limita-se à sua própria mente e que utiliza estratégias de composição universais" (p.19).

No final do século XX, a abordagem processual passou a receber críticas de diversas naturezas, todas (até hoje realizadas) relacionadas ao fato de não considerar os aspectos sociais, culturais e ideológicos envolvidos na escrita e em seu ensino (BIZZEL，1992; COPE; KALANTIZ，1993; DELPIT, 1988; INGHILLERI, 1989; RUSSEL, 1995; TRIMBUR, 1994). Nesse contexto, a abordagem social surge como uma resposta a essas críticas e apresenta-se em sua forma mais representativa na chamada pedagogia de gêneros textuais (doravante, gêneros). As diferentes formas de se abordar o conceito de gênero levaram, por sua vez, à formação de diferentes escolas que, segundo Hyonn (1996), estão representadas da seguinte forma: ESP (English for specific purposes), traduzido em português como 'Inglês instrumental' ou 'Língua estrangeira instrumental', representado principalmente pela obra de Swales (1990); a escola da Nova retórica, representada por autores como Coe (1994) e Freedman (1994); e a linguística sistêmico-funcional (doravante, LSF) ou escola australiana de gêneros. Neste trabalho, nos limitaremos a expor e a discutir mais detalhadamente a escola australiana de gêneros, uma vez que constitui a teoria lingüística utilizada na abordagem 
que fundamentou o curso que serviu de base para esta pesquisa, a perspectiva conceitual.

Em linhas gerais, pode-se dizer que as escolas mencionadas diferenciam-se mais pelo que priorizam no estudo do gênero, do que pela forma como o concebem. A escola da Nova retórica, por exemplo, focaliza o contexto social em que os gêneros são formados, considerando as ações implicadas na sua construção mais importantes que os discursos produzidos (HYONN, 1996; MILLER, 1984). A ESP privilegia o estudo de gêneros específicos (como os acadêmicos, por exemplo), destacando o conceito de 'comunidade discursiva', considerado fundamental na formação dos gêneros. Pode-se dizer que a definição de gênero como o propósito do texto (MARTIN, 1989), assim estabelecido pela escola australiana, está presente, de alguma forma, na concepção de gênero dessas duas outras escolas. Ao ligar o conceito de gênero ao contexto em que é produzido, essa definição, por mais simples que pareça, reflete uma concepção de língua como prática social, coerente, portanto, com a visão das demais perspectivas.

A escola australiana de gêneros textuais surgiu a partir do estabelecimento de um programa de pesquisa, desenvolvido por Martin e seus colaboradores (Frances Christie, Joan Rothery, Jennifer Hammond), em escolas australianas de ensino fundamental e médio. O objetivo do grupo era identificar os tipos de textos trabalhados pela escola e desenvolver uma pedagogia que facilitasse o seu aprendizado. Fundamentando-se na lingüística sistêmico-funcional, desenvolvida por Halliday (1978), o grupo desenvolveu uma pedagogia baseada na utilização de um modelo que guiava o professor na exploração do contexto social envolvido na produção do gênero e nos recursos que a língua disponibilizava para que o propósito do gênero fosse atingido. Esse modelo sofreu algumas alterações com base em críticas realizadas por teóricos como Freedman (1994), Lee (1996) e Luke (1996) que apontavam para a necessidade de 
uma abordagem mais crítica e que preparasse melhor os alunos para interagirem em sociedade.

A terceira versão desse modelo, representado na figura 1, é constituído por três fases: desconstrução, construção conjunta e construção independente.

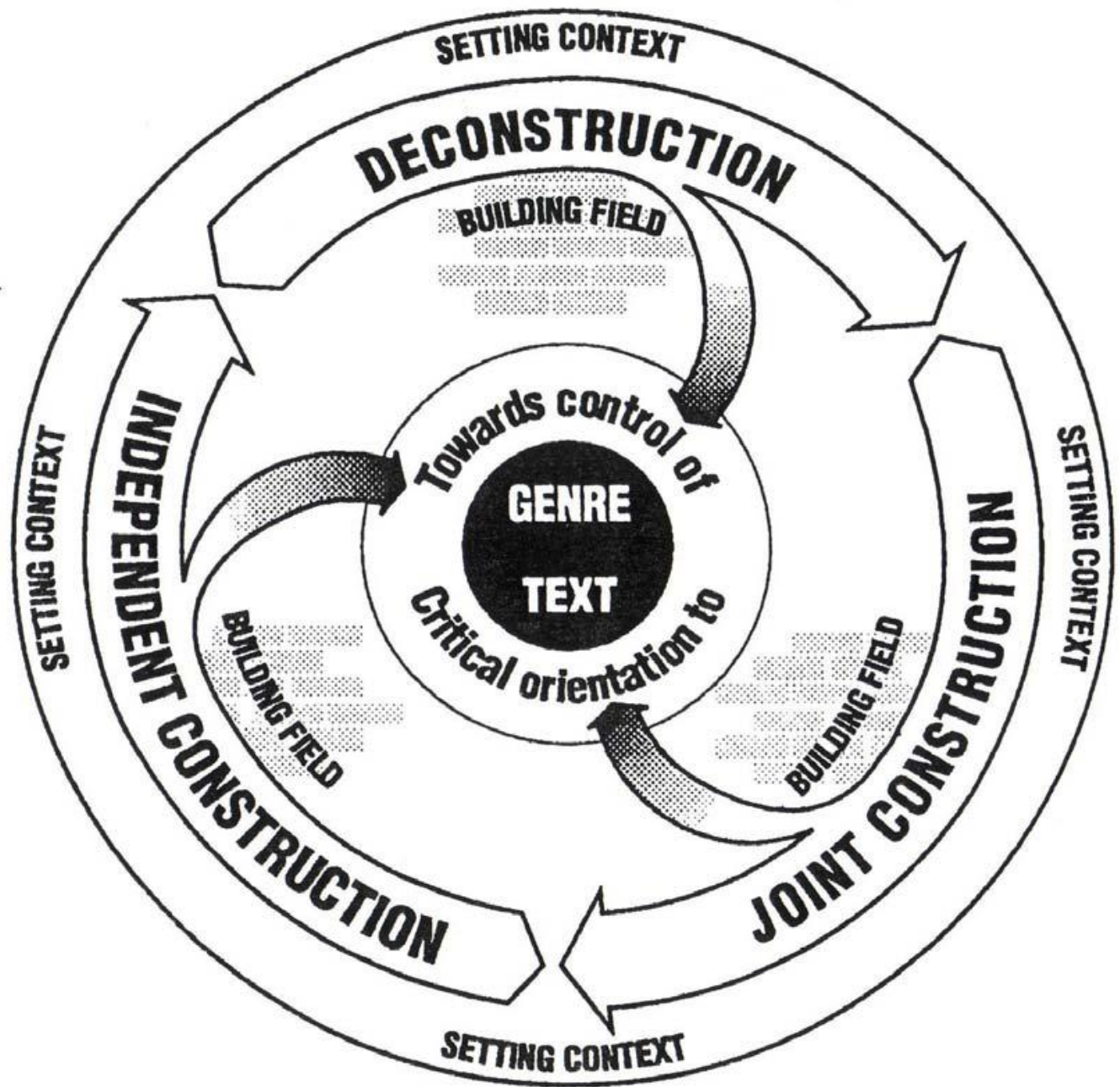

Figura 1: Modelo curricular versão 3 (Rothery \& Stenglin, 1994, p.8) 
Na primeira fase, focaliza-se o contexto social em que se insere o gênero e em como a língua é utilizada para atingir seu propósito. O professor expõe os alunos a amostras de um determinado gênero e tenta eliciar deles o contexto em que foi produzido. Em seguida, realiza uma instrução explícita sobre esse contexto e sobre como o propósito do gênero é alcançado por meio da língua em termos de estágios desse gênero (estrutura retórica), gramática e léxico. Na segunda fase, os alunos produzem o texto, colaborativamente, com o professor. $\mathrm{Na}$ terceira e última fase, produzem o seu próprio texto, de forma independente. Em todas estas fases, no entanto, o contexto social do gênero é abordado.

O modelo construído por Martin para guiar o ensino da escrita por meio de gêneros fundamentou-se, como já mencionado, na teoria lingüística desenvolvida por Halliday (1978). Ao modelo de Halliday, constituído pelas variáveis ‘campo', 'relação’ e 'modo', constituintes do contexto situacional (registro), Martin (1993) acrescentou o contexto da cultura (gênero), respondendo, dessa forma, às críticas citadas. A noção de ideologia também está presente em seu modelo, conforme mostra a figura 2: 


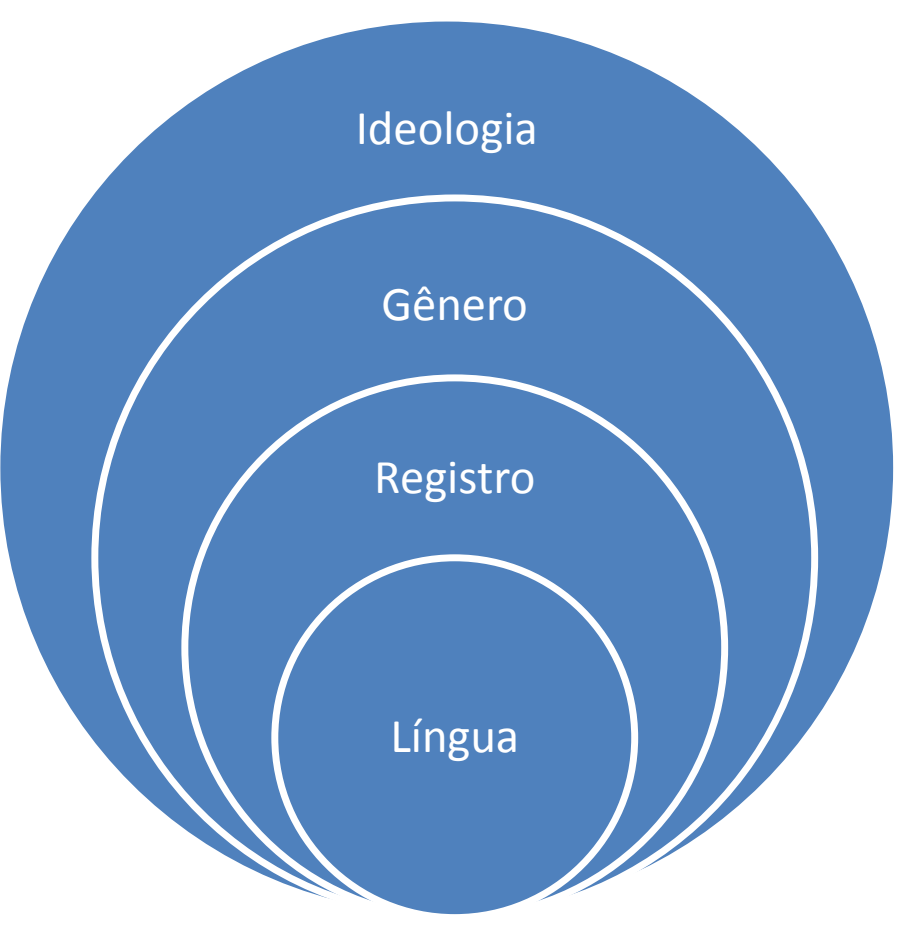

Figura 2: Língua em relação ao registro, gênero e ideologia (Martin, 1993, p.158)

O registro, entendido como o contexto situacional, é constituído pelas variáveis 'campo', 'relação' e 'modo'. Esses elementos do contexto situacional serão influenciados pelo contexto da cultura, que constitui o gênero. A variável 'campo' diz respeito à ação social, à atividade em que os interlocutores estão engajados, que remeterá ao conteúdo do texto; a variável 'relação' refere-se aos interlocutores e à relação entre eles; e 'modo' refere-se ao papel que a língua está desempenhando em relação aos demais elementos do contexto, ao que os interlocutores esperam que a língua realize, mas também a própria organização do texto e o canal utilizado (MARTIN, 1993). Em síntese, a cultura, considerada um dos elementos do contexto, influencia o registro (contexto situacional) que, por sua vez, determinará as escolhas lingüísticas realizadas pelo escritor. 
Como é possível perceber, essa abordagem apresenta uma teoria lingüística clara e sólida, fundamentada na relação dialética entre língua e contexto social, sendo, dessa forma, capaz de fundamentar pedagogias que visem à capacitação sócio-linguística de aprendizes de língua estrangeira por meio da instrução explícita, como é o caso da perspectiva conceitual.

Apesar de trabalhar com gêneros específicos ligados ao contexto escolar (fato a que deve a maior parte das críticas recebidas, mas que pode ser explicado pelos objetivos que lhe deram origem), Ferreira (2005) acredita que é possível, por meio dessa abordagem, capacitar os alunos para uma interação mais efetiva em sociedade a partir de uma instrução explícita e crítica que leve à transformação dos gêneros ensinados (p.31). Além disso, segundo a autora, a linguística sistêmico-funcional permite abordar um aspecto do processo de ensino-aprendizado da escrita, pouco explorado, mas fundamental do ponto de vista da perspectiva sócio-histórico-cultural: o desenvolvimento cognitivo dos alunos.

Em sua abordagem para o ensino da escrita em língua estrangeira, Ferreira (2005) utiliza os princípios da pedagogia desenvolvida por Davydov (1999) com o objetivo de promover um ensino que conduza ao desenvolvimento Vygotsky (1978). O aspecto do desenvolvimento focalizado em sua perspectiva refere-se ao pensamento teórico dos alunos. Davydov (1999) acredita na necessidade de se priorizar, na Educação, esse tipo de pensamento em relação ao pensamento empírico. Conforme explica Ferreira (2005), o pensamento empírico busca compreender os objetos e os fenômenos do mundo a partir de suas características superficiais, captadas pelos órgãos dos sentidos. Esse tipo de pensamento, portanto, não apenas leva a uma compreensão superficial desses objetos e fenômenos, mas pode, muitas vezes, levar a uma visão distorcida da realidade. A perspectiva conceitual surge, dessa forma, não como uma 
resposta às críticas feitas à escola australiana, mas, partindo dela, objetiva focalizar um aspecto específico dentro do processo de ensino-aprendizado que é o desenvolvimento cognitivo dos alunos sob a forma de pensamento teórico capaz de levar, por sua vez, ao desenvolvimento do seu pensamento crítico.

\subsection{A perspectiva conceitual}

Conforme vimos, a perspectiva conceitual (FERREIRA, 2005) constitui uma abordagem relativamente nova para o ensino da escrita em língua estrangeira, que alia a escola australiana de gêneros textuais (MARTIN, 1989, 1993, 1999) à pedagogia davydoviana (DAVYDOV, 1999), ainda não explorada nesse texto. Nesse ponto, portanto, faremos uma breve apresentação dos princípios da pedagogia davydoviana e, em seguida, explicaremos como ela relaciona-se à escola australiana na constituição da perspectiva conceitual.

\subsubsection{A pedagogia davydoviana}

A pedagogia davydoviana fundamenta-se na perspectiva sócio-histórico-cultural e na teoria da atividade, uma perspectiva psicológica desenvolvida por Leontiev (1981) a partir dos trabalhos de Vygotsky $(1978,1987)$ e de filósofos como Hegel e Marx (WERTSCH, 1981). Leontiev (1981) considera o conceito de atividade (tal como concebido por Hegel e Marx) o princípio explicativo básico do desenvolvimento humano (em outras palavras, o elemento responsável pela formação da consciência humana) ampliando e aprofundando, dessa forma, a teoria vygotskiana ${ }^{1}$. 
Conforme explica Ferreira (2005), da perspectiva sócio-histórico-cultural, Davydov adota a metodologia genética e o princípio de que o aprendizado leva ao desenvolvimento. Da teoria da atividade, por sua vez, ele adota o princípio de que a consciência é resultado da atividade prática do homem no mundo. Para entendermos como Davydov se apropria desse princípio é fundamental conhecermos como o conceito de atividade é compreendido nessa teoria.

O conceito de atividade é visto sob duas dimensões (que, conforme explica Leontiev (1981), devem ser compreendidas como partes, dialeticamente integradas, de um mesmo sistema): a dimensão prática, que corresponde à atividade prática do indivíduo no mundo; e a dimensão teórica, que corresponde à sua atividade mental. Kant foi o primeiro filósofo a reconhecer a dimensão prática da atividade. Fichte, por sua vez, estabeleceu a primazia desta em relação à sua dimensão teórica, considerando o conteúdo da mente proveniente da ação dialética do indivíduo no mundo. Elaborando esses princípios, Hegel postula ser a atividade social (o trabalho) responsável pela constituição da consciência. Marx, em seu estudo sobre o capitalismo, comprova a afirmação de Hegel, demonstrando a natureza essencialmente prática e social da atividade humana (FERREIRA, 2005).

Fundamentando-se nesse conceito de atividade, Leontiev (1981) aprimora o princípio da mediação por meio de instrumentos simbólicos, desenvolvido por Vygotsky, e elege a atividade como a unidade básica de análise em sua teoria. Nas palavras de Lompscher (2002), dentro dessa perspectiva, a atividade é definida como "a forma específica e fundamentalmente humana de relacionamento entre os seres humanos e o mundo" (p. 80). 
Em sua análise da atividade, Leontiev (1981) a divide em três componentes: motivos, ações e operações. Para ele, toda atividade origina-se a partir de um 'motivo', que pode ser entendido como uma necessidade, determinada física e socialmente, que leva, por sua vez, à busca por um objetivo (ou, em outras palavras, à solução de um problema). As 'ações' correspondem à realização da atividade. As 'operações' referemse às condições em que as ações são realizadas (ou, em outras palavras, aos meios utilizados para sua realização). É interessante notar, conforme explica Leontiev (1981), que ações semelhantes podem estar relacionadas a atividades completamente diferentes, se os motivos que lhes dão origem forem distintos. Como forma de ilustrar esse princípio, podemos pensar na seguinte situação: uma professora determinando um conjunto de ações para os seus alunos, baseada em um motivo específico, não compartilhado por eles. Nessa situação, entende-se que estejam sendo realizadas ações semelhantes, mas, provavelmente, pertencentes a atividades distintas (porque relacionadas a diferentes motivos), levando, dessa forma, a diferentes resultados.

O conceito de atividade, tal como adotado por Davydov a partir dessa perspectiva, foi ainda um pouco mais elaborado por Galperin (1992), que procurou focalizar o papel do indivíduo nesse processo (HAENEN, 1996). Para ele, o objeto da psicologia deveria constituir a atividade orientada, definida como "a orientação do indivíduo (em relação às ações que realiza) em situações-problemas” (p.68). O conceito de ação, desenvolvido por Leontiev (1981), é elaborado por Galperin (1966), que o divide em outros três componentes: orientação (planejamento da ação), execução (realização da ação) e controle (verificação da ação). Para ele, a orientação constitui a base da ação, a unidade dialética que liga a atividade prática à atividade mental. Do ponto de vista da sua teoria, o processo de conversão das ações práticas em ações mentais, denominada internalização, organiza-se da seguinte forma: ação concreta - fala 
social - fala privada - fala interna - pensamento. Conforme explica Ferreira (2005), Galperin dedicou sua vida à investigação das atividades orientadas de alunos, durante a utilização de cartões de orientação criados por ele. Os alunos aplicavam as orientações contidas nos cartões às diferentes situações-problemas apresentadas. Galperin acreditava que as capacidades mentais pudessem ser "intencional e diretamente desenvolvidas” (p. 43). Sua pedagogia ficou conhecida como 'a formação sistemática de ações (mentais) e conceitos'.

Baseando-se na concepção de 'atividade orientada' elaborada por Galperin, Davydov (1999) procura focalizar seu caráter transformador, definindo-a como "uma forma específica de existência social dos seres humanos que consiste na mudança propositada das realidades natural e social" (p. 39). Nesse sentido, seu objetivo era desenvolver uma pedagogia em que o indivíduo pudesse agir de maneira consciente e transformadora em sociedade. Para isso, utilizando os princípios da dialética e baseando-se no estudo de Vygotsky (1987) sobre a formação de conceitos científicos e nos princípios gerais da teoria sócio-histórico-cultural, Davydov implementa o que constituía a proposta de Hegel para a educação: a promoção do pensamento teórico do aluno. Em sua pedagogia, o pensamento teórico constitui a orientação da atividade, aprimorando, dessa forma, a perspectiva galperiniana, em que o conhecimento era oferecido pronto aos alunos por meio dos cartões de orientação.

O pensamento teórico é considerado o foco da pedagogia davydoviana - e a orientação da atividade - por ser considerado o tipo de pensamento mais adequado para a compreensão da realidade, em oposição ao pensamento empírico (DAVYDOV, 1984). Segundo explica Lompscher (1984), o pensamento teórico fundamenta-se na lógica dialética que, em oposição à lógica formal (em que se baseia o pensamento empírico), procura compreender os fenômenos historicamente (em seu processo de formação e 
mudança) com o objetivo de revelar sua gênese (origem) e relações essenciais. De acordo com Davydov (1984), o pensamento empírico pode levar à construção de ‘falsos' conceitos (ou 'complexos', assim definidos por Vygotsky (1987), uma vez que se baseia nas características superficiais dos objetos a partir de observações orientadas pela percepção sensorial. Davydov (1984) chama atenção para o fato de que a forma como o universal (as leis essenciais, o abstrato) está presente no particular (em sua manifestação concreta, no concreto) pode não corresponder à forma como o particular se manifesta, podendo, por isso, levar a uma compreensão errada desse objeto.

É importante enfatizar, também, que o concreto e o abstrato são concebidos de maneira diferente pela lógica formal e pela lógica dialética. A lógica formal, baseada no empiricismo (no pensamento empírico), considera o 'concreto' como o objeto particular percebido pelos órgãos do sentido; e o 'abstrato', a sua forma geral, suas características repetidas, definidas em classes ou categorias (ILYENKOV, 1982). A lógica dialética, por sua vez, em que se baseia o pensamento teórico, entende o concreto como uma manifestação do abstrato, considerado a essência do objeto, suas relações internas, suas leis essenciais, sua base universal. Para serem adequadamente compreendidos é necessário que tanto o concreto como o abstrato sejam interpretados a partir de um pensamento teórico em detrimento do empírico, ou seja, de maneira dialética e não empírica.

Conforme explica Lompscher (1984), do ponto de vista da lógica dialética, o concreto não é compreendido como "um elemento isolado", mas como "uma unidade de características específicas, singulares e gerais, como uma unidade constituída de muitos e diferentes aspectos, características e relações, enfim, como um sistema” (p. 294). Dessa forma, "a formação do pensamento teórico começa (...) no nível empírico” (p. 
333), pois o abstrato só pode ser encontrado no concreto, no entanto, por meio do pensamento teórico e não empírico.

Em sua análise da formação dos conceitos científicos, Vygotsky chama de 'complexos' os conceitos formados a partir do pensamento empírico, que corresponderia ao tipo de pensamento apresentado pelas crianças. Por outro lado, chama de conceitos científicos, os conceitos formados a partir do pensamento teórico. Enquanto os complexos expressam características superficiais dos objetos, os conceitos científicos expressam sua essência, as relações essenciais presentes no objeto, que só podem ser reveladas por meio da observação do concreto em seu processo de desenvolvimento, em sua origem, em suas relações com outros objetos, em seu processo de mudança, em seus conflitos e contradições (ACTON, 1967). Segundo Vygotsky, toda disciplina (área de conhecimento) é formada por conceitos essenciais que a explicam. Para ele, os conceitos, assim como todo sistema de símbolos, servem como instrumento psicológico (mediação) para a solução de problemas (na interação entre indivíduo e sociedade).

Fundamentando-se, como mencionado, na análise de Vygotsky (1987) sobre a formação dos conceitos científicos e em sua noção de conceito como instrumento psicológico, Davydov procura, em sua pedagogia, desenvolver o pensamento teórico dos alunos por meio do ensino de conceitos científicos considerados essenciais em uma disciplina. A partir da busca pelas relações básicas em um objeto (ou seja, do universal, do abstrato), no processo de formação dos conceitos científicos, o pensamento teórico do aluno estaria sendo desenvolvido. Os conceitos científicos desenvolvidos serviriam, por sua vez, como instrumentos psicológicos para a solução de problemas envolvendo uma área específica do conhecimento. Pensamento teórico é, dessa forma, 
compreendido como pensamento dialético usado para a formação de conceitos científicos.

Essa busca pelo abstrato, que resulta no desenvolvimento do pensamento teórico dos alunos (seguindo, portanto, um movimento que parte do abstrato para o concreto), é implementada, na pedagogia davydoviana (também conhecida como 'movimento do abstrato para o concreto' (doravante, MAC)) por meio da condução pelo professor de um processo de quase-investigação científica, que reproduz de maneira compactada uma investigação científica real. Conforme explica Ferreira (2005, p.54), o objetivo é levar os alunos a descobrirem a origem do conhecimento que estão adquirindo (na verdade, construindo), tornando-os aprendizes mais ativos, mais autônomos e conscientes do seu próprio processo de aprendizagem. As relações essenciais que se vão descobrindo (em outras palavras, o conhecimento que vai sendo construído) a partir desse processo são expressas por meio de modelos chamados germ-cell que consistem em representações visuais dos elementos constituintes do objeto e de suas relações essenciais. $\mathrm{O}$ objetivo é que esse modelo seja um instrumento para o desenvolvimento do pensamento teórico, da produção do conhecimento abstrato/dialético da disciplina envolvida e que possa, posteriormente, ser aplicado para a solução de problemas, bem como orientar a instrução. Tanto o modo como o ensino é conduzido (por meio de uma quase-investigação científica), como a produção, modificação e aplicação desses modelos, levam ao desenvolvimento das capacidades de auto-controle e auto-avaliação do aluno em relação ao seu processo de aprendizado.

O primeiro passo a ser seguido na pedagogia davydoviana, no entanto, é estabelecer uma situação-problema em que os alunos percebam a necessidade do conhecimento a ser ensinado. Em outras palavras, a aprendizagem deve constituir uma atividade em si e não um meio para se alcançar algo (por exemplo, para tirar nota ou 
passar em um exame). A atividade de aprendizagem deve ser constituída por ações orientadas por um motivo que seja a necessidade de se aprender o conteúdo a ser ensinado. Para que isso ocorra, ela deve estar ligada à atividade principal (em inglês, leading activity) desenvolvida pelo indivíduo em sociedade (no caso dos adultos, à sua profissão).

Sistematizando, com o objetivo de levar os alunos a identificarem o abstrato (as relações essenciais de um objeto, de uma disciplina) ou, em outras palavras, de os levarem do abstrato ao concreto, Davydov estabelece uma série de ações que compõem a atividade de aprendizagem. São elas: situação-problema, produção de modelo, modificação de modelo, aplicação de modelo, controle e avaliação.

\subsubsection{SFL e a pedagogia davydoviana: a constituição da perspectiva conceitual}

Na perspectiva conceitual, o componente abstrato a ser ensinado corresponde à forma como a língua é compreendida pela linguística sistêmico-funcional, ou seja, à relação dialética língua-contexto. Esse componente abstrato, chamado de princípio comunicativo abstrato (doravante, PCA), corresponde à essência da língua e foi representado por Ferreira (2005) em um modelo germ-cell construído a partir dos modelos linguísticos desenvolvidos pela linguística sistêmico-funcional. 


\section{CULTURA}

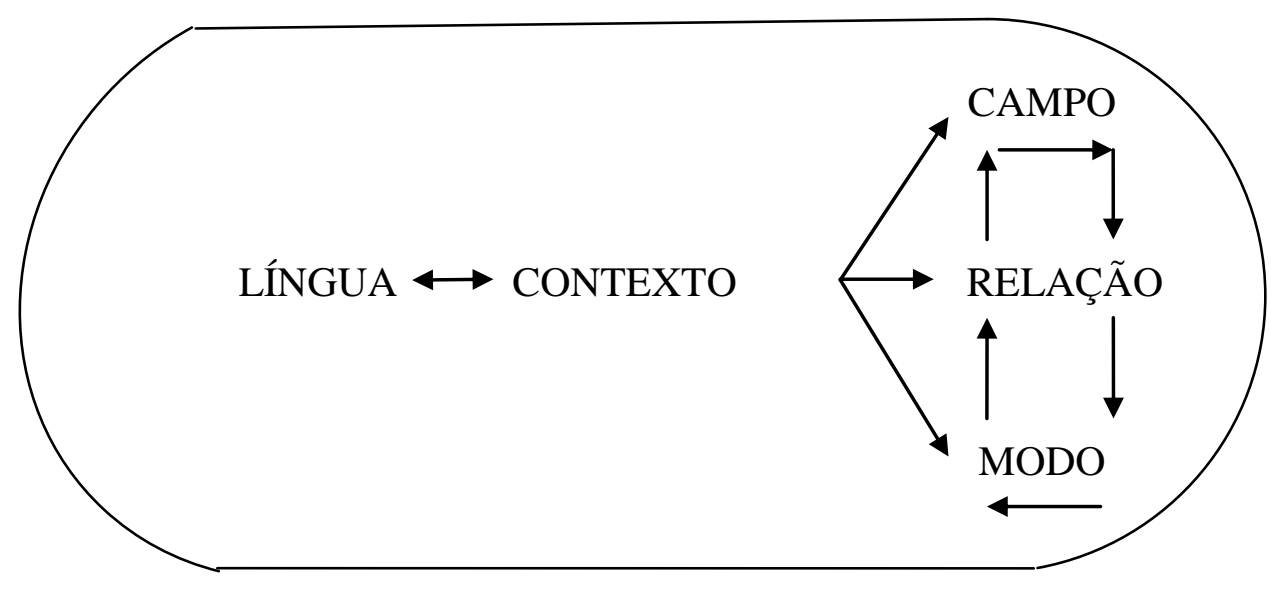

Figura 1. Modelo germ-cell (versão final) (Ferreira, 2005, p.79).

Como vimos, os modelos germ-cell têm a dupla função de promover o pensamento teórico dos alunos e, ao mesmo tempo, orientar a instrução. Nesse modelo são identificados os elementos do contexto bem como as relações entre eles. $\mathrm{Na}$ perspectiva conceitual, o principal conceito a ser ensinado é o conceito de gênero textual tal como concebido pela escola australiana de gêneros (ou seja, como o propósito do texto, representado pelo contexto da cultura). Esse conceito, no entanto, deve ser ensinado como conceito científico, ou seja, como representativo da relação dialética entre o elemento concreto (ou seja, os textos escritos de um modo geral) e o abstrato (ou seja, o PCA). Compreendido dessa forma, o conceito de gênero funciona, conforme vimos, como ferramenta psicológica para a solução de problemas, nesse caso, para a escrita efetiva de textos.

Os gêneros escolhidos para serem trabalhados em aula, e que são utilizados para levarem os alunos do abstrato para o concreto e vice-versa, devem estar ligados à sua 
leading activity, que também deverá ser levada em consideração durante a realização da primeira ação de aprendizagem, a situação-problema.

A situação-problema, que tem a função de levar o aluno a perceber a necessidade do conteúdo a ser ensinado, ligando a atividade de aprendizagem à sua leading activity, é implementada, na perspectiva conceitual, por meio de questõesproblemas. Ferreira (2005) desenvolve a seguinte questão-problema geral com base na visão de língua da escola australiana:

"We use language in a variety of situations and to achieve a wide range of goals. How do we use language to achieve these goals? How does the social situation affect our use of language?" (p. 75)

Conforme explica Ferreira (2005), “as questões focalizam o PCA, ou seja, a relação língua-contexto, e como o conhecimento dessa relação pode ajudar os alunos a aprender e a usar a língua de modo efetivo" (p. 75).

Os modelos produzidos a partir da perspectiva conceitual devem representar o PCA e podem ser apresentados aos alunos (que também devem construir os seus próprios modelos) em diferentes versões, à medida que os elementos do PCA vão sendo explorados a partir do MAC (o que corresponde à segunda ação). Dessa forma, uma primeira versão desse modelo pode ser representada da seguinte forma (onde representa o conflito, a tensão na relação dialética língua-contexto):

\section{LÍNGUA $\longleftarrow$ EONTEXTO}

Figura 2: modelo germ-cell versão 1 (Ferreira, 2005, p. 79)

A modificação dos modelos por parte dos alunos (a terceira ação de aprendizagem) deve ser realizada durante o processo de ensino a partir do MAC, por 
exemplo, antes e após o contato com amostras concretas dos gêneros trabalhados. Simultaneamente, exercícios como a produção de textos e análises linguísticas devem ser aplicados de modo que os modelos produzidos sirvam de instrumento para sua realização (o que corresponde à quarta ação).

As ações de controle e avaliação (quinta e sexta ações) são realizadas a partir da aplicação de questões de auto-controle, manutenção de diários, relatórios etc. As capacidades de controle e avaliação também podem ser desenvolvidas por meio da verbalização (por exemplo, da explicação dos alunos dos seus modelos (HEDEGAARD, 1990)) e uso do modelo de procedimento científico, que indica ao aluno os passos a seguir no seu processo de aprendizagem. A verbalização exige reflexão e, portanto, avaliação do conhecimento construído e controle das suas ações (LOMPSCHER, 1999). Além disso, conforme enfatiza Ferreira, a "verbalização é fundamental para que a internalização ocorra" (p.85).

A sétima ação, interação, constitui uma característica fundamental da perspectiva davydoviana, considerando-se, conforme mostra Vygotsky, que o desenvolvimento cognitivo humano ocorre na interação entre os indivíduos em sociedade, mediada pela linguagem. Os alunos podem interagir em pares ou em grupo por meio de discussões ou da realização de exercícios em geral como a produção conjunta de textos, análises linguísticas etc.

Os exercícios de leitura e as análises linguísticas correspondem a um aspecto fundamental no processo de aprendizado da escrita nessa perspectiva. São as leituras das amostras dos gêneros e sua análise a partir de uma perspectiva dialética que levarão ao aprendizado do PCA. Por meio das análises linguísticas, são ensinados os conceitos de campo, relação, modo e movimentos (que correspondem à forma como os textos são organizados). A leitura de textos teóricos também é realizada e tem a função de 
promover discussões e prover informação a respeito das características empíricas presentes nas amostras de gêneros, contribuindo dessa forma para a dinâmica do movimento abstrato concreto e vice-versa.

Nesse processo, as conferências com os alunos (onde praticamente todos os aspectos envolvidos no processo de aprendizagem são tratados) e a produção de múltiplas versões, características próprias da abordagem processual, constituem uma parte relevante no desenvolvimento das habilidades de escrita dos alunos.

Conforme explica Ferreira (2005, p. 88), nessa perspectiva, os alunos são levados a "ver gênero como um conceito lingüístico (científico) presente em suas vidas e como uma ferramenta necessária para uma comunicação efetiva" (p. 88). O ensino do gênero como conceito científico, realizado a partir do ensino do princípio comunicativo abstrato do qual se origina, objetiva, conforme explica Lompscher (1984), desenvolver no aluno a capacidade de se "posicionar de maneira ativa em relação ao conhecimento, o que significa ser capaz de prever e transformar o seu objeto de aprendizagem" (p. 331), em outras palavras, espera-se que os alunos "sejam capazes de aplicar essa abstração [...] como um meio [...] para a análise e a explicação cada vez mais independente dos fenômenos que constituem a realidade" (p.334).

\subsection{Sobre o curso}

\subsubsection{Informações gerais}

O curso, intitulado "Praticando a escrita em inglês por meio de gêneros textuais: a argumentação", foi oferecido como curso de extensão a interessados em geral, com nível intermediário de inglês, em uma universidade pública do estado de São Paulo. O curso foi ministrado aos sábados, das 10h às 13h, de 18/09/2010 à 11/12/2010, 
totalizando uma carga horária de vinte e sete horas (nove aulas de três horas de duração cada).

O nível de proficiência dos alunos foi avaliado a partir de um teste elaborado pela instrutora com base no Toefl. Esse teste incluiu também uma questão dissertativa que objetivou antecipar a qualidade da produção escrita dos alunos e, ao mesmo tempo, investigar seus objetivos em relação ao curso (ver anexo A - exame de proficiência).

De um total de dezoito alunos matriculados, oito freqüentaram a maior parte das aulas e foram aprovados, dez não atingiram a freqüência mínima necessária para obter aprovação.

Considerou-se como critério de avaliação para aprovação no curso a frequiência mínima (85\%), estipulada pelo departamento de cultura e extensão da universidade, e a participação dos alunos nas atividades realizadas em aula (discussões, atividades em grupo, produção de textos e representações visuais do conceito de gênero) e extraclasse (respostas às questões do diário dialogado e da ficha de identificação).

O curso "Praticando a escrita em inglês por meio de gêneros textuais: a argumentação" foi fundamentado na perspectiva conceitual (FERREIRA, 2005). Coerentemente com essa abordagem, objetivou promover o pensamento teórico dos alunos por meio da aplicação das ações de aprendizagem propostas por Davydov (1999).

O estudo do texto argumentativo foi baseado em Hyland (1990). O autor explica como o texto é organizado em função do propósito do gênero, coerente, portanto, com a perspectiva linguística adotada no curso. Ele descreve o texto argumentativo em termos de "estágios" e "movimentos". 
Os estágios correspondem aos princípios de organização do gênero. São eles: tese, argumentação e conclusão. Cada estágio é composto por movimentos, alguns obrigatórios, outros opcionais. Os movimentos organizam, por sua vez, os estágios e são concretizados no nível da forma pela língua (léxico e gramática).

Nessa perspectiva, o texto argumentativo é definido pelo seu propósito que é o de persuadir o leitor a respeito de uma proposição. A tese introduz o tema e apresenta a proposição a ser defendida. A argumentação apresenta as razões que caracterizam o gênero. A conclusão não é um resumo ou uma revisão, mas uma fusão dos elementos constituintes do gênero, servindo para consolidar o discurso por ele construído.

A Tese (Thesis) pode apresentar até cinco movimentos, dos quais apenas um é obrigatório: a proposição (The proposition). Os outros quatro são: chamar atenção do leitor (Gambit); contextualizar o tema/fornecer informações (Information); dar suporte à proposição (Evaluation); e introduzir e/ou identificar uma lista (Marker).

No estágio da argumentação (Argument), um ciclo de quatro movimentos podem se repetir indefinidamente. No entanto, um não é obrigatório: repetir a proposição (Restatement). Os demais são: sinalizar a introdução da afirmação que sustentará a proposição (Marker); realizar uma afirmação que sustente a proposição (Claim); realizar uma afirmação que sustente a afirmação que, por sua vez, sustenta a proposição (Support).

A Conclusão (Conclusion) é composta por quatro possíveis movimentos, sendo apenas um obrigatório: relacionar o conteúdo da argumentação com a proposição (Consolidation). Os demais são: sinalizar a introdução da conclusão (Marker); reformular a proposição (Affirmation); amplia o contexto ou a perspectiva da proposição (Close). 
A tabela, abaixo, facilita a compreensão dessa descrição ao informar a sequência em que podem aparecer (os movimentos obrigatórios estão em negrito):

\begin{tabular}{|l|l|}
\hline Estágio & Movimentos \\
\hline Tese & Proposition \\
& Gambit \\
& Information \\
& Evaluation \\
\hline Argumentos/Argumentação & Marker \\
\hline Conclusão & Marker \\
& Close \\
& Restatement \\
\hline & Claim \\
\hline & Support \\
\hline
\end{tabular}

\subsubsection{Descrição das ações pedagógicas do curso}

\section{Exame de Proficiênca}


Com o objetivo de avaliar o nível de proficiência dos alunos, a instrutora elaborou um teste, semelhante ao Toefl, que incluiu questões de gramática, leitura e escrita. A questão dissertativa, especificamente, visou identificar a qualidade da produção escrita dos alunos e suas motivações em relação ao curso:

Why do you think this course is important for you?

How do you relate it to your personal or professional experience?

Which goals do you expect to achieve through it?

Como ação pedagógica, essas questões visaram desenvolver o auto-controle dos alunos em relação ao seu processo de aprendizagem. Ao refletirem sobre o conhecimento que esperavam adquirir e sobre como ele poderia ser útil às suas atividades práticas no mundo, os alunos estariam desenvolvendo a capacidade de controlarem o seu próprio processo de aprendizagem e, ao mesmo tempo, estariam ligando o conteúdo a ser ensinado às atividades em que estão engajados (à sua leading activity).

\section{Aula 1}

No primeiro dia de aula, após terem sido informados da pesquisa e terem sido esclarecidos sobre sua participação e assinado o documento de consentimento, os alunos tiveram a oportunidade de se apresentarem e explicarem (mais uma vez, agora, oralmente e para o grupo) os motivos que os levaram a se matricular no curso. Além do que já haviam exposto no exame de proficiência, durante as apresentações foram levantadas questões como: 
"Por que a atividade de leitura não é suficiente para promover as habilidades de escrita? Por que saber gramática é fundamental, porém não é suficiente? Que parâmetros utilizar para saber se estamos escrevendo um bom texto?"

Após o intervalo, os alunos realizaram um teste diagnóstico que serviria como pré-teste para avaliar seu desempenho na produção de textos argumentativos. Após essa aula, eles responderam a questões de auto-controle e preencheram uma Ficha de Identificação (ver anexo B - Ficha de Identificação) com perguntas que visavam compreender suas concepções de língua e escrita:

Questões de auto-controle realizadas após a realização do pré-teste:

Como você se sentiu quando a instrutora disse que após o intervalo vocês fariam uma atividade de produção textual em forma de teste? Como você se sente quando tem que escrever em inglês? E na sua língua materna? Qual a diferença?

Como foi durante o processo de escrita do texto? O que você fez primeiro? Você usou a folha de rascunhos? Para quê, exatamente: para anotar suas idéias ou para escrever o texto e depois corrigi-lo?

Quais foram as suas principais dificuldades na hora de escrever (organizar as idéias, definir uma opinião em relação ao assunto do texto, falta de vocabulário, falta de conhecimento gramatical para desenvolver as idéias etc)?

Perguntas da Ficha de Identificação:

Você tem dificuldades em escrever em inglês? Se sim, quais são elas?

Em que ocasiões você já escreveu (ou escreve) em inglês e com que freqüência?

Por que você se inscreveu neste curso? O que você espera que ele te proporcione? 
A aplicação dessas questões, que colocou mais uma vez em prática a ação A5 davydoviana, tinha o objetivo de fazê-los refletir sobre suas reais necessidades em relação à escrita, uma vez que agora estavam pensando a partir de uma experiência recente de produção textual. Tinha, também, como objetivo prepará-los para pensar em como poderiam solucionar esse problema.

\section{Aula 2}

No segundo dia de aula, a instrutora sugeriu alguns materiais de apoio como gramáticas, dicionários e manuais, apresentando-os apenas como ferramentas para eventuais consultas e não como fonte de conhecimento fundamental para o aprendizado da escrita.

Após o intervalo, os alunos assistiram ao filme "Freedom Writers" que explorou o uso autêntico da escrita e seu papel na vida de jovens que conseguiram, por meio dela, dar sentido às suas vidas. Como tarefa de casa, foi solicitada a leitura de Lima (2008) e Foley (1989)

O texto da Foley faz uma crítica ao uso do modelo Five-paragraph como única referência para o ensino de escrita. O texto de Lima sobre collocations consistiu em mais um material de apoio.

A forma como os materiais foram abordados, bem como as leituras propostas e a apresentação do filme tiveram como objetivo levar os alunos a refletirem sobre a língua de uma perspectiva diferente da que demonstraram ter em suas respostas às questões levantadas e às perguntas elaboradas até então, em outras palavras, a ver a escrita de um modo mais significativo, não como um fim em si mesma.

\section{Aula 3}


No terceiro dia de aula, com o objetivo de colocá-los em uma situação-problema que os conduzisse à busca pelo conhecimento do $A C P$, da relação língua-contexto, a instrutora, propôs a seguinte atividade em grupo:

1. Make a list in order of importance of what you consider fundamental to produce a satisfactory piece of writing.

2. Explain the importance of each item mentioned.

A intenção era fazê-los refletir sobre suas reais necessidades em relação à escrita. Foi unânime dizer que o conhecimento da língua estava em primeiro lugar. Todavia, esse conhecimento eles tinham. O que faltava então? Que conhecimento precisavam adquirir para melhorar sua produção escrita em inglês? Essa constituiu sua primeira questão-problema.

Nesse ponto, a instrutora introduziu-lhes o "Scientific Work Board" (SWB) e explicou-lhes que, sendo a língua o seu objeto de estudo, eles iriam investigá-la para compreendê-la e chegar à resposta do seu problema.

Esta reflexão iniciou-se a partir do filme, que abordou a escrita como parte da vida de quem escreve, ou seja, relacionada à atividade psíquica e social, e do texto da Foley que critica a escrita artificial por meio da imitação de modelos, mais grave do que isso, de um único modelo, o "Five-paragraph essay".

\section{Aula 4}

Na quarta aula, quando os alunos já haviam sido introduzidos ao SWB e tinham uma questão-problema (que conhecimento precisavam adquirir para melhorar sua produção escrita em inglês?) para responder, a instrutora conduziu uma reflexão sobre a gênese da linguagem. O objetivo era levá-los a perceber que a língua está diretamente 
relacionada à "atividade", às ações do ser humano, sendo usada como ferramenta psicológica na solução de problemas. Foi utilizado o típico exemplo vygotskiano do gesto de apontar.

Dessa forma, chegou-se a questão da relação entre língua e contexto (campo, relação, modo e cultura) e, portanto, a uma nova questão-problema (A1) que conduziria diretamente ao ensino do $A C P$ :

We use language in a variety of situations and to achieve a wide range of goals.

How do we use language to achieve these goals? How does the social situation affect our use of language?

O ensino da relação língua-contexto foi conduzido com base no seguinte modelo representativo das relações entre os seus elementos e por isso chamado modelo "germcell':

\section{CULTURE}

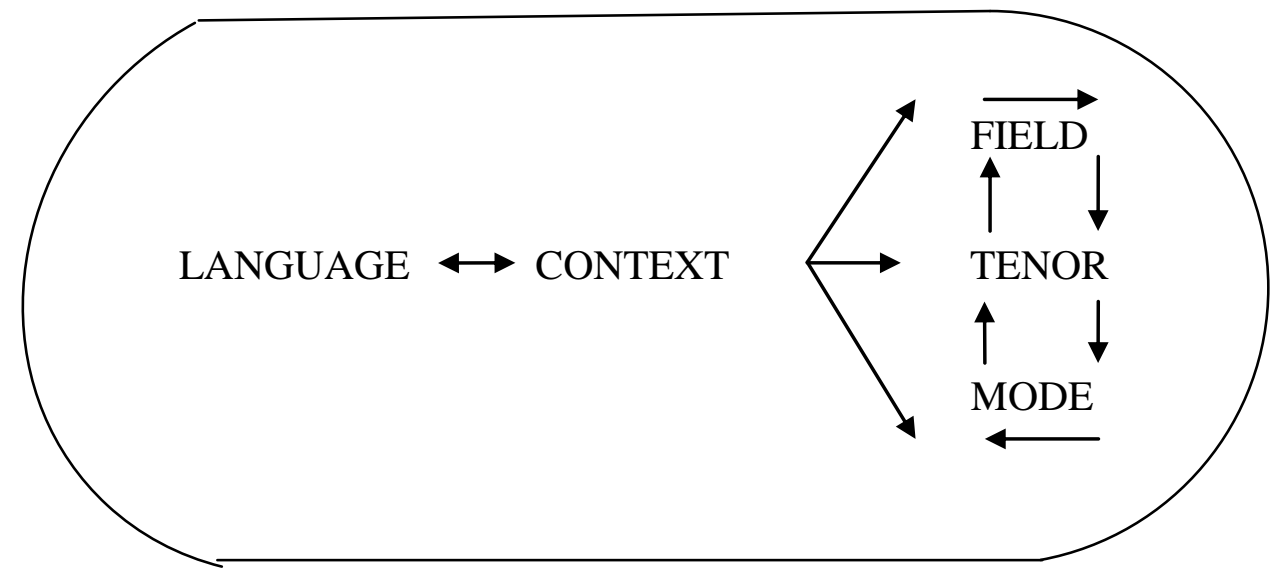

Colocada a segunda questão-problema e iniciada uma investigação, segundo o SWB, do objeto de investigação do curso (a língua), os alunos foram questionados sobre 
os possíveis caminhos para respondê-la. A resposta unânime foi a leitura. Dentro desse contexto, a leitura estava sendo abordada pelos alunos de um ponto de vista crítico, uma vez que esperavam por meio dela descobrir como a língua estaria funcionando para atingir os propósitos determinados pelo contexto. Com o objetivo de oferecer suporte teórico para suas reflexões, a instrutora solicitou como tarefa de casa a leitura de Selzer (2004), um texto que explica como a língua funciona para atingir objetivos determinados pelo contexto.

\section{Aula 5}

$\mathrm{Na}$ quinta aula, os alunos foram introduzidos aos elementos do contexto, segundo a escola australiana de gêneros textuais: os conceitos de campo, relação, modo e cultura. Esses elementos foram introduzidos como uma alternativa para os propostos por Selzer (2004) para a compreensão da relação lingua-contexto. A instrutora analisou com os alunos alguns abstracts para explicar como esses elementos se relacionam entre si para atingir o objetivo do gênero. Com o objetivo de explorar como estes elementos estão presentes no texto argumentativo, a instrutora solicitou a leitura dos seguintes textos: Martin (1989), Hyland (1990) e Fulkerson (1996). Estes textos abordam diretamente os aspectos lingüísticos e sociais presentes no texto argumentativo, oferecendo-lhes aporte teórico para entender de que forma o ACP se manifesta concretamente neste gênero, capacitando-lhes para a escrita efetiva desse tipo de texto.

\section{Aula 6}

A sexta aula foi dedicada à discussão do texto do Martin, que explora e explica o propósito do texto argumentativo e o conceito de tese. Os alunos tiveram a oportunidade de analisarem um texto argumentativo a partir das informações contidas no texto mencionado. 


\section{Aula 7}

Na sétima aula, a instrutora utilizou convites de casamento para explorar melhor os conceitos de campo, relação, modo e cultura e as relações entre eles, e entre eles e a língua, para formar os gêneros.

Por meio do gênero convite de casamento foi, inclusive, possível demonstrar como o contexto é influenciado pela língua à medida que, mesmo com todas as mudanças sociais ocorridas nos últimos anos, o convite, tradicionalmente formal, influencia a manutenção da formalidade na celebração desse tipo de evento. Foi possível também, comparar este gênero do ponto de vista da cultura (por meio da comparação entre convites escritos em inglês e em português) e como os demais elementos do contexto estão modificando este gênero que já é, inclusive, enviado por email e escritos de maneira mais informal (tenor), por exemplo, quando são os próprios noivos, e não mais seus pais, que convidam e cuja linguagem misturada com imagens de caricaturas dos noivos dão um tom irreverente e informal ao que tradicionalmente corresponde a um evento formal.

Com os conceitos expostos na lousa, por motivo da explicação, os alunos foram convidados a desenharem seu primeiro "germ-cell" (A2). A instrutora pediu para que eles relacionassem os conceitos discutidos utilizando figuras como setas, círculos etc.

\section{Aula 8}

Na oitava aula, os alunos realizaram uma atividade com um texto argumentativo em que tinham que identificar a tese e os movimentos característicos deste gênero, conforme Hyland (1990). Nesta aula, a instrutora pediu que os alunos desenhassem sua compreensão de gênero (A3) e, posteriormente, do texto argumentativo (A3). 
Aula 9

Os alunos responderam a pesquisa de avaliação do curso e realizaram o pósteste. Com os modelos do texto argumentativo em mãos, a instrutora explicou que poderiam utilizá-lo durante a produção do seu texto (A4), no entanto, não foram questionados se houve ou não utilização.

\section{Avaliação}

Os alunos foram avaliados por sua participação no conjunto das atividades realizadas: nas discussões (que pressupunham leitura e reflexão), nas atividades em grupo, na realização dos testes e nas respostas aos diários. 


\section{Metodologia}

Esta pesquisa focaliza as concepções de língua e escrita de seis alunos de um curso de escrita em inglês fundamentado na perspectiva conceitual (FERREIRA, 2005) ${ }^{6}$. Partindo de uma visão vygotskiana de desenvolvimento e aprendizagem (VYGOTSKY, 1978, 1987) e tendo como referência as concepções de língua e escrita subjacentes às três principais abordagens para o ensino da escrita em inglês (cf. FERREIRA, 2005, 2011), nosso objetivo é investigar se ocorre ou não mudança nas concepções de língua e escrita dos alunos ao longo do curso. Nesse sentido, elaboramos a seguinte pergunta de pesquisa: houve mudança nas concepções de língua e escrita dos alunos ao longo do curso?

Para responder a essa pergunta de pesquisa, procuramos identificar as concepções de língua e escrita dos alunos, no início ( $1^{\text {a }}$ etapa da análise) e ao longo do curso ( $2^{\mathrm{a}}$ etapa da análise), através de palavras e/ou expressões que indicassem o modo como eles compreendiam esses conceitos. Os dados foram coletados de fontes diversas (conforme a tabela 1 , abaixo), por meio de questionários e diários ${ }^{7}$ categorizados $^{8} \mathrm{e}$ analisados por meio da triangulação das informações obtidas.

\section{Tabela 1 - Fontes de dados e abreviações}

\begin{tabular}{|l|l|}
\hline Fontes de dados & Abreviações utilizadas \\
\hline Exame de Proficiência (anexo A) & EP \\
\hline
\end{tabular}

\footnotetext{
${ }^{6}$ Conforme exposto na fundamentação teórica deste trabalho, a perspectiva conceitual constitui uma abordagem para o ensino da escrita em inglês que visa à promoção do desenvolvimento cognitivo dos alunos na forma de pensamento teórico (FERREIRA, 2005; FERREIRA; LANTOLF, 2008).

${ }^{7}$ Os questionários e diários são instrumentos tradicionalmente utilizados na abordagem contextual das pesquisas sobre crenças (cf. BARCELOS, 2004 citada por ROCHA, 2010). Barcelos (2001) distingue três abordagens para os estudos sobre crenças: normativa, metacognitiva e contextual. Na abordagem contextual "as crenças são inferidas dentro do contexto de atuação do participante investigado" (VIEIRAABRAHÃO, 2006).

${ }^{8}$ A categorização dos dados foi realizada com base nos próprios dados coletados como normalmente ocorre nesse tipo de pesquisa (cf. SILVA, 2007).
} 


\begin{tabular}{|l|l|}
\hline Ficha de Identificação (anexo B) & FI \\
\hline Diários Dialogados & DD \\
\hline
\end{tabular}

Conforme a tabela 2 (abaixo), os dados coletados no início do curso ( $1^{\mathrm{a}}$ etapa da análise) correspondem 1) às respostas das alunas à questão dissertativa (questão A) presente no Exame de Proficiência (anexo C) e 2) às suas respostas às questões presentes na Ficha de Identificação (anexo D). Os dados coletados ao longo do curso (2a etapa da análise) correspondem 1) aos seus depoimentos e 2) às respostas às questões propostas pela instrutora nos diários dialogados. Foram consideradas como unidades de análise as palavras e/ou expressões relacionadas aos seguintes aspectos: 1) seus objetivos em relação ao curso e/ou, especificamente, à escrita; 2) a frequência e a natureza das atividades em que utilizam (ou utilizaram) a escrita, 3) suas principais dificuldades em relação à escrita e 4) suas definições de conceitos relacionados à língua e/ou à escrita ${ }^{9}$.

Tabela 2 - Fontes, dados e unidades de análise

\begin{tabular}{|c|c|c|}
\hline Fontes de dados & Dados & $\begin{array}{l}\text { Unidades de } \\
\text { análise }\end{array}$ \\
\hline $\begin{array}{l}\mathbf{1}^{\mathrm{a}} \text { etapa da } \\
\text { análise }\end{array}$ & & \\
\hline $\begin{array}{l}\text { 1. Exame de } \\
\text { proficiência } \\
\text { (questão A) } \\
\text { (anexo A) } \\
\begin{array}{l}\text { 2. Ficha de } \\
\text { identificação } \\
\text { (anexo B) }\end{array}\end{array}$ & $\begin{array}{l}\text { 1. Respostas dos alunos à } \\
\text { questão dissertativa presente } \\
\text { no exame de proficiência } \\
\text { (anexo C) } \\
\text { 2. Respostas dos alunos às } \\
\text { perguntas elaboradas na } \\
\text { Ficha de identificação }\end{array}$ & $\begin{array}{lr}\text { Expressões } & \text { que } \\
\text { indicam: } & \\
\text { 1) } & \text { seus } \\
\text { objetivos em } \\
\text { relação } & \text { ao } \\
\text { curso e/ou à } \\
\text { escrita em } \\
\text { inglês; }\end{array}$ \\
\hline
\end{tabular}

\footnotetext{
${ }^{9}$ Esses aspectos foram destacados para possibilitar a triangulação de informações, fundamental no estudo sobre crenças segundo Barcelos e Vieira-Abrahão (2006). As autoras explicam que crenças são unidades complexas que não podem ser investigadas por meio de perguntas diretas.
} 


\begin{tabular}{|c|c|c|}
\hline & (anexo D) & $\begin{array}{l}\text { 2) a frequência } \\
\text { e a natureza dos } \\
\text { usos da escrita } \\
\text { em inglês; } \\
\text { 3) dificuldades } \\
\text { em relação à } \\
\text { escrita em } \\
\text { inglês. }\end{array}$ \\
\hline \multicolumn{3}{|l|}{$\begin{array}{l}2^{\mathrm{a}} \text { etapa da } \\
\text { análise }\end{array}$} \\
\hline $\begin{array}{l}\text { 3. Diários } \\
\text { dialogados }\end{array}$ & $\begin{array}{l}\text { 1. Depoimentos/reflexões dos } \\
\text { alunos em relação às } \\
\text { atividades e assuntos } \\
\text { tratados em aula }\end{array}$ & 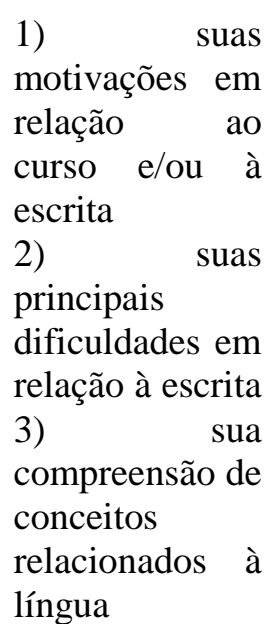 \\
\hline
\end{tabular}

\subsection{Contexto e participantes}

O curso ${ }^{10}$ de onde os dados foram coletados foi planejado e ministrado pela própria pesquisadora. Intitulado "Praticando a escrita em inglês por meio de gêneros textuais: a argumentação", foi oferecido como curso de extensão em uma universidade pública do estado de São Paulo. As aulas foram realizadas aos sábados, das 10h às $13 \mathrm{~h}$, de 18/09/2010 à 11/12/2010, totalizando vinte e sete horas. Seis alunas ${ }^{11}$ consentiram em participar da pesquisa sem nenhum tipo de remuneração: MA, DI, NA, RE, LU e $\mathbf{S A}^{12}$. Suas idades variam entre 23 e 51 anos. A maioria (MA, NA, RE e LU) possui

\footnotetext{
${ }^{10} \mathrm{O}$ conteúdo e a metodologia de ensino utilizados no curso encontram-se descritos no segundo capítulo dessa dissertação, item 2.4.2.

${ }^{11}$ Dos oito alunos frequentes, dois não chegaram a produzir dados suficientes que pudessem ser incluídos na pesquisa.

${ }_{12}$ As alunas participantes da pesquisa são identificadas por códigos para que suas identidades sejam preservadas.
} 
graduação em Letras ${ }^{13}$ e apenas uma (Re) não é pós-graduada, conforme mostra a tabela 3 (abaixo):

Tabela 3 - Perfil dos participantes (fontes: CV e FI) ${ }^{14}$

\begin{tabular}{|c|c|c|c|c|}
\hline Participantes & Idade & Graduação & $\begin{array}{l}\text { Formação } \\
\text { atual }\end{array}$ & Profissão \\
\hline MA & 51 & $\begin{array}{l}\text { Letras } \\
\text { (Português- } \\
\text { Inglês) }\end{array}$ & $\begin{array}{ll}\text { Mestre } & \text { em } \\
\text { Educação } & \\
\text { (Formação } & \text { de } \\
\text { professores) } & \end{array}$ & $\begin{array}{l}\text { Professora } \\
\text { universitária (área de } \\
\text { inglês) }\end{array}$ \\
\hline DI & 43 & Educação Física & $\begin{array}{l}\text { Doutora em } \\
\text { Nutrição } \\
\text { Humana } \\
\text { Aplicada }\end{array}$ & $\begin{array}{l}\text { Fisiologista do } \\
\text { exercício; nutróloga; } \\
\text { professora } \\
\text { universitária (área de } \\
\text { escrita acadêmica); } \\
\text { editora de revista }\end{array}$ \\
\hline NA & 28 & $\begin{array}{l}\text { Letras } \\
\text { (Português- } \\
\text { Inglês) }\end{array}$ & $\begin{array}{lr}\text { Mestre } & \text { em } \\
\text { Estudos } & \text { da } \\
\text { Tradução } & \end{array}$ & Tradutora \\
\hline $\mathbf{R E}$ & 23 & $\begin{array}{l}\text { Letras } \\
\text { (Português- } \\
\text { Inglês) }\end{array}$ & $\begin{array}{l}\text { Bacharel em } \\
\text { Letras }\end{array}$ & Assistente editorial \\
\hline $\mathbf{L U}$ & 36 & Letras (Inglês) & $\begin{array}{l}\text { Especialista na } \\
\text { área de Letras }\end{array}$ & Professora de inglês \\
\hline SA & 37 & $\begin{array}{l}\text { Engenharia } \\
\text { Química }\end{array}$ & $\begin{array}{l}\text { Doutoranda em } \\
\text { Engenharia } \\
\text { Química }\end{array}$ & Engenheira química \\
\hline
\end{tabular}

Todas têm uma longa história de relação com a língua inglesa, sobretudo, como aprendizes, mas também, em suas vidas profissionais, conforme mostram as tabelas 3 (acima) e 4 (abaixo). Três (MA, NA e LU) são professoras de inglês, uma (RE) trabalha em editora (realizando trabalhos de tradução e usando a língua para se comunicar) ${ }^{15} \mathrm{e}$ as

\footnotetext{
${ }^{13}$ DI e SA possuem formação em Educação Física e Engenharia Química, respectivamente.

${ }^{14}$ CV e FI são as abreviações usadas para Curriculum Vitae e Ficha de Identificação, respectivamente.

${ }^{15}$ Informação extraída de sua Ficha de Identificação (anexo D).
} 
outras duas (DI e SA) têm contato constante com a língua, principalmente, por meio da leitura de textos científicos de suas respectivas áreas.

Tabela 4 - Conhecimento e contato com a língua inglesa (fontes: FI e CV)

\begin{tabular}{|c|c|c|}
\hline Participantes & Estudo formal/Certificados & $\begin{array}{l}\text { Outras formas de contato } \\
\text { com a língua }\end{array}$ \\
\hline MA & $\begin{array}{l}\text { Escola de idiomas (Brasil e } \\
\text { exterior); graduação na área; } \\
\text { Toefl, CPE, entre outros }\end{array}$ & $\begin{array}{l}\text { Professora em escola de } \\
\text { idiomas ( } 25 \text { anos); professora } \\
\text { universitária de literatura em } \\
\text { LI ( } 3 \text { anos); TV (filmes e } \\
\text { outros programas); leitura }\end{array}$ \\
\hline DI & $\begin{array}{l}\text { Estudou com professor } \\
\text { particular até o Mestrado; fez } \\
\text { todos os níveis do English on } \\
\text { Campus e o Instrumental I e } \\
\text { II na FFLCH-USP }\end{array}$ & Filmes; música \\
\hline NA & $\begin{array}{l}\text { Escola de idiomas; graduação } \\
\text { na área }\end{array}$ & $\begin{array}{ll}\text { Professora } & \text { particular; } \\
\text { tradutora; leitura } & \text { de textos } \\
\text { acadêmicos } & \end{array}$ \\
\hline $\mathbf{R E}$ & $\begin{array}{lr}\text { Graduação na } & \text { área; } \\
\text { atualmente estuda em } & \text { escola } \\
\text { de idiomas } & \text { (nível } \\
\text { intermediário) } & \end{array}$ & $\begin{array}{l}\text { Trabalha em editora e realiza } \\
\text { trabalhos de tradução e se } \\
\text { comunica por email com } \\
\text { editoras de outros países }\end{array}$ \\
\hline $\mathbf{L U}$ & $\begin{array}{l}\text { Escola de idiomas (Brasil e } \\
\text { exterior); graduação na área }\end{array}$ & $\begin{array}{llll}\text { Professora em escola } & \text { de } \\
\text { idiomas } & & & \end{array}$ \\
\hline SA & $\begin{array}{l}\text { Escola de idiomas; grande } \\
\text { parte do material utilizado na } \\
\text { graduação era em inglês; } \\
\text { curso de escrita acadêmica } \\
\text { em inglês; certificado } \\
\text { intermediário da Cambridge }\end{array}$ & $\begin{array}{l}\text { Leitura de textos científicos } \\
\text { (todo o material técnico } \\
\text { utilizado em sua profissão é } \\
\text { em inglês) e de ficção; TV }\end{array}$ \\
\hline
\end{tabular}

\section{Análise e discussão dos dados}


A identificação das concepções de língua e escrita dos alunos, como mencionado no capítulo anterior, será realizada com base nas informações sobre as diferentes concepções de língua e escrita subjacentes às principais abordagens para o ensino da escrita em língua estrangeira, tratadas na fundamentação teórica desse trabalho.

Conforme vimos, as três principais abordagens para o ensino da escrita tradicional, processual e social - apresentam diferentes visões de língua e ensino dessa habilidade (cf. FERREIRA, 2005, 2011). A abordagem tradicional concebe a língua como um sistema de códigos, desvinculada do indivíduo e do contexto social em que é utilizada. Influenciada pelo behaviorismo, essa abordagem considera a escrita como um hábito a ser adquirido por meio da imitação de textos considerados bons. Seu ensino limita-se, dessa forma, à correção gramatical com o objetivo de que o erro, considerado um mau hábito, seja evitado (FERREIRA, 2011).

A abordagem processual, como observou Ferreira (2011), concebe a língua como um instrumento para a expressão da criatividade dos alunos. A escrita é, nesse sentido, concebida como um instrumento para o desenvolvimento e expressão de idéias. O ensino da escrita focaliza a livre expressão de ideias por meio da produção de diários, de múltiplas versões de um mesmo texto, conferências e instrução implícita. Em outras palavras, confere-se maior atenção ao processo, todavia o texto como produto continua sendo o foco e, dessa forma, a língua continua desvinculada do contexto social do qual se origina e, em relação à cognição humana, não passa de um meio de expressão, e não construção de sentido.

A abordagem social, por sua vez, focaliza o aspecto social da língua, concebendo-a, em um sentido geral, como prática social (conceito que se estende também à escrita). Por meio, sobretudo, das escolas de gêneros textuais, a relação língua-contexto é explorada e o conceito de gênero torna-se um importante instrumento 
utilizado para o ensino da escrita. Enfatiza-se, dessa forma, a função social da língua, mas, conforme explica Ferreira (2011), desconsidera-se sua função cognitiva/reguladora que também cumpre papel relevante nas atividades práticas do homem no mundo promovendo seu desenvolvimento cognitivo (VYGOTSKY, 1978, 1987; LEONTIEV, $1981)^{16}$.

A tabela abaixo (tabela 5) apresenta de forma esquemática as concepções de língua e escrita relacionadas às respectivas abordagens para o ensino da escrita em língua estrangeira, tal como as descrevemos nesse texto:

Tabela 5 - Abordagens e respectivas concepções de língua e escrita

\begin{tabular}{|c|c|c|}
\hline Abordagens & Concepções de língua & Concepções de escrita \\
\hline Tradicional & um sistema de códigos & $\begin{array}{l}\text { um hábito a ser adquirido a } \\
\text { partir da imitação de textos } \\
\text { considerados bons com foco } \\
\text { na correção gramatical; }\end{array}$ \\
\hline Processual & $\begin{array}{llr}\text { um sistema } & \text { de } & \text { códigos } \\
\text { utilizado } & \text { para } & \text { o } \\
\text { desenvolvimento e expressão } \\
\text { de ideias }\end{array}$ & $\begin{array}{l}\text { instrumento para } 0 \\
\text { desenvolvimento e expressão } \\
\text { da criatividade dos alunos }\end{array}$ \\
\hline Social & atividade/prática social & Idem à concepção de língua \\
\hline
\end{tabular}

A tabela a seguir (tabela 6) apresenta as abordagens e as práticas de ensino a elas relacionadas. Esquematizar essa informação é importante uma vez que as concepções de língua e escrita dos alunos normalmente apresentam-se vinculadas a concepções de como seu ensino é conduzido.

Tabela 6 - Abordagens e práticas de ensino relacionadas

\begin{tabular}{|l|l|}
\hline Abordagens & Práticas de ensino \\
\hline
\end{tabular}

${ }^{16}$ Desse ponto de vista, a escrita é considerada, não apenas prática social, mas também instrumento simbólico responsável pelo desenvolvimento da consciência do indivíduo ou, em outras palavras, como elemento regulador (mediador) de suas atividades práticas no mundo. 


\begin{tabular}{|l|l|}
\hline Tradicional & imitação de textos; correção gramatical \\
\hline Processual & $\begin{array}{l}\text { foco na livre expressão de ideias por meio da } \\
\text { produção de diários, de múltiplas versões de } \\
\text { um mesmo texto, conferências e instrução } \\
\text { gramatical implícita }\end{array}$ \\
\hline Social & $\begin{array}{l}\text { a relação língua-contexto é explorada e o } \\
\text { conceito de gênero torna-se um importante } \\
\text { instrumento utilizado para o ensino }\end{array}$ \\
\hline
\end{tabular}

\section{1. $1^{\mathrm{a}}$ etapa da análise}

Conforme mencionado no capítulo anterior, a primeira etapa da análise visa identificar as concepções de língua e escrita apresentadas pelas alunas no início do curso. Conforme exposto na tabela 2, as fontes de dados para esta fase constituem o Exame de Proficiência (anexo A) e a Ficha de Identificação (anexo B). Os dados correspondem às respostas das alunas à questão A do Exame de Proficiência (anexo C) e às suas respostas às perguntas da Ficha de Identificação (anexo D). Conforme explicamos anteriormente, procuramos, nesses dados, palavras e/ou expressões produzidas pelas alunas que indicassem 1) seus objetivos em relação ao curso e/ou à escrita, 2) a frequência e a natureza das atividades em que utilizam e/ou utilizaram a escrita e 3) suas principais dificuldades em relação à escrita. Essas expressões foram organizadas em duas tabelas ${ }^{17}$ : a primeira (tabela 7) apresenta as expressões que indicam seus objetivos ${ }^{18}$; a segunda (tabela 8) apresenta as expressões que indicam uso, frequência de usos e dificuldades ${ }^{19}$.

\footnotetext{
${ }^{17}$ As expressões encontram-se destacadas em negrito.

${ }^{18}$ Os dados sobre os objetivos foram gerados a partir das seguintes questões: 1) Why do you think this course is important for you? How do you relate it to your personal or professional experience? Which goals do you expect to achieve through it? (Try to answer these questions writing a short text about the topic outlined by them) (questão A do Exame de Proficiência) e 2) Por que você se inscreveu neste curso? O que você espera que ele te proporcione? (Ficha de Identificação)

19 Os dados sobre os usos e frequência de usos e dificuldades foram gerados a partir das seguintes questões da Ficha de Identificação: Em que ocasiões e com que frequência você usa o inglês? Como você avalia o seu desempenho? Está satisfeito? Quais são suas principais dificuldades? Em que ocasiões você
} 
Tabela 7 - Expressões que indicam os objetivos das participantes em relação ao curso e/ou à escrita (fontes: EP e FI)

\begin{tabular}{|c|c|c|}
\hline Participantes & EP & FI \\
\hline MA & $\begin{array}{l}\text { "understand this teaching } \\
\text { approach" }\end{array}$ & $\begin{array}{l}\text { "ajudar um aluno que tem } \\
\text { dificuldades em produzir um } \\
\text { texto"; "busco aporte teórico } \\
\text { para minhas reflexões e } \\
\text { práticas" }\end{array}$ \\
\hline DI & $\begin{array}{l}\text { "feel well to write"; "it's } \\
\text { necessary for my academic } \\
\text { and professional carreer" }\end{array}$ & $\begin{array}{l}\text { "Liberdade na escrita. } \\
\text { Quero me sentir segura para } \\
\text { escrever como me sinto para } \\
\text { falar." }\end{array}$ \\
\hline NA & $\begin{array}{l}\text { "improve writing skills"; } \\
\text { "need a lot of training"; } \\
\text { "achieve more confidence } \\
\text { and vocabulary" }\end{array}$ & $\begin{array}{l}\text { "desejo entrar no mercado } \\
\text { de tradução (agências, } \\
\text { editoras etc.) e para isso } \\
\text { preciso estar treinada para } \\
\text { participar de testes escritos" }\end{array}$ \\
\hline RE & $\begin{array}{l}\text { "I wish I was more prepared } \\
\text { to use the language in } \\
\text { writing" }\end{array}$ & $\begin{array}{l}\text { "[...] não sinto uma } \\
\text { segurança total na hora de } \\
\text { redigir para um native- } \\
\text { speaker [...]"; "escrever de } \\
\text { forma apropriada e eficaz } \\
\text { sem sofrer na hora de usar } \\
\text { uma 'preposition', ou uma } \\
\text { 'collocation' ou uma } \\
\text { 'phrasal verb"; } \\
\text { "Quero estar apta a compor } \\
\text { essays, redigir e-mails em } \\
\text { inglês sem ficar horas depois } \\
\text { revisando, no receio de ter } \\
\text { inserido erros na escrita, } \\
\text { perder a sensação de estar } \\
\text { em uma "prova de fogo" na } \\
\text { hora de fazer um abstract e } \\
\text { internalizar as regras da } \\
\text { escrita, de modo a se tornar } \\
\text { mais natural a prática da } \\
\text { escrita em inglês" }\end{array}$ \\
\hline $\mathbf{L U}$ & $\begin{array}{l}\text { "studying for the CAE"; } \\
\text { "practice my writing, improve } \\
\text { it" }\end{array}$ & $\begin{array}{l}\text { "[...] necessidade dos } \\
\text { certificados internacionais } \\
{[\ldots] \text { fazer o } C A E[\ldots] \text { na }} \\
\text { escola onde trabalho é } \\
\text { extremamente importante } \\
{[\ldots] "}\end{array}$ \\
\hline
\end{tabular}

já escreveu (ou escreve) em inglês e com que frequiência? Você está escrevendo algum texto em inglês atualmente? E no futuro próximo (2-3 meses)? Você tem dificuldades em escrever em inglês? Se sim, quais são elas? 


\begin{tabular}{|l|l|l|}
\hline SA & $\begin{array}{l}\text { "improve my writing "Considero que tenho certo } \\
\text { abilities"; "publish articles"; } \\
\text { "have a good writing in } \\
\text { English" }\end{array}$ & $\begin{array}{l}\text { bloqueio para a escrita e } \\
\text { fiquei entusiasmada em } \\
\text { participar de uma nova } \\
\text { metodologia de ensino que } \\
\text { incentiva a ascrita } \\
\text { freqüente."; a ascrever } \\
\text { artigos científicos" }\end{array}$ \\
\hline
\end{tabular}

Tabela 8 - Usos, frequência de usos e dificuldades das participantes em relação à escrita (fontes: EP; FI)

\begin{tabular}{|c|c|c|}
\hline Nomes & Uso/freqüîncia & Dificuldades \\
\hline MA & $\begin{array}{l}\text { "Escrevi muito enquanto } \\
\text { estudava } \\
\text { 'formalmente', mas agors } \\
\text { praticamente não o faço } \\
\text { mais" }\end{array}$ & $\begin{array}{l}\text { "Falta de vocabulário e um pouco de } \\
\text { incerteza em relação às estruturas - } \\
\text { principalmente uso de preposições e } \\
\text { das 'collocations"" }\end{array}$ \\
\hline DI & $\begin{array}{l}\text { "Não tenho usado mais pq } \\
\text { saí da área de pesquisa de alto } \\
\text { nível"; "Nos abstracts dos } \\
\text { textos que já produzi }[\ldots] \text { "..]" }\end{array}$ & $\begin{array}{l}\text { "Penso q vocabulário e gramática... } \\
\text { desejo q vc me aponte com mais } \\
\text { precisão.." }\end{array}$ \\
\hline NA & $\begin{array}{l}\text { "Costumo escrever nas } \\
\text { anotações dos textos que leio } \\
{[\ldots] \text { numa freqüência de uma }} \\
\text { ou duas vezes por semana"; } \\
\text { "[...] caso surja algum } \\
\text { trabalho de versão para } \\
\text { fazer" }\end{array}$ & $\begin{array}{l}\text { "[...] tenho dificuldade com a } \\
\text { espontaneidade em escrever, parece } \\
\text { que existe uma distância entre a } \\
\text { criatividade, as idéias (texto pensado) } \\
\text { e o que resulta disso (texto escrito). } \\
\text { Além disso, manter o registro do } \\
\text { discurso do início ao fim fica difícil } \\
\text { por conta da falta de treino com o } \\
\text { vocabulário, bem como a regência } \\
\text { dos verbos - questão de gramática } \\
\text { mais problemática do inglês, a meu } \\
\text { ver" }\end{array}$ \\
\hline RE & $\begin{array}{l}\text { "Escrevo inglês } \\
\text { semanalmente no curso de } \\
\text { idiomas, esporadicamente no } \\
\text { trabalho em contatos com } \\
\text { editoras estrangeiras e } \\
\text { raramente com algum colega. } \\
\text { Já realizei alguns trabalhos } \\
\text { curtos de versão também. De } \\
\text { fato, minha prática maior é } \\
\text { com a leitura..." }\end{array}$ & $\begin{array}{l}\text { "Sinto dificuldade mais na hora de } \\
\text { adotar uma construção mais } \\
\text { adequada, ou às vezes com um } \\
\text { vocabulary ou ponctuation }[\ldots] "\end{array}$ \\
\hline $\mathbf{L U}$ & "Na época da graduação e & "Acho que as maiores dificuldades \\
\hline
\end{tabular}




\begin{tabular}{|c|c|c|}
\hline & $\begin{array}{l}\text { pós-graduação escrevia com } \\
\text { maior frequência, atualmente, } \\
\text { faço alguns relatórios para a } \\
\text { escola onde trabalho que } \\
\text { devem ser em inglês, mas são } \\
\text { textos breves e simples, nada } \\
\text { que me faça estudar novos } \\
\text { vocábulos". } \\
\text { "Pretendo praticar nos } \\
\text { próximos meses para enfim } \\
\text { por volta do primeiro } \\
\text { semestre de } 2011 \text { fazer o } \\
\text { exame que mencionei } \\
\text { anteriormente }(C A E) \text { ". }\end{array}$ & $\begin{array}{l}\text { são quanto ao vocabulário } \\
\text { (sinônimos), collocation, e qual a } \\
\text { melhor opção quando existem } \\
\text { palavras que podem ser sinônimas, } \\
\text { mas apresentam uma sutil diferença, } \\
\text { que podem modificar o que se } \\
\text { pretende dizer". }\end{array}$ \\
\hline $\mathbf{S A}$ & $\begin{array}{l}\text { "A minha freqüiência atual é } \\
\text { nula e já me prejudiquei, pois } \\
\text { deixei de publicar um } \\
\text { trabalho de } 20 \text { páginas em um } \\
\text { congresso no mês de maio } \\
\text { deste ano". }\end{array}$ & $\begin{array}{l}\text { "[...] tenho muitas dificuldades. É } \\
\text { muito doloroso começar e sempre } \\
\text { tenho desculpas para não } \\
\text { continuar" }\end{array}$ \\
\hline
\end{tabular}

\subsubsection{Análise dos dados referentes aos objetivos (tabela 7)}

\subsubsection{Categorização dos objetivos}

Os dados apresentados na tabela 7, referentes aos objetivos dos alunos, apresentam expressões relativas 1) ao curso, 2) à aprendizagem da escrita e 3) à utilização da escrita. De um modo geral, é possível distinguir três categorias de objetivos: 1) 'emocional', 2) 'profissional e/ou acadêmico' e 3) 'escolar'. A categoria 'emocional' foi criada para representar o interesse de algumas alunas em aprender a escrita por motivos claramente ligados a aspectos emocionais ("perder a sensação de estar em uma "prova de fogo" na hora de fazer um abstract" (RE) ou "feel well to write" (DI), por exemplo). A categoria 'profissional e/ou acadêmico' representa o interesse das alunas em aprender (ou utilizar) a escrita (ou a abordagem utilizada no curso) em benefício de sua carreira profissional e/ou acadêmica ("[...] necessidade dos certificados internacionais [...] (LU); "publish articles" (SA); "busco aporte teórico 
para minhas reflexões e práticas" (MA), por exemplo). A categoria 'escolar', por sua vez, refere-se à produção de textos para fins de aprendizado e avaliação próprios do contexto escolar, como treinamento de estruturas gramaticais e vocabulário (““[...] usar uma 'preposition', ou uma 'collocation' ou uma 'phrasal verb'”; “Quero estar apta a compor essays [...]" (RE), por exemplo).

A categorização dos objetivos encontra-se representada na tabela 9 (abaixo):

Tabela 9 - Categorização dos objetivos e exemplos

\begin{tabular}{|c|c|}
\hline Categorias de objetivos & Exemplos \\
\hline 1. Emocional & 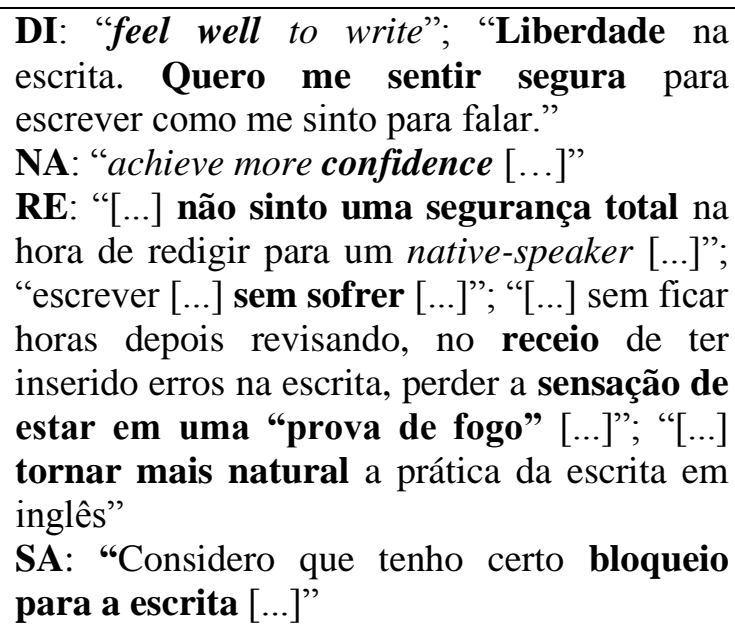 \\
\hline 2. Profissional e/ou acadêmico & $\begin{array}{l}\text { MA: "understand this teaching approach"; } \\
\text { "ajudar um aluno que tem dificuldades em } \\
\text { produzir um texto"; "busco aporte teórico } \\
\text { para minhas reflexões e práticas" } \\
\text { DI: "it's necessary for my academic and } \\
\text { professional carreer" } \\
\text { RE: "Quero estar apta a [...] redigir e-mails"; } \\
{[\ldots] \text { fazer um abstract" }} \\
\text { LU: "studying for the CAE"; "[...] } \\
\text { necessidade dos certificados internacionais } \\
{[\ldots] \text { fazer o CAE [...] na escola onde }} \\
\text { trabalho extremamente importante }[. . .] " \\
\text { SA: "publish articles"; "escrever artigos } \\
\text { científicos" }\end{array}$ \\
\hline 3. Escolar & $\begin{array}{l}\text { NA: "improve writing skills"; "need a lot of } \\
\text { training"; "achieve more [...] vocabulary"; } \\
\text { "preciso estar treinada para participar de } \\
\text { testes escritos" } \\
\text { RE: "I wish I was more prepared to use the } \\
\text { language in writing"; "escrever de forma }\end{array}$ \\
\hline
\end{tabular}




\begin{tabular}{|l|l|}
\hline & $\begin{array}{l}\text { apropriada e eficaz [...]"; “[...] usar uma } \\
\text { 'preposition', ou uma "collocation' ou uma } \\
\text { 'phrasal verb"”; "Quero estar apta a compor } \\
\text { essays [...]"; "[...] internalizar as regras da } \\
\text { escrita" } \\
\text { LU: "practice my writing, improve it" } \\
\text { SA: "improve my writing abilities"; "have a } \\
\text { good writing in English" }\end{array}$ \\
\hline
\end{tabular}

Na tabela 10 (abaixo) são apresentados os tipos de objetivos mencionados por cada participante e as respectivas expressões utilizadas. Em seguida, apresentamos, por meio de uma tabela (tabela 11) e de um gráfico (gráfico 1), a recorrência dessas categorias de objetivos entre as participantes.

Tabela 10 - Alunas, objetivos e expressões utilizadas (Fontes: EP e FI)

\begin{tabular}{|c|c|c|}
\hline Alunas & Categorias de objetivos & Expressões utilizadas \\
\hline MA & $\begin{array}{l}\text { 1. Profissional e/ou } \\
\text { acadêmico }\end{array}$ & $\begin{array}{l}\text { 1. "understand this } \\
\text { teaching approach"; } \\
\text { "busco aporte teórico } \\
\text { para minhas reflexões e } \\
\text { práticas"; "ajudar um } \\
\text { aluno que tem } \\
\text { dificuldades em produzir } \\
\text { um texto" }\end{array}$ \\
\hline DI & $\begin{array}{l}\text { 1. Emocional } \\
\text { 2. Profissional e/ou } \\
\text { acadêmico }\end{array}$ & $\begin{array}{l}\text { 1. "feel well to write"; } \\
\text { "Liberdade na escrita. } \\
\text { Quero me sentir segura } \\
\text { para escrever como me } \\
\text { sinto para falar." } \\
\begin{array}{l}\text { 2. "it's necessary for my } \\
\text { academic and } \\
\text { professional carreer" }\end{array}\end{array}$ \\
\hline NA & $\begin{array}{l}\text { 1. Emocional } \\
\text { 2. Profissional } \\
\text { acadêmico } \\
\text { 3. Escolar }\end{array}$ & $\begin{array}{l}\text { 1. "achieve more } \\
\text { confidence" } \\
\text { 2. "desejo entrar no } \\
\text { mercado de tradução } \\
\text { (agências, editoras etc.) e } \\
\text { para isso preciso estar } \\
\text { treinada para participar de } \\
\text { testes escritos" }\end{array}$ \\
\hline
\end{tabular}




\begin{tabular}{|c|c|c|}
\hline & & $\begin{array}{l}\text { 3. "[...] improve writing } \\
\text { skills"; "need a lot of } \\
\text { training"; "achieve more } \\
{[. . .] \text { vocabulary"; }}\end{array}$ \\
\hline $\mathbf{R E}$ & $\begin{array}{l}\text { 1. Emocional } \\
\text { 2. Profissional e/ou } \\
\text { acadêmico } \\
\text { 3. Escolar }\end{array}$ & $\begin{array}{l}\text { 1. "[...] não sinto uma } \\
\text { segurança total na hora } \\
\text { de redigir para um } \\
\text { native-speaker [...]"; "I } \\
\text { wish I was more prepared } \\
\text { to use the language in } \\
\text { writing"; "escrever [...] } \\
\text { sem sofrer [...]"; "[...] } \\
\text { sem ficar horas depois } \\
\text { revisando, no receio de } \\
\text { ter inserido erros na } \\
\text { escrita, perder a sensação } \\
\text { de estar em uma "prova } \\
\text { de fogo" [...]"; "[..] } \\
\text { internalizar as regras da } \\
\text { escrita, de modo a se } \\
\text { tornar mais natural a } \\
\text { prática da escrita em } \\
\text { inglês" } \\
\text { 2. "[...] fazer um abstract } \\
{[\ldots . .] " ; \text { "Quero estar apta a }} \\
{[. . .] \text { redigir e-mails em }} \\
\text { inglês" } \\
\text { 3. "escrever de forma } \\
\text { apropriada e eficaz }[. . .] \\
\text { na hora de usar uma } \\
\text { 'preposition', ou uma } \\
\text { 'collocation' ou uma } \\
\text { 'phrasal verb"”; "Quero } \\
\text { estar apta a compor } \\
\text { essays"; } \\
\text { internalizar as regras da } \\
\text { escrita" }\end{array}$ \\
\hline $\mathbf{L U}$ & $\begin{array}{l}\text { 2. Profissional e/ou } \\
\text { acadêmico } \\
\text { 3. Escolar }\end{array}$ & $\begin{array}{l}\text { 2. "studying for the } \\
\text { CAE"; "[...] necessidade } \\
\text { dos certificados } \\
\text { internacionais [...] fazer } \\
\text { o CAE }[\ldots] \text { na escola } \\
\text { onde trabalho é } \\
\text { extremamente } \\
\text { importante }[\ldots] " \\
\text { 3. "practice my writing, } \\
\text { improve it" }\end{array}$ \\
\hline SA & 1. Emocional & $\begin{array}{l}\text { 1. "Considero que tenho } \\
\text { certo bloqueio para a }\end{array}$ \\
\hline
\end{tabular}




\begin{tabular}{|l|l|l|}
\hline & $\begin{array}{l}\text { 2. Profissional e/ou } \\
\text { acadêmico }\end{array}$ & $\begin{array}{l}\text { escrita [...]" } \\
\text { 3. Escolar "publish articles"; } \\
\text { "escrever artigos } \\
\text { científicos" }\end{array}$ \\
& $\begin{array}{l}\text { 3. "improve my writing } \\
\text { abilities"; "have a good } \\
\text { writing in English" }\end{array}$ \\
\hline
\end{tabular}

Tabela 11 - Recorrência das categorias de objetivos

\begin{tabular}{|l|l|}
\hline Categorias de objetivos & $\mathbf{N}^{\mathbf{0}}$ de alunas \\
\hline Emocional & $4(\mathbf{D I} ; \mathbf{N A} ; \mathbf{R E} ; \mathbf{S A})$ \\
\hline Profissional e/ou acadêmico & $\begin{array}{l}\text { 6 (MA; DI; NA; RE; LU; } \\
\text { SA })\end{array}$ \\
\hline Escolar & $4(\mathbf{N A} ; \mathbf{R E} ; \mathbf{L U} ; \mathbf{S A})$ \\
\hline
\end{tabular}

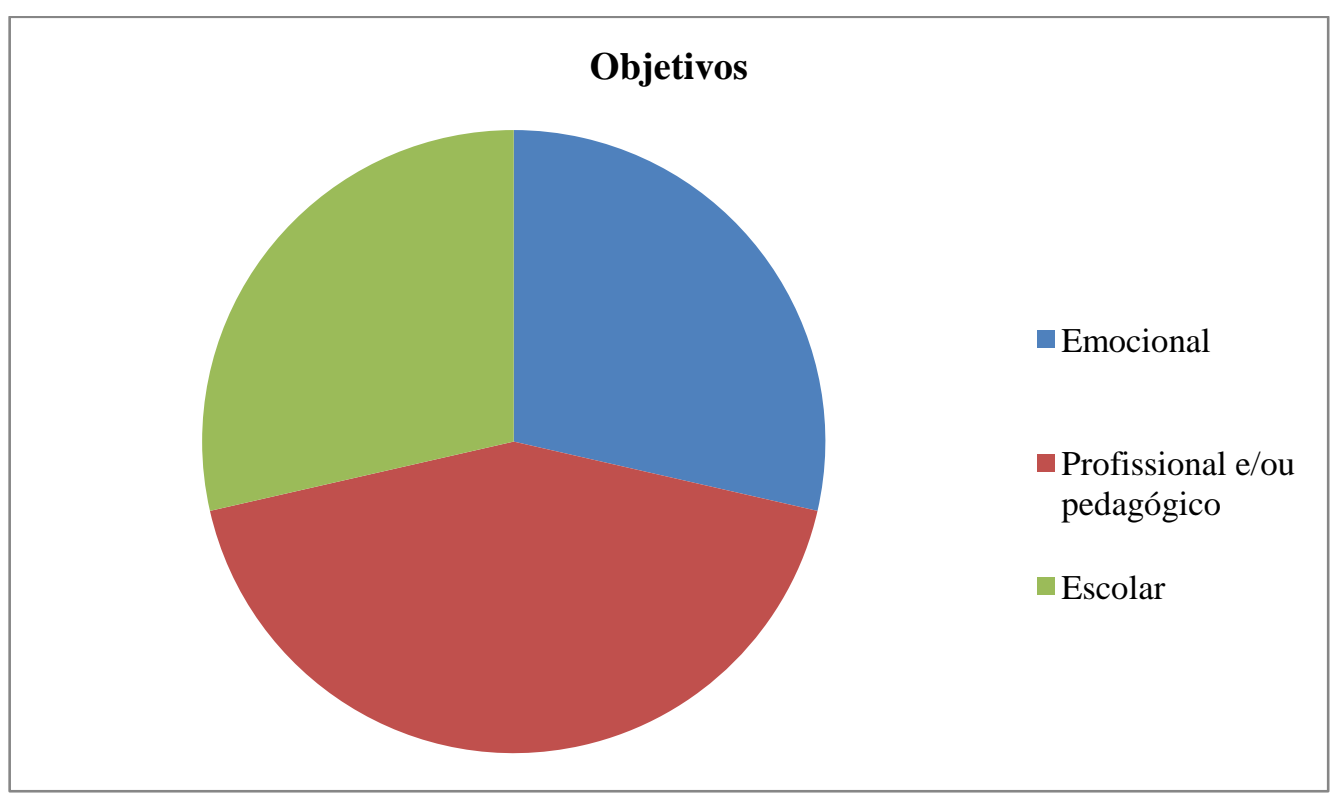

Gráfico 1 - Recorrência das categorias de objetivos 
Em relação à recorrência das categorias de objetivos, podemos realizar as seguintes observações:

1) O objetivo 'profissional e/ou acadêmico' foi o que mais se destacou entre as participantes, tendo sido apresentado por todas elas;

2) As categorias 'emocional' e 'escolar' tiveram a mesma proporção: foram apresentadas por mais da metade das alunas.

\subsubsection{Considerações preliminares referentes aos objetivos}

Visando compreender as concepções de língua e escrita das alunas no início do curso, realizaremos a primeira triangulação de informações, relacionando os dados referentes aos objetivos (analisados e categorizados acima) 1) ao perfil das participantes e 2) às informações que temos sobre seu interesse e gosto pela língua, organizadas na tabela $12(\text { abaixo })^{20}$.

Tabela 12 - Gosto e interesse pela língua inglesa (Fonte: FI)

\begin{tabular}{|l|l|}
\hline Participantes & $\begin{array}{l}\text { Expressões de gosto e interesse pela língua } \\
\text { inglesa }\end{array}$ \\
\hline MA & $\begin{array}{l}\text { "Decidi aprender inglês quando era } \\
\text { criança, porque achava 'bonito' ver colegas } \\
\text { mais velhos falando o idioma, cantando as } \\
\text { músicas, etc."; "[...] agora 'apreendo' com } \\
\text { filmes, livros, TV a cabo, etc." }\end{array}$ \\
\hline DI & $\begin{array}{l}\text { "Sou apaixonada por esta língua! Ela me foi } \\
\text { apresentada na 5'-série do ensino } \\
\text { fundamental, eu tinha 11 anos e já sábia q } \\
\text { queria muito aprendê-la. A profa foi } \\
\text { fantástica e só aumentou esta minha vontade } \\
\text { de "dominar" o idioma."; "Procuro assistir os } \\
\text { filmes sem legendas, entender as musicas e } \\
\text { tal." }\end{array}$ \\
\hline
\end{tabular}

\footnotetext{
${ }^{20}$ Esta tabela foi elaborada a partir das informações contidas nas fichas de identificação das alunas (anexo D).
} 


\begin{tabular}{|l|l|}
\hline NA & $\begin{array}{l}\text { "Comecei a estudar inglês entre 11 e 12 anos, } \\
\text { na escola regular. Desde os primeiros } \\
\text { contatos com a língua meu interesse em } \\
\text { levar adiante esse aprendizado foi } \\
\text { despertado, levando-me a ter bastante } \\
\text { atenção no que dizia respeito aos meios por } \\
\text { onde ela me era transmitida: filmes, música } \\
\text { etc." }\end{array}$ \\
\hline RE & $\begin{array}{l}\text { "Em casa, sempre ouvi muito inglês por meio } \\
\text { das músicas e filmes, e, além disso, sentia } \\
\text { uma "predisposição" para entender sem } \\
\text { muita dificuldade o que lia ou ouvia em } \\
\text { inglês." }\end{array}$ \\
\hline LU & $\begin{array}{l}\text { "Comecei a estudar inglês em escola de } \\
\text { idiomas aos 10 anos, [...] ao término foi para } \\
\text { os EUA, [...] tive oportunidade de morar em } \\
\text { casa de americanos [...] e depois foi para o } \\
\text { dormitório da universidade." }\end{array}$ \\
\hline SA & $\begin{array}{l}\text { "Comecei o aprendizado de inglês a partir da } \\
5 \text { a. série (11 anos)"; "Atualmente, sempre } \\
\text { leio um livro de ficção em inglês e assisto } \\
\text { filmes e seriados sem legendas ou com } \\
\text { legendas em inglês." }\end{array}$ \\
\hline
\end{tabular}

Conforme veremos, é possível relacionar a maioria dos objetivos mencionados pelas participantes ao seu dia-a-dia e à sua experiência de vida. No entanto, é a recorrência de categorias de objetivos incompatíveis com seus perfis (e a aparente contradição decorrente desse fato) que parece nos indicar um caminho para a identificação de suas concepções de língua e escrita.

O interesse da aluna MA em aprender sobre a escrita e em como ensiná-la, objetivo que denominamos de 'profissional e/ou acadêmico', condiz com seu perfil: ela foi professora de inglês em escola de idiomas durante vinte e cinco anos e atualmente é professora universitária na mesma área. A princípio, podemos afirmar que não há contradição aparente em seus dados. No entanto, como poderá se verificar por meio da análise do próximo conjunto de dados, seu interesse em "ajudar um aluno que tem dificuldades em produzir um texto" ou em entender a abordagem utilizada no curso, 
parece revelar um problema que ela mesma possa ter com a escrita, e não apenas um problema de falta de metodologia ou conhecimento teórico, caso contrário, ela poderia usar sua própria experiência como escritora para ajudar seus alunos.

DI é doutora na área de Nutrição Humana Aplicada, editora de uma revista e professora universitária. A categoria 'profissional e/ou acadêmica' é perfeitamente compatível com suas atividades e interesses, que incluem, por exemplo, leitura e publicação de artigos internacionais. A contradição em seus dados surge, porém, do fato de que, apesar do gosto (“Sou apaixonada por esta língua!”) e interesse pela língua ("Procuro assistir os filmes sem legendas, entender as musicas e tal.") e de tê-la estudado por vários anos (estudou com professor particular até o Mestrado, fez todos os níveis do English on Campus e o Instrumental I e II na FFLCH-USP), DI utiliza expressões que revelam sentimentos de desconforto e insegurança em relação à escrita ("feel well to write"; "Liberdade na escrita. Quero me sentir segura para escrever como me sinto para falar.”).

NA é graduada em Letras (Português-Inglês) e mestre na área de Tradução. Nessa fase de sua carreira, está se preparando para concursos (e testes em geral) e frequentando aulas no curso de pós-graduação (como aluna especial) com o objetivo de iniciar um possível doutorado ${ }^{21}$. A categoria 'profissional e/ou acadêmico' pode ser, portanto, facilmente relacionada ao seu perfil. NA precisa escrever em inglês nos testes que está realizando e, também, em artigos a serem publicados no exterior para possíveis participações em congressos, por exemplo. A contradição em seus dados é gerada pela produção de expressões que incluímos nas categorias 'emocional' ("achieve more confidence") e 'escolar' ("need a lot of training"; "achieve more (...) vocabulary"). A categoria emocional representa o interesse em perder e/ou controlar sentimentos

\footnotetext{
${ }^{21}$ Informação extraída de sua Ficha de Identificação (anexo B).
} 
negativos ao se escrever em inglês, sentimentos que, no caso de NA, poderiam nem existir ou, pelo menos, já terem sido superados frente ao seu histórico com a língua. A categoria escolar, por sua vez, representa o interesse em aprender a escrita para fins de aprendizagem (e avaliação) próprios do contexto escolar (normalmente, treinamento de vocabulário e gramática), portanto, incompatível com o perfil de uma profissional da área de línguas.

A aluna RE concluiu a graduação na área de Letras em 2009 (um ano antes do curso), estuda inglês em escola de idiomas (nível intermediário) e trabalha como assistente editorial. Ela utilizou as seguintes expressões: 1) escrever "abstracts" e "redigir emails", objetivos que incluímos na categoria 'profissional e/ou acadêmico' e que estão ligados à academia e a sua profissão, respectivamente; 2) "usar uma preposition, ou uma collocation ou uma phrasal verb", "compor essays" e "[...] internalizar as regras da escrita", objetivos que incluímos na categoria 'escolar' e que estão ligados à escola de idiomas; e 3) “[...] não sinto uma segurança total na hora de redigir para um native-speaker $[\ldots]$ ". "escrever [...] sem sofrer $[\ldots]$ ".; "[...] sem ficar horas depois revisando, no receio de ter inserido erros na escrita, perder a sensação de estar em uma "prova de fogo" [...]"; "[...] internalizar as regras da escrita, de modo a se tornar mais natural a prática da escrita em inglês", objetivos incluídos na categoria 'emocional'.

Apesar dos objetivos por ela mencionados, inclusive o 'emocional', serem compatíveis com seu perfil (concluiu a graduação há pouco tempo e ainda está estudando em escola de idiomas), as expressões usadas por ela foram as mais fortes entre as participantes, tanto aquelas referentes às necessidades de vocabulário e gramática (especificadas com detalhe, como podemos ver nos exemplos acima) como as referentes aos sentimentos em relação à língua (“escrever [...] sem sofrer [...]”; “[...] 
perder a sensação de estar em uma "prova de fogo", entre outras). A força dessas expressões negativas bem como as especificidades em relação à categoria escolar nos dados de uma profissional que, apesar de ter concluído o curso de Letras há pouco tempo, utiliza a língua em situações autênticas em seu serviço e no dia-a-dia (conforme veremos mais detalhadamente nos dados sobre usos), se não chegam a representar uma contradição em relação ao seu perfil, no mínimo, podem ser indicativas de importantes aspectos relacionados às suas concepções de língua e escrita e, portanto, devem ser levadas em consideração.

LU é professora de inglês em escola de idiomas e, nessa fase de sua vida, preocupa-se em obter certificados como forma de avançar em sua carreira. Ela utilizou expressões que incluímos nas categorias 1) 'profissional e/ou acadêmico' (“[...] necessidade dos certificados internacionais [...] fazer o $C A E[\ldots]$ na escola onde trabalho é extremamente importante [...]" e 2) 'escolar' ("practice my writing, improve it"). Podemos também dizer que, como no caso das demais participantes, a presença da categoria 'profissional e/ou acadêmico' em seus dados é compreensível, uma vez que sendo uma profissional da área de Letras precisa da escrita como instrumento para avançar em sua carreira, por exemplo, participando de testes escritos (como pretende). No entanto, como observamos em relação às demais participantes (com exceção de RE que ainda está cursando uma escola de idiomas), a categoria ‘escolar' não é compatível com seu perfil, uma vez que é graduada na área, frequentou escola de idiomas e, atualmente, é professora de inglês.

SA realiza doutorado em sua área (Engenharia Química) e, como DI (que, também, não é da área de Letras), precisa ler e escrever artigos em inglês como parte de suas atividades acadêmico-profissionais. Nesse sentido, a categoria 'profissional e/ou acadêmico' é compatível com seu perfil ("publish articles"; "escrever artigos 
científicos"). Por sua vez, a utilização de expressões incluídas nas categorias 'emocional' (“Considero que tenho certo bloqueio para a escrita [...]") e 'escolar' ("improve my writing abilities"; "have a good writing in English"), como observamos em relação a outras alunas, não parece compatível com seu perfil.

De um modo geral, podemos dizer que a principal contradição presente nos dados das participantes está ligada a incompatibilidade entre seu perfil e 1) a utilização de expressões negativas em relação à escrita (DI; NA; RE; SA) e 2) seu interesse pela aprendizagem de estruturas linguísticas básicas (NA; RE; LU; SA) ${ }^{22}$. Todas frequentaram (ou ainda frequentam, como é o caso de RE) escola de idiomas e, a maioria, com exceção de DI e SA (em cujas vidas o inglês também é fundamental ${ }^{23}$ ), possui graduação na área, sendo três já pós-graduadas. O interesse (e o gosto) pela língua começou cedo, ainda na infância ou pré-adolescência, e permaneceu constante (senão maior) ao longo de suas vidas (conforme mostram os dados sobre seus perfis nas tabelas 3 e 4). O aprendizado formal iniciou-se nessa mesma fase em escola regular e foi acompanhado de outras formas de contato com a língua: músicas, filmes, livros e programas de TV. Diante desse quadro, que revela uma relação intensa das participantes com o idioma (seu interesse e gosto pela língua bem como sua experiência por meio da aprendizagem formal e outras formas de contato), como explicar a recorrência de categorias de objetivos como a 'emocional' e a 'escolar'? A resposta para essa pergunta parece ser também parte da resposta para nossa pergunta de pesquisa, ou seja, para a compreensão das concepções de língua e escrita das alunas no início do curso.

A provável explicação é a de que as concepções de língua e escrita das alunas (no início do curso) estejam ligadas à abordagem tradicional de ensino da escrita em

\footnotetext{
${ }^{22}$ Apesar de MA não estar incluída nesses primeiros resultados, a hipótese que levantamos sobre suas possíveis dificuldades em relação à escrita é confirmada na análise do próximo conjunto de dados, revelando, dessa forma, essas mesmas contradições.

${ }^{23}$ DI é doutora em Nutrição Humana Aplicada e SA é doutoranda em Engenharia Química (cf. tabela 3).
} 
língua estrangeira que concebe a língua como um sistema de códigos, desvinculada do indivíduo e do contexto social em que é utilizada, e a escrita, por sua vez, como resultado da imitação de textos considerados bons, com foco na gramática (FERREIRA, 2005, 2007, 2011). Entendemos que a permanente preocupação das participantes com gramática e vocabulário (presente nas expressões que geraram a categoria 'escolar'), seja reflexo dessa visão de escrita como resultado e, ao mesmo tempo, demonstração (ou, simples instrumento de avaliação) de conhecimento gramatical. Os sentimentos negativos (representados, por sua vez, nas expressões que geraram a categoria 'emocional') seriam, igualmente, uma consequência dessa visão tradicional de língua em que o aluno é levado a enxergar o processo de escrita como exterior e artificial, contido nos (e limitado aos) livros e dicionários, reflexo, portanto, de algo que dificilmente poderão dominar completamente e que, por isso, geram os sentimentos de desconforto, insegurança, receio, dor e sensação de artificialidade, mencionados pelas participantes.

Conforme veremos a seguir, no segundo conjunto de dados, essas expressões negativas e expressões referentes à necessidade de conhecimentos gramatical e lexical reaparecem nos dados das alunas, corroborando, assim, a hipótese levantada acima. A triangulação das novas informações obtidas (objetivos (x perfil) x usos x dificuldades), por sua vez, nos permite compreender melhor essa hipótese e realizar novas considerações a respeito das concepções de língua e escrita das alunas.

\subsubsection{Análise dos dados referentes aos usos/frequência de usos e dificuldades (tabela 8)}

Neste ponto, focalizaremos os dados apresentados na tabela 8 , referentes aos usos (e frequência de usos) e dificuldades dos alunos em relação à escrita. 


\subsubsection{Categorização dos usos}

A tabela 13 (abaixo) apresenta a categorização dos $\operatorname{usos}^{24}$ :

Tabela 13 - Categorização dos usos

\begin{tabular}{|c|c|}
\hline Categorias de usos & Exemplos \\
\hline 1. Profissional e/ou acadêmico & $\begin{array}{l}\text { "faço alguns relatórios para a escola onde } \\
\text { trabalho" (LU) }\end{array}$ \\
\hline 2. Escolar & $\begin{array}{l}\text { "Escrevo inglês }[\ldots] \text { no curso de idiomas" } \\
(\mathbf{R E}) \text {; }\end{array}$ \\
\hline 3. Comunicativo & $\begin{array}{l}\text { "em contatos }[\ldots] \text { raramente com algum } \\
\text { colega" }(\mathbf{R E})\end{array}$ \\
\hline 4. Cognitivo & $\begin{array}{l}\text { "Costumo escrever nas anotações dos textos } \\
\text { que leio" (NA) }\end{array}$ \\
\hline
\end{tabular}

A categoria 'profisssional e/ou acadêmico' envolve a produção e circulação de textos com características específicas e direcionadas a públicos específicos, ou seja, está mais fortemente vinculada ao conceito de gêneros textuais. A categoria 'escolar' inclui os casos de simples cópias, de produção de textos para fins de avaliação ou treinamento de gramática e vocabulário. A categoria ‘comunicativo' está relacionada ao uso da língua para comunicação no dia-a-dia, por exemplo, quando deixamos recados por escrito para alguém ou enviamos mensagens por email ${ }^{25}$. A categoria ‘cognitivo' corresponde ao uso da língua como instrumento psicológico com o objetivo de se obter maior controle de ações e/ou emoções, por exemplo, quando

\footnotetext{
${ }^{24}$ Todas as categorias apresentadas na tabela 13 (bem como todas as categorias elaboradas neste estudo) estão, obviamente, interligadas, no entanto, a classificação sugerida objetiva destacar aspectos que poderão nos auxiliar na interpretação dos dados.

${ }^{25}$ Nessa categoria, a escrita apresenta-se praticamente como transcrição da fala. É importante também deixar claro que não é qualquer tipo de texto enviado por email que pertence a essa categoria, apenas aqueles que, praticamente, reproduzem a fala, ou seja, cuja função é a comunicação cotidiana comum, desvinculada de qualquer gênero textual específico.
} 
fazemos anotações de um texto para o entendermos melhor, ou quando escrevemos em um diário para expressar nossos sentimentos.

A tabela 14 (abaixo) apresenta as categorias de usos em relação às participantes e as expressões por elas utilizadas. Apesar de constarem na tabela, as expressões que não indicam uso atual da língua, não aparecem categorizadas. Essas expressões serão, todavia, consideradas na análise e discussão dos dados.

Tabela 14 - Participantes, categorias de usos e expressões utilizadas

\begin{tabular}{|c|c|c|}
\hline Participantes & $\begin{array}{ll}\text { Categorias } & \text { de } \\
\text { usos/frequência atual }\end{array}$ & Expressões utilizadas \\
\hline MA & & $\begin{array}{l}\text { "Escrevi muito } \begin{array}{r}\text { enquanto } \\
\text { inglês }\end{array} \\
\text { estudava } \\
\text { 'formalmente', mas agora } \\
\text { praticamente não o faço } \\
\text { mais" }\end{array}$ \\
\hline DI & & $\begin{array}{l}\text { "Não tenho usado mais pq saí } \\
\text { da área de pesquisa de alto } \\
\text { nível"; "Nos abstracts dos } \\
\text { textos que já produzi [...]" }\end{array}$ \\
\hline NA & $\begin{array}{l}\text { 1. Profissional e/ou } \\
\text { acadêmico } \\
\text { 4. Cognitivo }\end{array}$ & $\begin{array}{l}\text { 1. "[...] caso surja algum } \\
\text { trabalho de versão para } \\
\text { fazer" } \\
\text { 4. "Costumo escrever nas } \\
\text { anotações dos textos que } \\
\text { leio" }\end{array}$ \\
\hline RE & $\begin{array}{l}\text { 1. Profissional e/ou } \\
\text { acadêmico } \\
\text { 2. Escolar } \\
\text { 3. Comunicativo }\end{array}$ & 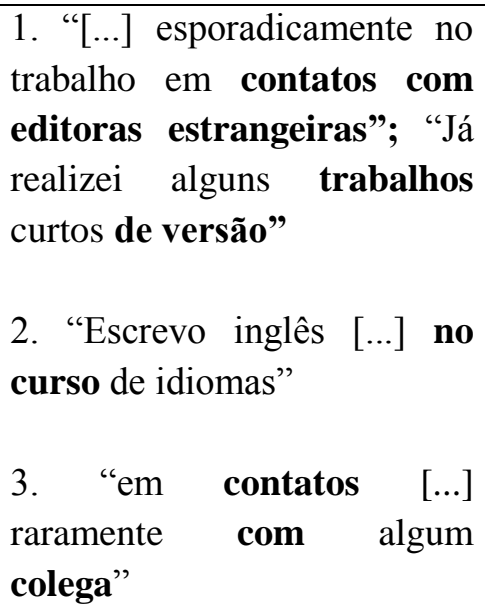 \\
\hline
\end{tabular}




\begin{tabular}{|c|c|c|}
\hline $\mathbf{L U}$ & $\begin{array}{l}\text { 1. Profissional e/ou } \\
\text { acadêmico }\end{array}$ & $\begin{array}{l}\text { 1. "faço alguns relatórios } \\
\text { para a escola onde trabalho" } \\
\text { "Na época da graduação e } \\
\text { pós-graduação escrevia com } \\
\text { maior frequêencia [...]" }\end{array}$ \\
\hline $\mathbf{S A}$ & & $\begin{array}{l}\text { "A minha freqüência atual é } \\
\text { nula }[\ldots] "\end{array}$ \\
\hline
\end{tabular}

A recorrência das categorias de usos está representada na tabela 15 e no gráfico 2 (abaixo):

Tabela 15 - Recorrência das categorias de usos

\begin{tabular}{|l|l|}
\hline Categorias de usos (atual) & $\mathbf{N}^{\mathbf{0}}$ de alunos \\
\hline Profissional e/ou acadêmico & $3(\mathbf{N A} ; \mathbf{R E} ; \mathbf{L U})$ \\
\hline Escolar & $1(\mathbf{R E})$ \\
\hline Comunicativo & $1(\mathbf{R E})$ \\
\hline Cognitivo & $1(\mathbf{N A})$ \\
\hline
\end{tabular}




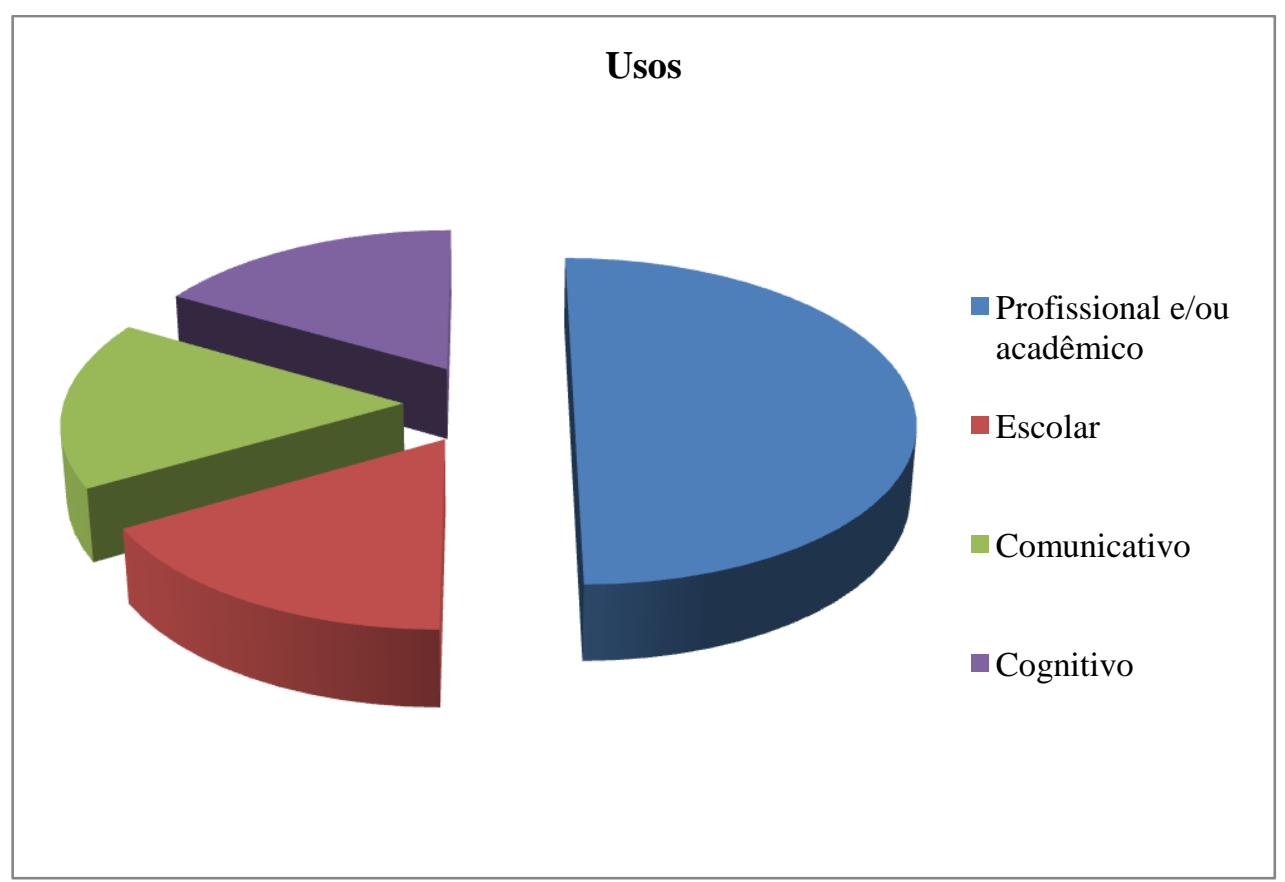

Gráfico 2 - Recorrência das categorias de usos

Conforme mostra a tabela 14, na época do curso, apenas três alunas escreviam em inglês: NA, LU e RE. NA utilizou expressões que incluímos nas categorias 'profissional e/ou acadêmico' e 'cognitivo'. RE utilizou expressões relacionadas às categorias 'profissional e/ou acadêmico', 'escolar' e 'comunicativo'. E, finalmente, LU utilizou expressões referentes apenas à categoria 'profissional e/ou acadêmico'. A categoria 'profissional e/ou acadêmico' foi, portanto, a que mais se destacou. Apenas uma aluna (NA) mencionou o uso 'cognitivo' e a mesma aluna (RE) os usos 'escolar' e 'comunicativo'.

As três outras participantes, que disseram não estar escrevendo no momento (MA, DI e SA), já escreveram no passado. As expressões por elas utilizadas e as informações que temos sobre seu perfil indicam usos da escrita categorizados como 'escolar' e 'profissional e/ou acadêmico'. Todas elas, muito provavelmente, tiveram que escrever compositions nas aulas de inglês que frequentaram (uso categorizado como 'escolar'). MA, que é mestre em sua área, certamente, precisou escrever o abstract de sua dissertação. DI explica que não escreveu mais porque saiu da área da pesquisa de 
alto nível, deixando, dessa forma, subtendido que já utilizou a escrita em inglês na academia. E, finalmente, SA, que está fazendo doutorado em sua área (Engenharia Química), provavelmente, precisou escrever o abstract de sua dissertação e de possíveis artigos que possa ter publicado. Todos esses casos referem-se à categoria 'profissional e/ou acadêmico'.

As considerações a respeito desses resultados serão realizadas após a análise das expressões referentes às dificuldades, quando faremos a segunda triangulação das informações obtidas (objetivos x perfil x usos x dificuldades).

\subsubsection{Categorização das dificuldades}

As dificuldades mencionadas pelas alunas foram categorizadas conforme a tabela 16 (abaixo):

Tabela 16 - Categorização das dificuldades

\begin{tabular}{|c|c|}
\hline Categorias de dificuldades & Exemplos \\
\hline 1. Gramática & $\begin{array}{l}\text { MA: "incerteza em relação às estruturas"; } \\
\text { DI: “[...] e gramática” } \\
\text { NA: “[...] questão de gramática” } \\
\text { RE: "Sinto dificuldade mais na hora de adotar } \\
\text { uma construção mais adequada [...]" }\end{array}$ \\
\hline 2. Vocabulário & $\begin{array}{l}\text { MA: "Falta de vocabulário" } \\
\text { DI: "Penso q vocabulário }[\ldots] " \\
\text { NA: "falta de treino com o vocabulário" } \\
\text { RE: "Sinto dificuldade }[\ldots] \text { com um } \\
\text { vocabulary }[\ldots] " \\
\text { LU: "Acho que as maiores dificuldades são } \\
\text { quanto ao vocabulário }[\ldots] "\end{array}$ \\
\hline 3. Fluência & $\begin{array}{llll}\text { NA: } & \text { "...] tenho dificuldade } & \text { com } & \text { a } \\
\text { espontaneidade em escrever" } & & \\
\end{array}$ \\
\hline
\end{tabular}


4. Bloqueio psicológico

SA: "É muito doloroso começar e sempre tenho desculpas para não continuar"

A tabela 17 (abaixo) apresenta as categorias de dificuldades em relação às participantes e as expressões utilizadas.

Tabela 17 - Participantes e suas dificuldades

\begin{tabular}{|c|c|c|}
\hline Participantes & Categorias de dificuldades & Expressões utilizadas \\
\hline MA & $\begin{array}{l}\text { 1. Gramática } \\
\text { 2. Vocabulário }\end{array}$ & $\begin{array}{l}\text { 1. "incerteza em relação às } \\
\text { estruturas" } \\
\text { 2. "Falta de vocabulário" }\end{array}$ \\
\hline DI & $\begin{array}{l}\text { 1. Gramática } \\
\text { 2. Vocabulário }\end{array}$ & $\begin{array}{l}\text { 1. "[...] e gramática" } \\
\text { 2. "Penso q vocabulário [...]" }\end{array}$ \\
\hline $\mathbf{N A}$ & $\begin{array}{l}\text { 1. Gramática } \\
\text { 2. Vocabulário } \\
\text { 3. Fluência }\end{array}$ & $\begin{array}{l}\text { 1. "[...] questão de } \\
\text { gramática" } \\
\text { 2. "falta de treino com o } \\
\text { vocabulário" } \\
\text { 3. "[...] tenho dificuldade } \\
\text { com a espontaneidade em } \\
\text { escrever" }\end{array}$ \\
\hline $\mathbf{R E}$ & $\begin{array}{l}\text { 1. Gramática } \\
\text { 2. Vocabulário }\end{array}$ & $\begin{array}{l}\text { 1. "Sinto dificuldade mais na } \\
\text { hora de adotar uma } \\
\text { construção mais adequada } \\
{[\ldots] "} \\
\text { 2. "Sinto dificuldade }[\ldots] \text { com } \\
\text { um vocabulary }[\ldots] \text { "... }\end{array}$ \\
\hline $\mathbf{L U}$ & 2. Vocabulário & $\begin{array}{l}\text { 2. "Acho que as maiores } \\
\text { dificuldades são quanto ao } \\
\text { vocabulário [...]" }\end{array}$ \\
\hline $\mathbf{S A}$ & 4. Bloqueio psicológico & 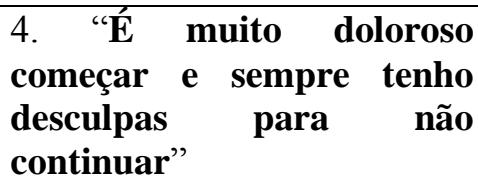 \\
\hline
\end{tabular}


A tabela 18 e o gráfico 3 (abaixo) apresentam a recorrência das categorias de dificuldades entre as participantes.

Tabela 18 - Recorrência das categorias de dificuldades

\begin{tabular}{|l|l|}
\hline Categorias de dificuldades & $\mathbf{N}^{\mathbf{0}}$ de alunos \\
\hline Gramática & 4 (MA; DI; NA; RE) \\
\hline Vocabulário & 5 (MA; DI; NA; RE; LU) \\
\hline Fluência & 1 (NA) \\
\hline Bloqueio psicológico & $1($ SA $)$ \\
\hline
\end{tabular}

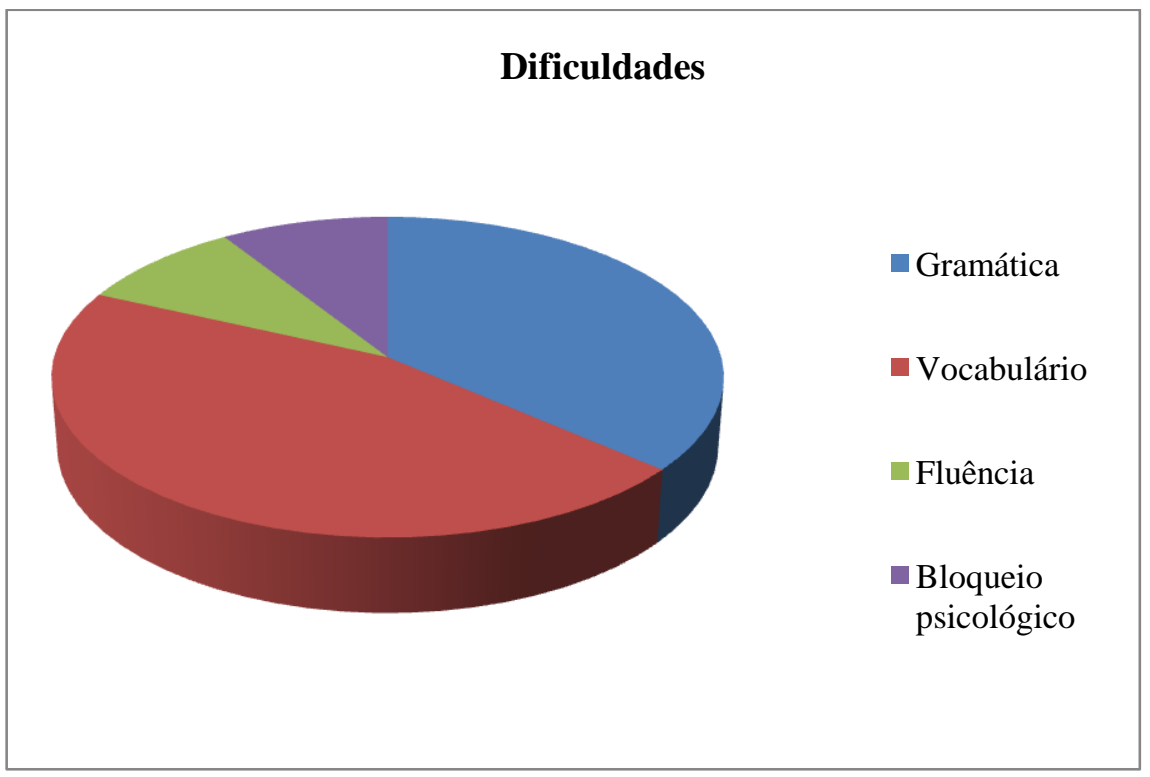

Gráfico 3 - Recorrência das categorias de dificuldades

A maioria das expressões utilizadas pelas participantes para se referirem às suas dificuldades relacionam-se à gramática e/ou a vocabulário. As categorias 'gramática' e vocabulário' representam, dessa forma, as dificuldades apontadas pelas participantes em relação a esses dois aspectos da língua. As categorias 'fluência' e 'bloqueio psicológico' foram criadas para representar a natureza das dificuldades mencionadas pelas alunas, NA e SA, respectivamente. NA explica que tem "[...] dificuldade com a 
espontaneidade em escrever", o que consideramos um problema de fluência. SA descreve sua dificuldade como uma forma de bloqueio psicológico (“'́́ muito doloroso começar e sempre tenho desculpas para não continuar").

As considerações a respeito desses dados serão realizadas, a seguir, juntamente com os dados referentes aos usos e ambos em suas relações com os dados sobre os objetivos, procedendo, dessa forma, à segunda triangulação das informações obtidas.

\subsubsection{Considerações preliminares referentes aos usos, dificuldades e sua relação com os objetivos e perfil das participantes (tabelas 7 e 8)}

Nas considerações preliminares referentes aos objetivos das participantes (item 4.1.1.2.), levantamos a hipótese de que suas concepções de língua e escrita estariam, provavelmente, ligadas à abordagem tradicional de ensino da escrita, que, concebe a língua como um sistema de códigos, desvinculada do indivíduo e de suas práticas sociais, e a escrita como imitação de textos considerados bons, com foco na gramática (Ferreira, 2011). Chegamos a essa conclusão por considerar que essas concepções poderiam explicar, por um lado, a recorrente preocupação de algumas alunas (neste caso, a maioria) com questões ligadas, exclusivamente, à gramática e a vocabulário e, por outro, o uso de expressões negativas em relação à escrita, considerando-se seu perfil de profissionais da área de Letras ou pós-graduadas de outras áreas.

$\mathrm{Na}$ análise dos dados sobre os usos e dificuldades mencionados pelas participantes, essa hipótese se confirma. De um modo geral, dois aspectos foram fundamentais para chegarmos a essa conclusão: 1) a maioria das alunas menciona dificuldades relacionadas, especificamente, à gramática e/ou a vocabulário; 2) apenas três alunas escreviam em inglês na época do curso, mas todas, sem exceção, escreveram em inglês nos cursos de idiomas que frequentaram. 
Apesar de NA, RE e LU estarem efetivamente usando a escrita na época do curso ("Costumo escrever nas anotações dos textos que leio" (NA); “[...] em contatos com editoras estrangeiras" (RE); "faço alguns relatórios para a escola onde trabalho" (LU)) e de MA, DI e SA expressarem seu interesse em utilizá-la de modo significativo em seu dia-a-dia ("Não tenho usado mais pq saí da área de pesquisa de alto nível” (DI); "A minha freqüência atual é nula e já me prejudiquei, pois deixei de publicar [...]" (SA)), quando questionadas sobre suas dificuldades, a maioria menciona aspectos relacionados à gramática e vocabulário.

Essa contradição entre o perfil das alunas e os usos que fazem da escrita (ou que esperam fazer), por um lado, e aquilo que acreditam serem suas dificuldades, por outro, revelam uma divergência entre ações (usos e perspectivas de uso) e concepções. Apesar de utilizarem (ou objetivarem utilizar) a escrita em atividades prático-cognitivas autênticas no mundo, as participantes mantêm uma concepção tradicional de língua e escrita que as impedem de ligar a utilidade e a importância da escrita em suas vidas ao conhecimento que ainda precisam adquirir sobre ela, que não se restringe, obviamente, ao vocabulário e à gramática, como uma concepção tradicional de língua e escrita faz acreditar.

Essa divergência entre crenças e ações, segundo Woods (1996), se deve à existência de dois tipos de crenças: "crenças abstratas" e "crenças em ação". As crenças abstratas são aquelas que o indivíduo tem consciência e as crenças em ação são aquelas subjacentes às suas ações. Segundo o autor, a discrepância entre ações e crenças ocorre quando "uma unidade de comportamento torna-se uma rotina inconsciente de forma não analisada" (p. 27). Entendemos que as respostas das alunas em relação aos usos refletem suas crenças em ação enquanto que suas respostas em relação aos seus objetivos e dificuldades refletem suas crenças abstratas. 
O fato de todas as alunas terem frequentado escolas de idiomas, por sua vez, constitui o segundo aspecto fundamental para a identificação de suas concepções, uma vez que estudos recentes sobre a escrita em inglês (FERREIRA, 2011; RIOS, 2010) revelam práticas de ensino fundamentadas em abordagens tradicionais e até prétradicionais (FERREIRA, 2011) nesse contexto. Rios (2010), por exemplo, mostra como a escrita é, muitas vezes, concebida como simples instrumento para se trabalhar a oralidade, sendo, consideravelmente, menos focalizada e valorizada. Os estudos sobre crenças (BARCELOS; VIEIRA-ABRAHÃO, 2006; SILVA, 2010), por sua vez, chamam atenção para o fato de que práticas influenciam crenças (e vice-versa) e de que crenças de professores influenciam crenças de alunos (e vice-versa), podendo levar, dessa forma, a um ciclo vicioso que, a nosso ver, explica (e também confirma nossa hipótese sobre) as concepções tradicionais de língua e escrita das alunas. Nesse ponto, apresentaremos a situação de cada aluna em relação ao que acabamos de discutir, ou seja, em relação à confirmação da hipótese sobre as concepções de língua e escrita das alunas a partir da segunda triangulação das informações obtidas.

A aluna MA, que não havia apresentado nenhum objetivo categorizado como ‘escolar' ou utilizado expressões negativas em relação à escrita, quando diretamente questionada sobre suas dificuldades para escrever, mencionou aspectos ligados à gramática e vocabulário, confirmando assim a hipótese, levantada na primeira triangulação de dados, de que seu interesse pela metodologia "para ajudar um aluno" (objetivo categorizado como 'profissional e/ou acadêmico) revelava um problema que ela mesma pudesse ter com a escrita. Ao ligar suas dificuldades apenas à gramática e vocabulário ("incerteza em relação às estruturas", "Falta de vocabulário"), apesar de todo conhecimento adquirido ao longo de sua vida como aluna e professora de inglês, 
MA revela uma concepção tradicional de língua, escrita e seu ensino, voltado, como vimos, ao treinamento desses aspectos da língua.

A aluna DI, que também não havia apresentado objetivos categorizados como 'escolar', mencionou questões de gramática e vocabulário para se referir às suas dificuldades ("Penso q vocabulário e gramática (...)”). Além disso, expressou sentimentos negativos em relação à escrita, demonstrando desconforto e insegurança, por um lado, e o desejo de sentir-se melhor e mais confiante para escrever, por outro (“feel well to write", "quero me sentir mais segura para escrever").

O interesse pelo aprendizado de gramática e/ou vocabulário, bem como a expressão de sentimentos negativos em relação à língua (neste caso, com exceção apenas de $\mathbf{L U}$ ) aparecem tanto nos dados sobre objetivos (tabela 10) como nos dados sobre dificuldades (tabelas 17, neste caso com exceção apenas de SA) de todas as demais alunas.

Em relação aos dados sobre os usos (tabela 14), outro aspecto a ser destacado, além do já mencionado (sobre a experiência que as participantes tiveram com a escrita em escolas de idiomas), diz respeito ao fato de todas terem apresentado as categorias 'escolar' e 'profissional e/ou acadêmico' e apenas duas terem mencionado usos categorizados como 'comunicativo' (RE: “em contatos [...] com algum colega") e ‘cognitivo' (NA: “Costumo escrever nas anotações dos textos que leio”). Podemos dizer que a recorrência da categoria 'escolar' representa a experiência das participantes como alunas e/ou professoras de inglês. A categoria 'profissional e/ou acadêmico' representa o uso efetivo da língua pelas alunas na academia ou no ambiente de trabalho (atualmente ou no passado). As categorias 'comunicativo' e 'cognitivo', por sua vez, com recorrência quase nula, representam o uso da língua em situações não formais e como instrumento para a realização de atividades cognitivas no dia-a-dia como, por 
exemplo, 'conversar' pela internet ou fazer anotações para entender melhor um texto. Acreditamos que a ausência quase total desses dois tipos de usos da língua estrangeira em questão, diferentemente do que acontece com a língua materna, em outras palavras, de usos da língua em situações autênticas de comunicação e/ou de sua utilização como instrumento em atividades cognitivas no dia-a-dia, contribui para reforçar concepções tradicionais de língua e escrita e para o desenvolvimento de sentimentos negativos como os apresentados nos dados das participantes e que, por sua vez, não aparecem em relação à língua materna como mostra a tabela 19 (abaixo) que apresenta as expressões negativas utilizadas pelas alunas ao longo de todo o curso em relação ao inglês e suas opiniões em relação ao seu desempenho na escrita em português.

Tabela 19 - Sentimentos em relação à escrita em inglês e desempenho em língua materna (Fonte: EP; FI; DD)

\begin{tabular}{|c|c|c|}
\hline Nomes & $\begin{array}{l}\text { Sentimentos em relação à } \\
\text { escrita em inglês }\end{array}$ & $\begin{array}{l}\text { Desempenho em língua } \\
\text { materna }\end{array}$ \\
\hline MA & 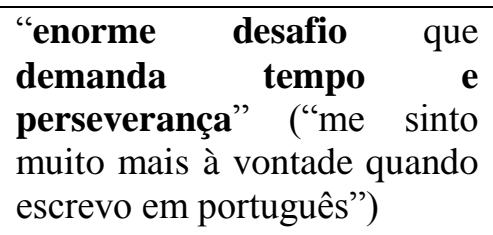 & 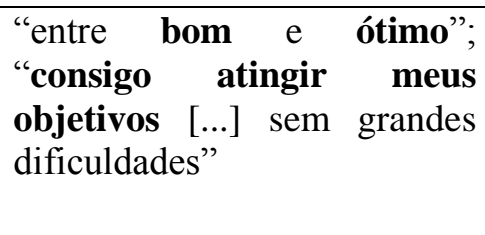 \\
\hline DI & $\begin{array}{l}\text { "senti medo"; "tenho um } \\
\text { medo da-na-do de errar"; } \\
\text { "tenho preguiça"; "ter que } \\
\text { procurar palavras é } \\
\text { cansativo"; "quero me } \\
\text { sentir mais segura para } \\
\text { escrever" ("escrever na língua } \\
\text { materna eu ADOOORO!É q, } \\
\text { na verdade, gosto de me } \\
\text { expressar!! Por escrito tb!") }\end{array}$ & $\begin{array}{l}\text { "As pessoas }[\ldots] \text { costumam } \\
\text { elogiar e entender" }\end{array}$ \\
\hline $\mathrm{NA}$ & $\begin{array}{l}\text { "me causa }[\ldots] \text { um certo } \\
\text { desconforto"; "É } \\
\text { atividade bem } \\
\text { espontânea do que a escrita } \\
\text { em português, com a qual } \\
\text { me sinto bem mais à } \\
\text { vontade." }\end{array}$ & $\begin{array}{l}\text { "Acho que tenho uma boa } \\
\text { escrita em português }[\ldots . .] "\end{array}$ \\
\hline
\end{tabular}




\begin{tabular}{|c|c|c|}
\hline $\mathrm{RE}$ & $\begin{array}{l}\text { "[...] um pouco ansiosa"; } \\
\text { "Apesar de até hoje } \\
\text { frequentar aulas regulares de } \\
\text { língua inglesa em uma escola } \\
\text { de idiomas, não sinto uma } \\
\text { segurança total na hora de } \\
\text { redigir para um native- } \\
\text { speaker, por exemplo, ou } \\
\text { muito menos verter um texto } \\
\text { para o inglês"; "[...] depende } \\
\text { da situation. Quando escrevi } \\
\text { sobre o filme Freedom } \\
\text { Writers, que vimos na } \\
\text { segunda aula, por exemplo, } \\
\text { me senti a vontade para usar o } \\
\text { inglês. Parecia que eu não } \\
\text { estava under pressure, e me } \\
\text { soltei para usar o que eu } \\
\text { sabia. Foi natural. Quase } \\
\text { não acreditei!" }\end{array}$ & $\begin{array}{l}\text { "Considero ter um bom } \\
\text { desempenho na escrita em } \\
\text { língua portuguesa." }\end{array}$ \\
\hline LU & $\begin{array}{l}\text { "[...] fiquei em dúvida }[. . .] \text { se } \\
\text { conseguiria expor o que } \\
\text { desejava." }\end{array}$ & "[...] entre bom e razoável" \\
\hline SA & $\begin{array}{l}\text { "[...] mesmo com um } \\
\text { dicionário do lado e com } \\
\text { acesso à internet, sinto-me } \\
\text { desconfortável para redigir } \\
\text { em inglês. Portanto, não } \\
\text { conheço o real motivo para } \\
\text { este desconforto."; "[...] } \\
\text { tenho muitas dificuldades. É } \\
\text { muito doloroso começar e } \\
\text { sempre tenho desculpas para } \\
\text { não continuar"; "Considero } \\
\text { que tenho certo bloqueio para } \\
\text { a escrita" }\end{array}$ & $\begin{array}{l}\text { "[...] considerarei o meu } \\
\text { desempenho bom } \\
\text { tímido)." }\end{array}$ \\
\hline
\end{tabular}

Na segunda etapa da análise, que se iniciará logo após a discussão dos resultados dessa primeira parte, investigaremos se ocorre ou não mudança nas concepções de língua e escrita das alunas que, como vimos, estão ligadas à abordagem tradicional de ensino da escrita, abordagem pela qual provavelmente foram ensinadas.

\subsubsection{Discussão dos resultados da $1^{\text {a }}$ etapa da análise (tabelas 7 e 8)}


Em um estudo recente sobre o livro didático importado de inglês e o ensino da escrita, Ferreira (2011) chama a atenção para o modo mecânico e descontextualizado como a escrita é trabalhada em um livro bastante conhecido e utilizado em cursos de idiomas no Brasil. Rios (2010), por sua vez, investigando práticas de ensino da escrita em um conceituado instituto de idiomas no estado de São Paulo, apresenta resultados que revelam uma desvalorização da escrita em relação às demais habilidades, tanto por parte do professor e do aluno, como do livro didático.

Esses e outros estudos sobre o ensino do inglês em escolas públicas (MOTTA, 2007; SILVA, 2010) alertam para a necessidade da promoção de um ensino significativo, que aborde a língua como prática social e, dessa forma, contribua para a promoção do letramento crítico, fundamental para a formação de indivíduos capazes de atuar de maneira responsável, ética e democrática na sociedade (ROJO, 2009). Diante desse quadro, entendemos que as concepções tradicionais de língua e escrita apresentadas pelas participantes nesse estudo são, provavelmente, consequência dessas práticas de ensino fundamentadas em abordagens tradicionais e até pré-tradicionais, por meio das quais foram ensinadas.

As consequências dessa desvalorização do ensino da escrita, por sua vez, são, no mínimo, preocupantes. As concepções tradicionais que esse tipo de ensino tem promovido entre os aprendizes de inglês e estudantes de um modo geral, os privam da experiência de utilizarem a escrita de modo significativo em seu dia-a-dia e, consequentemente, da possibilidade de participarem de modo mais efetivo na sociedade atual, altamente globalizada e marcada pela diversidade linguística e cultural (GEE, 2000; LANKSHEAR; KNOBEL, 2003; LUKE, 2000). 
Outro aspecto importante e que deve ser levado em consideração diz respeito ao fracasso das atuais práticas de ensino da escrita (fundamentadas em concepções tradicionais de língua e escrita como mostram as citadas pesquisas) na tarefa de promover o aprendizado dessa habilidade, gerando, conforme vimos neste estudo, sentimentos negativos em relação à língua que acabam se tornando, por sua vez, mais um agravante no processo de ensino-aprendizagem. Como é possível inferir dos resultados dessa primeira etapa da análise, esses sentimentos são consequências, por um lado, 1) da crença (gerada, por sua vez, pelas práticas pautadas nas abordagens tradicionais de ensino) de que nunca dominarão completamente o idioma, já que para isso precisariam estar constantemente treinando e adquirindo mais e mais conhecimentos de gramática e vocabulário da língua e, por outro lado, 2) da ineficácia dessas práticas que geram, por sua vez, as dificuldades enfrentadas pelos alunos quando precisam (ou querem ) escrever em inglês ${ }^{26}$.

Poderíamos supor que o uso dessas expressões negativas pudesse ser reflexo de um problema com a escrita de um modo geral, no entanto, dados sobre seu desempenho em língua materna, como vimos há pouco (tabela 19), mostram uma relação tranquila em relação à escrita em português, o que, obviamente, não pode ser generalizado em relação a outros aprendizes de inglês, uma vez que os participantes dessa pesquisa são estudiosos da língua ou profissionais que utilizam a língua academicamente. Dessa forma, acreditamos que esses sentimentos negativos de "medo", "insegurança", “desconforto", "desafio", “dor", entre outros, são provenientes também, conforme mencionamos anteriormente, da falta de usos significativos da língua estrangeira no dia-

\footnotetext{
${ }^{26}$ Em seu artigo, Ferreira (2011) sugere "alternativas para a criação e implementação de currículos de ensino de LE mais inovadores e democráticos que promovam uma aprendizagem de LE mais relevante e condizente às necessidades dos aprendizes".
} 
a-dia, como ocorre em língua materna, por exemplo, para comunicação em situações informais do dia-a-dia ou, pelo menos, em situações diferentes do contexto escolar.

Nesse ponto da discussão, é fundamental chamar atenção para a importância do conceito de crenças no ensino e aprendizagem de línguas, neste caso, especificamente, da escrita em inglês. Segundo Woods (2003), a importância de crenças tem sido subestimada na área do ensino e aprendizagem de línguas. Barcelos e Vieira-Abrahão (2006) chamam a atenção para a complexidade desse conceito e explica que ela é resultado da relação intrínseca entre crenças, ações e contexto. A reconhecida influência das crenças sobre as ações (como, por exemplo, nas práticas dos professores de línguas) e das crenças de alunos sobre as crenças de professores e vice-versa, levam, conforme já mencionamos, a um ciclo vicioso que resulta em uma realidade difícil de ser transformada (MICCOLI, 2010). Diante desse quadro e como indicam os resultados da primeira etapa desse estudo, o conceito de crenças é fundamental no processo de ensino e aprendizagem de línguas e deve ser conscientemente e com rigor teórico considerado nas práticas de ensino de línguas de um modo geral, especialmente, quando o foco é o desenvolvimento cognitivo dos alunos, como foi o caso do curso que serviu de base para esta pesquisa.

Do ponto de vista da perspectiva sócio-histórico-cultural, além de prática social, a escrita é considerada instrumento simbólico (um dos mais importantes das sociedades modernas) responsável pela promoção do desenvolvimento psicológico (intelectual) dos indivíduos. Sendo os instrumentos simbólicos (ou psicológicos) fornecidos pelas culturas, podemos dizer que as diferentes práticas de escrita estão diretamente relacionadas ao modo como os indivíduos concebem escrita ou, em outras palavras, às crenças sobre ela (e, acrescentamos, sobre a língua de um modo geral) formadas ao longo de suas vidas (ontogênese). Nesse sentido, torna-se fundamental, no processo de 
ensino-aprendizagem da escrita, a análise das concepções (ou crenças) de língua e escrita dos alunos de modo que seja possível identificar seu nível de desenvolvimento real (sua capacidade de domínio e utilização dessa modalidade da língua) e, dessa forma, criar zonas de desenvolvimento potenciais (por meio de ações que promovam novas formas de conceber língua e escrita) levando à promoção do seu desenvolvimento psicológico (intelectual).

\section{2. $2^{\mathrm{a}}$ etapa da análise}

Conforme mencionado no capítulo anterior, o objetivo dessa segunda etapa da análise é verificar se ocorre ou não mudança nas concepções de língua e escrita das participantes ao longo do curso. Os diários constituíram, nessa etapa, a principal fonte de dados (cf. tabela 2). No entanto, conforme sugerem Cumming e Nassaji (2000) ${ }^{27}$, o contexto em que foram produzidos também foi levado em consideração e, dessa forma, os planos e relatórios de aula também constituíram, ainda que de forma secundária, fontes de dados para essa etapa da pesquisa. Segundo esses autores, que igualmente analisaram diários em sua pesquisa, levar em consideração elementos do contexto garante uma interpretação mais completa e coerente dos dados.

Nos diários, em que estão os depoimentos ${ }^{28} \mathrm{e}$ as respostas das alunas às questões propostas pela instrutora a partir das atividades desenvolvidas nas aulas (enviadas e respondidas por e-mail), procuramos identificar as palavras e/ou expressões que indicassem mudanças relacionadas aos seguintes aspectos: 1) suas motivações em relação ao curso e à escrita, 2) suas principais dificuldades em relação à escrita e 3) suas

\footnotetext{
${ }^{27}$ Os autores analisam as interações em diários dialogados entre uma criança estrangeira aprendendo inglês e sua professora canadense a partir de uma perspectiva vygotskiana.

${ }_{28}$ Nos diários, além de responder às perguntas feitas pela instrutora, as alunas podiam escrever o que quisessem sobre as aulas, como suas impressões, dúvidas, sugestões, elogios e críticas.
} 
definições de conceitos relacionados à língua. Nos planos e relatórios de aula, consideramos especificamente as informações relacionadas aos assuntos tratados nos diários.

Diferentemente da primeira etapa da análise, em que os dados puderam ser, com razoável facilidade, organizados em tabelas e gráficos, os dados dessa segunda etapa encontram-se organizados de maneira mais complexa, variando em quantidade e aprofundamento de assunto de aluno para aluno. Dessa forma, primeiramente, descreveremos e teceremos algumas considerações sobre as atividades desenvolvidas nas aulas (e que serviram de base para a produção dos diários) e, em seguida, analisaremos os dados produzidos por cada aluna separadamente. Nesse sentido, buscamos não apenas identificar a ocorrência de mudança nas concepções das participantes, mas analisar o processo como um todo, ou seja, as condições e possíveis fatores propiciadores dessas mudanças. Ao final, apresentamos um quadro geral a partir do qual propomos algumas questões para discussão.

\subsubsection{Atividades realizadas nas aulas e ações desenvolvidas pela instrutora para promover a mudança nas concepções de língua e escrita dos alunos}

Fundamentado nos pressupostos da abordagem conceitual (FERREIRA, 2005, 2009; FERREIRA; LANTOLF, 2008), o principal objetivo do curso implementado para essa pesquisa era promover o pensamento teórico dos alunos por meio do ensino de gênero textual como conceito científico e manifestação do $A C P^{29}$. Para isso, conforme exposto na fundamentação teórica desse trabalho, a instrutora deveria realizar algumas

\footnotetext{
${ }^{29} A C P$ refere-se ao "Abstract Communicative Principle", que corresponde, por sua vez, à relação dialética entre língua, indivíduo e sociedade, também representada pela expressão 'língua-contexto' e que deve constituir o foco do ensino segundo a abordagem conceitual (FERREIRA, 2005).
} 
ações dentre as quais uma correspondia à apresentação de uma questão-problema que objetivava levar os alunos a perceber a necessidade da aprendizagem daquilo que o curso se propunha a ensinar, ou seja, o $A C P$. Nesse sentido, objetivava-se ensinar gênero textual não como simples modelo a ser seguido, mas como uma ferramenta simbólica para a produção contextualizada e significativa de textos.

No entanto, a questão-problema ${ }^{30}$ planejada para o curso e que se pretendia apresentar aos alunos fundamentava-se e previa a existência de concepções menos tradicionais de língua e escrita do que a apresentada por eles no início do curso. Esperava-se que os alunos demonstrassem uma noção mais clara da relação entre língua, indivíduo e sociedade, ou, em outras palavras, que enxergassem a língua (e a escrita), pelo menos, como prática social ${ }^{31}$. Em decorrência desse imprevisto, o foco das aulas mudou e além das ações previstas na abordagem conceitual, novas ações foram desenvolvidas $^{32}$, objetivando a mudança em suas concepções de língua e escrita ${ }^{33}$. Essas novas ações basearam-se, principalmente, em questionamentos e reflexões com os alunos sobre 1) suas dificuldades e reais necessidades de aprendizagem e uso da escrita e 2) sobre a língua e a escrita de um modo geral. Esse procedimento adotado pela instrutora encontra respaldo tanto nos estudos sobre crenças que focalizam a mudança nas concepções dos agentes envolvidos nos processos de ensino e aprendizagem (BARCELOS, 2007), como nos princípios da perspectiva vygotskiana (VYGOTSKY, 1978, 1987).

\footnotetext{
${ }^{30}$ Questão-problema: We use language in a variety of situations and to achieve a wide range of goals.How do we use language to achieve these goals? How does the social situation affect our use of language?

${ }^{31}$ Além de prática social, de um ponto de vista da perspectiva sócio-histórico-cultural, a escrita constitui um importante instrumento simbólico utilizado em atividades práticas e cognitivas no mundo.

${ }^{32} \mathrm{O}$ objetivo principal de promover o pensamento teórico dos alunos bem como a aplicação das ações pedagógicas previstas na abordagem conceitual foram mantidos, no entanto, não chegaram a ser concluídos em decorrência da curta duração do curso que não havia antecipado esse imprevisto.

${ }^{33}$ De acordo com Barcelos (2007), há contextos em que a mudança de crenças é desejável e, nesse sentido, deve constituir o foco do ensino, como ocorreu no contexto dessa pesquisa.
} 
Do ponto de vista da perspectiva vygotskiana, o uso da linguagem como instrumento para reflexão e construção do conhecimento, reflete o princípio da mediação e da promoção do desenvolvimento por meio de instrumentos simbólicos (sendo a linguagem o principal deles), fundamental dentro dessa perspectiva e presente em vários estudos nessa linha dentro da Linguística Aplicada (MAGALHÃES, 2002, 2004, 2007; MEANEY, 2009, entre outros).

A maioria dos estudos sobre crenças com foco na mudança (ARAÚJO, 2004; BLATYTA,1999; PESSOA; SEBBA, 2006; PITELI, 2006, entre outros), por sua vez, sugere a reflexão e a explicitação das crenças como fatores fundamentais para que a mudança ocorra. Segundo Woods (2003), para que a mudança nas crenças ocorra é necessário torná-las explícitas para análise, exame e reflexão. Segundo Barcelos (2007), de acordo com Pajares (1992), “a pessoa precisa perceber suas próprias crenças como insatisfatórias. Isso acontece quando suas crenças são desafiadas (...)” (p.119). Normalmente, os estudos sobre crenças focalizam a mudança nas crenças de professores, objetivando mudanças em suas práticas (ARAÚJO, 2006; DUTRA; OLIVEIRA, 2006; PESSOA; SEBBA, 2006). No entanto, o perfil dos alunos deste curso não apenas permitiu, mas mostrou-se coerente com esse tipo de intervenção, uma vez que todas as participantes eram pós-graduadas e/ou profissionais da área e, portanto, capacitadas e habituadas à prática da reflexão.

Com o objetivo de tornar explícitas e, ao mesmo tempo, questionar (desafiar) as crenças das alunas (nesse caso, crenças sobre suas dificuldades e, consequentemente, sobre suas reais necessidades de aprendizagem), as reflexões e os questionamentos promovidos pela instrutora tiveram como base 1) as experiências das alunas com a escrita, 2) textos teóricos sobre a escrita e 3) exercícios em geral, incluindo atividades de leitura de amostras de gêneros e produção textual. Nesse ponto, 
apresentaremos as atividades realizadas em sala de aula e que constituíram o contexto das reflexões promovidas nos diários.

A primeira atividade realizada pelos alunos em sala de aula correspondeu à produção de um texto argumentativo, aplicado como instrumento de avaliação diagnóstica. Após a realização dessa atividade, a instrutora propôs as seguintes perguntas em seus diários:

1) Como você se sentiu quando a instrutora disse que após o intervalo vocês fariam uma atividade de produção textual em forma de teste? Como você se sente quando tem que escrever em inglês? E na sua língua materna? Qual a diferença?

2) Como foi durante o processo de escrita do texto? O que você fez primeiro? Você usou a folha de rascunhos? Para quê, exatamente: para anotar suas idéias ou para escrever o texto e depois corrigi-lo?

3) Quais foram as suas principais dificuldades na hora de escrever (organizar as idéias, definir uma opinião em relação ao assunto do texto, falta de vocabulário, falta de conhecimento gramatical para desenvolver as idéias etc)?

Ao colocar essas questões, o objetivo da instrutora era levar os alunos a exporem seus sentimentos e a refletirem sobre suas reais necessidades/dificuldades em relação à escrita a partir de uma experiência recente com ela. Esperava-se que eles percebessem outros problemas, além de gramática e vocabulário, e começassem a refletir sobre as origens dos sentimentos ruins que acompanhavam suas experiências com a escrita. Essas questões visavam, também, desenvolver nos alunos o auto-controle do seu 
processo de aprendizagem, aspecto previsto na abordagem conceitual (FERREIRA, 2005), em que o curso se fundamentou.

A segunda atividade de reflexão e questionamento desenvolvida nos diários baseou-se na apresentação dos materiais de apoio pela instrutora que se referiu a gramáticas, manuais e dicionários como ferramentas para serem consultadas quando necessário e não como objeto ou conteúdo do curso. Esperava-se, dessa forma, desestabilizar (ou questionar) a idéia de ensino da escrita como sinônimo de treinamento de gramática e vocabulário, bem como do papel da instrutora como simples corretora de erros. Por outro lado, essa ação objetivou criar uma expectativa (uma dúvida), positiva segundo os estudos com foco em mudanças de crenças ${ }^{34}$, sobre o que constituiria, então, o conteúdo do curso. Nos diários a instrutora deixou-os livre para fazer comentários, colocando-se da seguinte forma:

Se você tiver mais algum comentário sobre o uso de materiais ou sobre a primeira parte da aula como um todo, sinta-se à vontade para escrever.

A terceira atividade realizada em aula correspondeu à apresentação do filme "Freedom Writers" que mostra como a leitura e a escrita, a princípio atividades sem sentido na vida de um grupo de estudantes de uma escola pública norte-americana, tornam-se ferramentas fundamentais para mudar suas vidas. Nos diários, a instrutora deixou-os à vontade para expressar o que haviam achado do filme, colocando a seguinte pergunta:

O que você achou do filme? Comente-o.

\footnotetext{
${ }^{34}$ Barcelos (2007) explica que "mudança implica momentos de dúvida, de incerteza, de ambigüidade, já que deixamos algo conhecido para embarcarmos no desconhecido" (p. 115).
} 
A quarta atividade de reflexão nos diários foi baseada na leitura de Foley (1989). Nesse texto, a autora questiona a utilização do modelo "Five-paragraph essay" como referência (e, principalmente, como única referência) para o ensino da escrita. No diário, a instrutora pediu para que emitissem livremente suas opiniões como fez em relação ao filme:

O que você achou do texto da Foley? Comente-o.

As perguntas elaboradas com base nas duas atividades descritas acima foram propositalmente elaboradas de modo vago (não específico) para não influenciar a resposta dos alunos.

Nesse ponto do curso, a instrutora propôs, em sala de aula, uma atividade em grupo em que os alunos deveriam responder as seguintes perguntas:

\section{Make a list in order of importance of what you consider} fundamental to produce a satisfactory piece of writing.

\section{Explain the importance of each item mentioned.}

De um modo geral, chegou-se ao consenso (entre os alunos), de que conhecer a língua-alvo era o elemento mais importante para se produzir um texto e que, em segundo lugar, estava conhecer o assunto que nele seria desenvolvido. É fácil perceber por essas respostas o quanto suas concepções de escrita estão atreladas ao contexto escolar, onde se ensina gramática e vocabulário e sugere-se um tema apenas para demonstração de conhecimento das estruturas ensinadas. Não se percebe em suas falas relação entre escrita e necessidades práticas ou utilização da escrita como prática social, mas apenas como um fim em si mesma ou instrumento de avaliação. 
A partir das respostas das alunas a essas perguntas, a instrutora pôde colocar a questão-problema elaborada especificamente para esse grupo, que não era, como explicamos, a questão-problema planejada para o curso, uma vez que o objetivo anterior à promoção do seu pensamento teórico deveria ser a promoção da mudança de suas concepções de língua e escrita. A questão-problema apresentada foi a seguinte:

Que tipo de conhecimento, enfim, é necessário para se escrever bem? (E, implicitamente, a questão incluía 'escrever bem de maneira tranquila e segura, considerando-se um indivíduo que já possui conhecimento suficiente da língua e, portanto, capaz de consultar gramáticas e dicionários e de adquirir conhecimento sobre os mais diversos assuntos e sobre características de textos por meio da leitura feita diretamente na língua-alvo’)

Após a apresentação dessa questão-problema e da explicação de como a língua deveria ser cientificamente investigada para se chegar à resposta para essa questão, a instrutora desenvolveu em aula uma série de explicações, com participação das alunas que tiravam dúvidas e interagiam dando exemplos de sua experiência, sobre a natureza e as características básicas da língua e da escrita vistas a partir da perspectiva vygotskiana. O objetivo era levá-los a perceber como a língua está diretamente relacionada à "atividade", às ações do ser humano, sendo usada como ferramenta psicológica na solução de problemas e como prática social. A instrutora utilizou, para isso, o exemplo da origem do gesto de apontar, explicando como a língua está ligada às necessidades pessoais e sociais dos indivíduos e como por meio da interação, as relações inter-psicológicas tornam-se intra-psicológicas promovendo o desenvolvimento do indivíduo. Várias questões e dúvidas comuns na área do ensino e aprendizagem de línguas foram levantadas pelas alunas e discutidas a partir da teoria vygotskiana. Em seus diários, a instrutora repetiu as questões colocadas pelas próprias alunas em aula 
com o objetivo de avaliar sua compreensão da explicação dada e proporcionar-lhes mais um momento de reflexão sobre os assuntos tratados em aula, representando, dessa forma, a quinta atividade de reflexão desenvolvida nos diários. As questões foram as seguintes:

1. What's the importance of a summary?

2. Como uma criança aprende a falar? (É possível uma criança aprender duas ou mais línguas ao mesmo tempo? Por quê?)

3. Qual a principal diferença entre a forma como uma criança aprende sua língua materna e como um adulto aprende uma língua estrangeira?

4. O que a aprendizagem de uma ou mais línguas na infância promove na vida de uma criança? (Que impacto o aprendizado da língua tem na vida da criança? Pense no caso das meninas-lobo.)

5. O que é a escrita? É possível aprender a escrever antes de falar? Como você explica a eficácia (a existência) dos cursos de inglês instrumental, por exemplo, que ensinam apenas leitura.

6. Qual a principal vantagem de se estar no país em que sua segunda língua é falada?

7. Como você define um bom falante?

8. E um bom escritor?

9. Por que certos tipos de textos são mais fáceis de escrever do que outros?

10. Por que é importante entendermos a relação língua-contexto? De que forma isso nos fará bons escritores? 
11. O que uma abordagem para o ensino da escrita baseada em modelos pode acarretar?

12. Na sua opinião, o que é gênero? Como surge um gênero?

Por meio da discussão sobre a natureza intrinsecamente social e cognitiva da língua, chegou-se a questão da relação entre língua, indivíduo e sociedade e, dessa forma, a questão-problema anteriormente planejada para o curso:

We use language in a variety of situations and to achieve a wide range of goals.How do we use language to achieve these goals? How does the social situation affect our use of language?

Ao serem questionados sobre como poderiam investigar de modo científico a relação entre língua, indivíduo e sociedade, os alunos foram unânimes em responder 'leitura'. Nesse ponto, no entanto, sua visão de leitura já não era mais a mesma do início do curso como veremos na análise dos dados das participantes.

Nas aulas seguintes, não houve perguntas específicas em seus diários, apenas comentários livres e/ou depoimentos das participantes. As demais atividades desenvolvidas em aula foram as seguintes: 1) leitura de um texto teórico (SELZER, 2004), que explora como os elementos linguísticos constroem os sentidos nos textos e como estes, servem, por sua vez, a diversos propósitos sociais; 2) leitura de amostras do gênero abstract; e 3) explicação dos elementos 'campo', 'relação', 'modo' e 'cultura' e de como eles se relacionam na construção desse gênero. Em seguida, focalizou-se o gênero argumentativo e foram lidos e discutidos três textos teóricos (FULKERSON, 
1996; HYLAND, 1990; e MARTIN, 1989) ${ }^{35}$ e realizada uma análise de amostras de textos argumentativos. As demais atividades desenvolvidas constituíram 1) a exploração dos elementos de campo, relação, modo e cultura a partir de amostras do gênero convite de casamento e 2) um exercício de análise de um texto argumentativo em que os alunos tinham que identificar a tese e os movimentos característicos desse gênero (cf. HYLAND, 1990).

Os alunos ainda tiveram a oportunidade de produzir um modelo germ-cell dos conceitos aprendidos e de participarem de mais uma atividade de produção de textual, realizada no último dia de aula. No entanto, não houve tempo suficiente para discussão ou reflexão a partir dessas atividades. Todas essas atividades constituíram o contexto dos dados produzidos pelas participantes nos diários e que, a partir desse momento, serão analisados separadamente.

\subsubsection{Análise do diário de MA}

Como vimos na primeira etapa da análise, os dados produzidos pela aluna MA revelaram concepções tradicionais de língua e escrita, assim como ocorreu com os dados das demais participantes. Apesar de ter mencionado objetivos coerentes com seu perfil $^{36}$, MA mencionou dificuldades relacionadas à gramática e a vocabulário ("Falta de vocabulário e um pouco de incerteza em relação às estruturas - principalmente uso de preposições e das 'collocations"') e revelou ter escrito em inglês apenas em situações formais de contexto escolar ("Escrevi muito enquanto estudava inglês

\footnotetext{
${ }^{35}$ Estes textos abordam diretamente os aspectos lingüísticos e sociais presentes no texto argumentativo, oferecendo-lhes aporte teórico para entender de que forma o $A C P$ se manifesta concretamente neste gênero.

${ }^{36}$ MA foi professora de inglês em escola de idiomas durante vinte e cinco anos e atualmente é professora universitária na mesma área.
} 
'formalmente', mas agora praticamente não o faço mais"). Nesse sentido, nossa conclusão baseou-se, sobretudo, em seus dados referentes às dificuldades e às informações coletadas sobre sua experiência com a escrita. A partir desse ponto, analisaremos os dados produzidos por MA em seu diário tendo como contexto as atividades realizadas em aula e descritas no item anterior.

Reproduzimos abaixo as respostas de $\mathbf{M A}$ às primeiras perguntas ${ }^{37}$ propostas $^{2}$ pela instrutora referentes à realização da primeira atividade de produção escrita aplicada como avaliação diagnóstica no primeiro dia de aula:

1. Achei muito natural, porque acredito que aprendemos a fazer fazendo. Já esperava escrever bastante neste curso. Naturalmente, me sinto muito mais à vontade quando escrevo em português, por que tenho mais domínio do vocabulário e das estruturas de minha língua materna. Mas escrever é sempre um enorme desafio, que demanda tempo e perseverança.

2. Tenho por hábito investir alguns instantes organizando minhas ideias em tópicos e pensando em como desenvolvê-las. Depois escrevo um primeiro rascunho e a seguir vou 'aparando as arestas', até chegar à versão 'final' - final apenas porque tenho que torná-lo público, porque acho que um texto nunca está acabado.

3. Creio que todos os tópicos têm o seu peso, dependendo do texto a ser escrito. No caso da atividade, minha dificuldade maior foi definir uma opinião.

Além de responder às questões propostas pela instrutora, MA fez a seguinte declaração em seu diário:

\footnotetext{
${ }^{37}$ 1) Como você se sentiu quando a instrutora disse que após o intervalo vocês fariam uma atividade de produção textual em forma de teste? Como você se sente quando tem que escrever em inglês? E na sua língua materna? Qual a diferença? 2) Como foi durante o processo de escrita do texto? O que você fez primeiro? Você usou a folha de rascunhos? Para quê, exatamente: para anotar suas idéias ou para escrever o texto e depois corrigi-lo? 3) Quais foram as suas principais dificuldades na hora de escrever (organizar as idéias, definir uma opinião em relação ao assunto do texto, falta de vocabulário, falta de conhecimento gramatical para desenvolver as idéias etc)?
} 
Ao final do primeiro encontro fiquei com a sensação do grande desafio que você terá para lidar com expectativas tão diferentes quanto as apresentadas pelos participantes do curso. Não me lembro de ter participado de um grupo tão heterogêneo, seja como professora, seja como aluna. Será uma experiência interessante em todos os sentidos.

De minha parte, minha expectativa maior é em relação a material de leitura, conceitos, teorias. Tenho a fluência na língua, tenho longa experiência em sala de aula, mas me falta uma visão mais 'cientifica' dos processos de ensino/aprendizagem, em especial com relação à tendência atual do trabalho a partir de gêneros textuais e em sequências didáticas. $\boldsymbol{O}$ que você puder me indicar a respeito, agradeço DEMAIS!

As expressões usadas por MA na primeira frase de sua resposta à primeira pergunta (Achei muito natural, porque acredito que aprendemos a fazer fazendo. Já esperava escrever bastante neste curso) indicam uma visão de ensino da escrita ligada à treinamento e não produção contextualizada e significativa de textos. MA não demonstrou incômodo ou insatisfação com a possibilidade de ter que escrever outros textos nessa mesma condição ao longo do curso, ou seja, textos desvinculados de uma necessidade prática e que se constituem basicamente de instrumentos de avaliação.

A segunda parte de sua resposta, em relação aos seus sentimentos quando tem que escrever em inglês, MA revela que se sente mais à vontade quando escreve em português e explica que isso se deve ao fato de dominar melhor o vocabulário e as estruturas de sua língua materna (Naturalmente, me sinto muito mais à vontade quando escrevo em português, por que tenho mais domínio do vocabulário e das estruturas de minha língua materna) Novamente, as expressões utilizadas por MA confirmam a existência de concepções tradicionais de língua e escrita, revelando a crença de que a segurança que tem ao escrever em língua materna é proveniente do conhecimento linguístico que dela possui e não da sua utilização em situações significativas e autênticas no dia-a-dia ou de sua identificação com a língua. 
Ao questionar os alunos sobre seus sentimentos quando escreviam (ou tinham que escrever) em inglês, pedindo para que comparassem com suas experiências em língua materna, a instrutora-pesquisadora visava fazê-los perceber a origem desses sentimentos, notadamente, negativos e que, segundo seu ponto de vista, estaria provavelmente ligada, não à falta de conhecimento da língua (como acreditavam), mas aos usos descontextualizados e às situações meramente avaliativas em que a língua estrangeira era, na maioria das vezes (ou, em alguns casos, absolutamente), relacionada. Apesar de em seu primeiro conjunto de dados, MA não ter produzido nenhuma expressão de sentimento negativo em relação à escrita, a insistência nesse aspecto (confirmando o que sugerem os estudos sobre crenças, da necessidade de se tornar as crenças explícitas) resultou, enfim, na utilização de uma expressão negativa por MA que reconheceu a atividade de escrita como "[...] um enorme desafio, que demanda tempo e perseverança". E, finalmente, nesse ponto, acreditamos que se inicia um movimento em direção a uma mudança, considerando como explica Barcelos (2007, p.116) ${ }^{38}$ que a mudança não está necessariamente ou apenas relacionada à modificação de ações, mas também (e talvez, primeiramente) à conscientização da forma que se está agindo.

Como já mencionado, o objetivo da instrutora era levar os alunos a perceberem que seus problemas com a escrita não se resumiam apenas a aspectos de gramática e vocabulário, uma vez que a língua (e a escrita) não se resume a esses aspectos. Para isso, ela precisava levá-los a perceber a natureza intrinsecamente social e cognitiva da língua. O caminho encontrado estava, nesse sentido, no questionamento de suas crenças. No entanto, antes de questioná-las era preciso torná-las explícitas e um dos caminhos para isso estava na investigação da origem dos sentimentos negativos apresentados pela

\footnotetext{
${ }^{38}$ Para essa afirmação, Barcelos (2007) se baseia em Freeman (1989).
} 
maioria das participantes no início do curso e que não havia ainda sido apresentado por MA. Levar os alunos a perceberem o porquê desses sentimentos, pedindo que comparassem suas experiências de escrita em língua materna com suas experiências de escrita em língua estrangeira, constituiu um caminho para mostrar-lhes a origem de suas dificuldades, que não estava, obviamente, na necessidade de conhecimento puramente linguístico, mas no conhecimento da relação entre língua, indivíduo e sociedade (do $A C P$ ), uma vez que a língua se constitui na relação dialética entre esses outros dois elementos. Nesse sentido, se MA não exteriorizasse seu problema com a escrita em inglês, como, finalmente, o fez, ao compará-la com sua língua materna, seria mais difícil encontrar um caminho para a mudança de suas concepções, considerando-se, como já mencionamos, que "para que as crenças mudem, a pessoa precisa perceber suas próprias crenças como não satisfatórias [...]” (BARCELOS, 2007, p. 119).

As respostas de MA às outras duas perguntas referentes às suas estratégias e principais dificuldades revelaram, igualmente, dois pontos positivos em relação a uma possibilidade de mudança. Primeiramente, MA demonstra perceber que a produção de um texto constitui um processo e que, como produto, é destinado a outros: “[...] escrevo um primeiro rascunho [...] até chegar à versão 'final' - final apenas porque tenho que torná-lo público". Outro aspecto importante diz respeito ao fato de MA não ter elencado como sua principal dificuldade nem gramática, nem vocabulário, como havia feito em seu primeiro conjunto de dados: “[...] minha dificuldade maior foi definir uma opinião". Repetir as mesmas perguntas sobre suas dificuldades em momentos diferentes no curso (antes e após uma atividade de produção escrita, por exemplo) constitui uma forma de questionar suas crenças, explicitá-las e desafiá-las. Mencionar diferentes tipos de dificuldade antes e após a realização de uma atividade revela uma 
contradição, instaura-se uma dúvida, desafia-se uma crença que, segundo explica Barcelos (2007), para ser substituída, precisa ser considerada insatisfatória.

Por outro lado, apesar de indicarem uma possibilidade de mudança, as respostas de MA em relação às suas estratégias e dificuldades, confirmam ainda a ausência de uma compreensão da natureza essencialmente social e cognitiva da língua e da compreensão do conceito de audiência, decorrente dessa natureza. Ao identificar a 'definição de uma opinião' como sua principal dificuldade em relação à escrita, MA avança em relação às dificuldades anteriormente mencionadas, relacionadas apenas à gramática e a vocabulário, no entanto, continua demonstrando uma concepção de produção textual ligada apenas ao contexto escolar, em que se propõe um tópico para ser desenvolvido e cujo produto é sempre e apenas destinado ao professor, representando, dessa forma, apenas um instrumento de avaliação. Nesse sentido, a expressão “[...] até chegar à versão 'final' - final apenas porque tenho que torná-lo público, porque acho que um texto nunca está acabado", utilizada por MA, revela que o público não se refere a uma audiência que, por sua vez, daria sentido e utilidade prática ao texto, mas público porque o professor o lerá e, talvez, seja exatamente essa ausência de propósito social do texto que produz que faz com que MA nunca esteja satisfeita com ele, tendo, por isso, a sensação de que nunca está acabado. De qualquer forma, como já refletimos, descobrir ou mencionar esse tipo de dificuldade (definição de uma opinião) revela um avanço no processo de mudança de suas concepções, uma vez que se percebe a consciência de que um texto é mais do que demonstração de conhecimento gramatical e lexical. Obviamente, um texto também não se resume à exposição de idéias fora de um contexto social específico, no entanto, a atividade de reflexão sobre o porquê desse tipo de dificuldade, constitui um caminho mais próximo da descoberta da verdadeira natureza de um texto autêntico, considerado uma 
manifestação concreta da relação dialética entre língua, indivíduo e sociedade, como o curso pretendeu demonstrar.

Em sua declaração referente ao primeiro dia de aula MA demonstra ter ficado surpresa com a heterogeneidade do grupo, reforçando seu interesse pelas questões teóricas e pedagógicas mencionadas anteriormente ("Ao final do primeiro encontro fiquei com a sensação do grande desafio que você terá para lidar com expectativas tão diferentes quanto as apresentadas pelos participantes do curso. [...] De minha parte, minha expectativa maior é em relação a material de leitura, conceitos, teorias"). No primeiro dia de aula, na primeira parte da aula, a instrutora pediu aos alunos que fizessem um círculo e que cada um se apresentasse e explicasse os motivos de seu interesse pelo curso. A exposição de diferentes objetivos por parte dos alunos foi um fator positivo no processo de promoção da mudança nas concepções de MA, que teve a oportunidade de refletir sobre as diferentes formas de utilização da escrita nos diferentes contextos sociais. De um modo geral, os alunos repetiram o que haviam respondido no Exame de Proficiência em relação aos seus motivos de interesse pelo curso.

Nesse ponto, analisaremos os dados produzidos por MA referentes 1) à aula de apresentação dos materiais de apoio, 2) à apresentação do filme "Freedom Writers" e 3) à leitura do texto de Foley (1989). Em relação aos materiais de apoio MA não fez nenhuma declaração. Em relação ao filme, MA fez o seguinte comentário:

I was already familiar with the movie Freedom Writers, which I watched during a course on the use of readers in EFL classes some time ago. As I love reading - and teaching, I loved the movie and felt a great admiration for the teacher's dedication to her students and the great results they achieved together. It seemed to me, however, that the price for such success was very high, which I found a little discouraging. Why should the teacher (I do not remember her name) get a second and third jobs to make money to buy books for her students, when there are so many taxes paid? Why should she become the kids' family, when they had their own mothers and fathers? Please, do not get me wrong: I am aware that both the families and 
the school system which should give support to the students did not correspond to their needs, but it should be considered that nowadays society is transferring more and more responsibilities to schools, and we teachers find ourselves in a very difficult position, being asked to solve all the problems in the world, which I find totally unfair.

O comentário de MA sobre o filme revela que o que mais lhe chamou a atenção foi o fato da professora ter dedicado todo seu tempo e seu dinheiro em prol de seus alunos ou, em outras palavras, ter realizado ações que foram além do seu papel de professora, que, na verdade, cabiam aos pais e à escola ou à sociedade. Sem dúvida, esta é uma crítica válida e um ponto importantíssimo para discussão, sobretudo, no contexto da nossa realidade e, portanto, uma preocupação compreensível considerando-se seu perfil de professora. Sem dúvida, o filme constitui uma rica fonte para a discussão de vários assuntos relativos à Educação e à sociedade de um modo geral. No entanto, o objetivo de sua apresentação pela instrutora era chamar a atenção para a forma como, primeiramente, a leitura e, depois, a escrita constituíram instrumentos para mudar a vida dos alunos que, a princípio, não via sentido em suas vidas, nessas práticas.

Em relação ao texto de Foley, MA escreveu o seguinte:

I was not familiar with the so-called 'five-paragraph essay' formula, but I did have writing classes with teachers who taught me some very useful 'rules of thumb', and I believe we can help students by giving them some guidelines, some parameters on how to outline their ideas. Going from the 'skeleton' to an elegant, creative text is a completely different challenge though, and that is why I decided to take this course. How can we help students (and, of course, ourselves, in the first place) take such 'quality leap'? The author's alternatives to the formula seem to 'ask for' other formulae, because students will surely need help to organize their ideas in chronological, spatial, causal, or any other possible order. It is a different approach, for sure, but, as the author himself (or herself?) mentions, more people have to think about it and share their ideas on how to help students write better. 
Em seu comentário sobre o texto da Foley, MA parece revelar uma crença (e, ao mesmo tempo, demonstra uma resistência em mudar essa crença) na necessidade de utilização de modelos como parâmetros para o ensino e a aprendizagem da escrita ("I believe we can help students by giving them some guidelines, some parameters on how to outline their ideas. [...] The author's alternatives to the formula seem to 'ask for' other formulae, because students will surely need help to organize their ideas in chronological, spatial, causal, or any other possible order"). Por outro lado, deixa claro sua dúvida sobre qual seria, afinal, o tipo de conhecimento necessário (ou a fórmula mais adequada) para um aprendizado efetivo da escrita (“Going from the 'skeleton' to an elegant, creative text is a completely different challenge though, and that is why I decided to take this course. [...] as the author himself (or herself?) mentions, more people have to think about it and share their ideas on how to help students write better"). Novamente, a dúvida e a incerteza aparecem nos dados de MA e, como já discutimos, constituem elementos fundamentais para a mudança de crenças. O objetivo da instrutora ao propor a leitura de Foley (1989) era exatamente o de questionar suas crenças em relação ao uso de modelos como instrumentos de aprendizagem da escrita e produção de textos. Até esse ponto no curso, a instrutora não havia mencionado o conceito de gênero textual, nem havia deixado claro de que forma pretendia ensiná-los a escrever melhor. O objetivo era, na verdade, que eles mesmos percebessem o que lhes era necessário que, como já explicamos, consistia no conhecimento do $A C P$ (que, por sua vez, lhes guiaria na construção de textos autênticos baseados em necessidades práticas reais e dirigidos a audiências reais e específicas) e não na memorização de regras ou na análise superficial das características de tipos de textos, como demonstravam acreditar. Para isso, a instrutora estava questionando suas crenças e, ao invés de lhes dar a resposta, pretendia dar-lhes as condições para 
descobrirem por si mesmos, sendo coerente, dessa forma, com a abordagem utilizada no curso que previa o desenvolvimento nos alunos das capacidades de auto-controle e autoavaliação do seu processo de aprendizagem.

Após a aula em que foram discutidos o filme e o texto da Foley, MA fez as seguintes declarações em seu diário:

As discussões realizadas na aula de hoje foram muito importantes, principalmente para aqueles entre nós que vão ensinar produção textual em português ou em LEM - seja na educação regular ou em cursos de idiomas. Dar sentido às atividades propostas em sala é, sem dúvida, uma ação importante para motivar os alunos.

Por outro lado, refletir sobre o que não dá certo parece ter aumentado a expectativa do grupo para encontrar 'caminhos', 'receitas' que possam dar certo. $O$ convite para abrir mão dos modelos e buscar alternativas nos tira da zona de conforto, e incomoda. Mas penso que é assim que podemos aprender, podemos crescer...

O primeiro parágrafo da declaração de MA revela, pela primeira vez, uma forma aparentemente nova de se conceber escrita, como uma atividade significativa (relacionada às necessidades práticas dos indivíduos) e não como simples instrumento de avaliação (como até então ocorria) ou, talvez apenas (mas não menos importante), uma conscientização sobre isso ("Dar sentido às atividades propostas em sala é, sem dúvida, uma ação importante para motivar os alunos"). O segundo parágrafo, por sua vez, confirma a eficácia das estratégias utilizadas pela instrutora para promover a mudança de crenças nos alunos por meio da sua explicitação, reflexão e questionamento, gerando sentimentos de dúvida e incerteza (“O convite para abrir mão dos modelos e buscar alternativas nos tira da zona de conforto, e incomoda. Mas penso que é assim que podemos aprender, podemos crescer..."). No entanto, segundo 
Simão et al. (2005, p.175), a mudança constitui um processo "complexo, interativo e multidimensional" e, conforme Pajares (1992, p.321), antes de serem assimiladas, as novas crenças "passam por testes e, se não forem eficientes, correm o risco de serem descartadas”. Nesse sentido, ainda que não possamos afirmar que já está ocorrendo uma mudança em suas crenças, podemos, pelo menos, ver indícios de um movimento nessa direção.

A partir desse momento, analisaremos os últimos dados produzidos por MA e que constituem suas respostas às perguntas elaboradas pela instrutora a partir das discussões realizadas em aula sobre a língua e a escrita de um modo geral. Reproduzimos abaixo tanto as perguntas como as respostas para facilitar a leitura e a compreensão da análise dos dados:

1. What's the importance of a summary?

Vejo o exercício de fazer um resumo como uma oportunidade de organizar e registrar as ideias principais de um texto lido. O produto final serve então para futuras consultas/referências sobre determinado assunto, razão pela qual penso que o gênero foi criado.

2. Como uma criança aprende a falar? (É possível uma criança aprender duas ou mais línguas ao mesmo tempo? Por quê?)

Penso que a criança aprende sua(s) língua(s) materna(s) a partir da necessidade inerente ao ser humano de comunicação, apoiando-se nas estruturas cognitivas que também são inerentes ao ser humano, e que são acionadas na interação social. Acredito que seja possível para uma criança aprender a falar várias línguas ao mesmo tempo, já que ela tem a capacidade para lidar com a informação recebida, processando-a $\boldsymbol{e}$ utilizando-a para comunicar-se em diferentes contextos. 
3. Qual a principal diferença entre a forma como uma criança aprende sua língua materna e como um adulto aprende uma língua estrangeira?

Pelo que observei em minha experiência como aluna e professora de LEM, a forma como um adulto se aproxima do processo de aprendizagem é completamente diferente. Quando adultos o processo é muito mais racional (pensamos sobre o processo, comparamos a LEM como nossa língua materna, etc), e, paradoxalmente, é também muito mais emocional (monitoramos nosso progresso de forma mais exigente; ficamos frustrados mais facilmente quando não conseguimos transmitir a ideia que temos em LE, etc).

4. O que a aprendizagem de uma ou mais línguas na infância promove na vida de uma criança? (Que impacto o aprendizado da língua tem na vida da criança? Pense no caso das meninas-lobo.)

Aprender uma língua é aprender a pensar, a ativar as funções cerebrais superiores, então é vital para o desenvolvimento total do indivíduo. Nem precisamos ir a extremos como no caso das meninas-lobo. Crianças surdas também podem ter problemas cognitivos, pessoais e sociais sérios se não tiverem a oportunidade de desenvolver suas capacidades de comunicação dentro de suas possibilidades físicas, um direito que só recentemente foi alcançado no Brasil.

5. O que é a escrita? É possível aprender a escrever antes de falar? Como você explica a eficácia (a existência) dos cursos de inglês instrumental, por exemplo, que ensinam apenas leitura.

No caso de surdos, por exemplo, isso é bastante comum, mas o português escrito é para muitos deles uma segunda língua, que aprendem de forma instrumental, como em cursos de língua estrangeira preparatórios para provas e concursos. Penso que isso quer dizer que é possível aprender a escrever em uma língua sem aprender a falá-la, mas não é possível aprender a escrever em uma língua (seja materna, segunda, ou estrangeira), sem se ter aprendido a organizar o pensamento, sem se ter aprendido a expressar opiniões, sensações, sentimentos, etc.

6. Qual a principal vantagem de se estar no país em que sua segunda língua é falada? 
O contato mais freqüente com a língua em situações reais e o ganho em termos culturais.

7. Como você define um bom falante?

Como discutimos em sala, o bom falante é aquele que consegue comunicar-se com audiências diversas, sobre temas diversos, utilizando gêneros diversos, sabendo fazer as escolhas mais apropriadas para cada interação.

8. E um bom escritor?

A mesma coisa, só que através da língua escrita.

9. Por que certos tipos de textos são mais fáceis de escrever do que outros?

Porque o escritor tem mais familiaridade com o tema ou como o tipo textual em questão.

10. Por que é importante entendermos a relação língua-contexto? De que forma isso nos fará bons escritores?

A comunicação é inerentemente social, então se realiza dentro de um determinado contexto, que define a e que é definido pela linguagem. Penso que somente poderemos ser falantes ou escritores bons se tivermos consciência desta relação.

11. O que uma abordagem para o ensino da escrita baseada em modelos pode acarretar? 
Eu faria a ressalva para 'uma abordagem baseada apenas em modelos', pois penso que precisamos passar por modelos em um momento inicial de qualquer processo de aprendizagem. Mas o desafio - tanto para o professor quanto para o aluno - é reconhecer a hora de superar a fase de imitação e descobrir estratégias que criem as bases para a fase da criatividade.

12. Na sua opinião, o que é gênero? Como surge um gênero?

\begin{abstract}
Ainda estou em processo de construção deste conceito, mas penso que os diferentes gêneros são uma construção social que visa organizar $\boldsymbol{e}$ estabilizar as atividades comunicativas humanas, com foco na intenção comunicativa. Desta forma, teríamos, por exemplo, o gênero narrativo, o expositivo, $o$ argumentativo, etc. Tais intenções comunicativas se 'concretizariam' através de diferentes tipos textuais, como por exemplo, carta, poema, e-mail, abstract, etc.
\end{abstract}

Todas essas respostas, que se referem a questões interligadas, foram enviadas de uma só vez e baseadas nas últimas discussões que haviam sido realizadas em aula. De um modo geral, podemos dizer que algumas expressões utilizadas por MA parecem indicar uma mudança em sua forma de compreender língua e escrita, no entanto, outras, revelam que essa mudança não está completamente concretizada. Por exemplo, em sua resposta à pergunta sobre o resumo, que visava reforçar a idéia discutida em aula sobre a relação entre escrita e necessidade pessoal/cognitiva e gênero e propósito social, MA demonstrou ter refletido e compreendido essa relação: "[...] organizar e registrar as ideias principais de um texto lido. O produto final serve então para futuras consultas/referências sobre determinado assunto [...]". Nessa e em outras respostas, MA demonstra perceber a relação entre escrita, indivíduo e sociedade: “[...] a criança aprende sua(s) língua(s) materna(s) a partir da necessidade inerente ao ser humano de comunicação, apoiando-se nas estruturas cognitivas que também são inerentes ao ser humano, e que são acionadas na interação social. [...] utilizando-a para 
comunicar-se em diferentes contextos"; "A comunicação é inerentemente social, então se realiza dentro de um determinado contexto, que define a e que é definido pela linguagem. Penso que somente poderemos ser falantes ou escritores bons se tivermos consciência desta relação”. No entanto, em outras, revela que essa compreensão ainda não se concretizou efetivamente: “[...] penso que precisamos passar por modelos em um momento inicial $[\ldots]$ o desafio $[\ldots]$ é $[\ldots]$ descobrir estratégias que criem as bases para a fase da criatividade"; "[...] Ainda estou em processo de construção deste conceito $[\ldots] ”$

De um modo geral, podemos concluir que os dados produzidos por MA ao longo do curso indicam o início de um processo de mudança de suas concepções. Como já mencionamos, a mudança de crenças constitui um processo complexo que leva tempo e envolve a modificação de todo um sistema, uma vez que umas estão conectadas às outras (WOODS, 1996). Os estudos sobre crenças também chamam a atenção para o fato de que crenças relacionadas às experiências passadas (no caso de $\mathbf{M A}$, limitadas ao contexto escolar) e crenças de professores com muitos anos de experiência (BARCELOS, 2007), como é o seu caso, é muito mais difícil de ocorrem. Por outro lado, considerando-se o curto espaço de tempo em que o curso foi realizado ( 27 horas), MA revelou sinais de mudança na forma de conscientização de suas crenças sobre suas dificuldades e necessidades de aprendizagem e sobre aspectos da língua e da escrita em geral, propiciados, por sua vez, pelas oportunidades que teve de refletir sobre a língua e a escrita a partir de 1) suas próprias experiências (e dos outros alunos), 2) de textos teóricos e 3) amostras de gêneros, passando por momentos de dúvidas e incertezas, fundamentais para que as mudanças ocorram. 


\subsubsection{Análise do diário de DI}

Os dados produzidos por DI no início do curso revelaram, como vimos, concepções tradicionais de língua e escrita, assim como os dados das demais participantes. Apesar de seu interesse em utilizar a escrita em situações autênticas no contexto acadêmico ("it's necessary for my academic and professional carreer"), compatível, portanto, com seu perfil ${ }^{39}$, DI possui um histórico de longa experiência com a escrita em contexto escolar e, em decorrência disso, acredita, como vimos, que suas dificuldades são provenientes da falta de conhecimento (ou treinamento) de aspectos da língua ligados à gramática e a vocabulário (“Penso q vocabulário e gramática...”). Além disso, expressou sentimentos negativos em relação à escrita ("Quero me sentir segura para escrever como me sinto para falar") que, como discutimos, por um lado, refletem a crença na necessidade (e, ao mesmo tempo e paradoxalmente, na impossibilidade) de se dominar completamente as estruturas e o vocabulário da línguaalvo e, por outro lado, representam a ineficácia das abordagens tradicionais de ensino (por meio das quais, provavelmente, foi ensinada) para desenvolverem eficazmente essa habilidade nos alunos.

Reproduzimos abaixo as respostas de DI às primeiras perguntas feitas em seu diário (as perguntas foram também reproduzidas para facilitar a leitura e a análise):

1) Como você se sentiu quando a instrutora disse que após o intervalo vocês fariam uma atividade de produção textual em forma de teste? Como você se sente quando tem que escrever em inglês? E na sua língua materna? Qual a diferença?

No sábado senti medo. Tenho um medo da-na-do de errar. Maior ainda de passar vergonha!!! rs... Em geral, apenas escrever em inglês não me dá medo, penso neste momento que tenho preguiça. Acho q acabei de encontrar o " $x$ " da questão...rs. Me parece mto igual a começar o inglês instrumental... ter q procurar palavras é cansativo.. Mas td bem, agora estou me propondo, certo? Logo, vou fazê-lo! Agora...escrever na língua

\footnotetext{
${ }^{39}$ DI é doutora na área de Nutrição Humana Aplicada, editora de uma revista e professora universitária.
} 
materna eu ADOOORO! É q, na verdade, gosto de me expressar!! Por escrito $t b !$ rs....

2) Como foi durante o processo de escrita do texto? O que você fez primeiro? Organizei as idéias; Você usou a folha de rascunhos? Sim, Para quê, exatamente: para anotar suas idéias ou para escrever o texto e depois corrigi-lo? Para corrigir, principalmente. O pior é q desisti...rs...não consegui continuar o que havia feito primeiro, havia mta explicação redundante e, por fim, percebi $q$ não argumentei como era solicitado. Mas só me toquei disso em casa...acho q já era quase noite..rs...O q Tb me ajudou a perceber q o micro piorou demais a minha letra!!! Noooosssaaa! Preciso comprar um caderno de caligrafia!!

3) Quais foram as suas principais dificuldades na hora de escrever (organizar as idéias Não definir uma opinião em relação ao assunto do texto sim, pois unca pensei em me explicar naquele assunto falta de vocabulário também, falta de conhecimento gramatical para desenvolver as idéias etc)? Puxa, fiquei tão perdida por não saber argumentar que nem percebi quais foram as dificuldades gramaticais, até $p q$ provavelmente ainda não identifiquei os erros... preciso retomar...talvez antes deste Sábado mesmo, se eu tiver tempo....

Esta semana está especialmente corrida...

A resposta de DI à primeira pergunta confirma seu desejo, apresentado na primeira etapa da análise, de se sentir melhor e mais segura ao escrever em inglês ("feel well to write"; "Liberdade na escrita. Quero me sentir segura para escrever como me sinto para falar"). A instrutora esperava que, por meio da reflexão a respeito dos problemas que estavam enfrentando em relação à escrita, as alunas fossem levadas a investigar suas origens e perceber, enfim, que suas causas não estavam relacionadas à falta de conhecimento ou treinamento de aspectos da língua ligados à gramática e/ou a vocabulário, como demonstravam acreditar. O objetivo da instrutora era mostrar-lhes que a origem de suas dificuldades e dos sentimentos negativos, era, na verdade, resultado da ineficácia das abordagens tradicionais, por meio das quais, provavelmente, haviam sido ensinadas, e da sua própria crença nesse tipo de ensino que, por sua vez, as 
impedia de mudar essa realidade. Nesse sentido, a reflexão realizada por DI sobre seus sentimentos em sua resposta à primeira pergunta, estabeleceu uma zona de desenvolvimento potencial para a mudança de suas crenças, uma vez que propiciou a reflexão e instaurou a dúvida, elementos fundamentais para a promoção da mudança, como vimos anteriormente, segundo a literatura sobre crenças $(([\ldots]$ senti medo. Tenho um medo da-na-do de errar. Maior ainda de passar vergonha!!!,[...] escrever em inglês não me dá medo, penso neste momento que tenho preguiça. Acho q acabei de encontrar o " $x$ ” da questão...rs. [...] ter q procurar palavras é cansativo.. Mas $t d$ bem, agora estou me propondo, certo? Logo, vou fazê-lo! Agora...escrever na língua materna eu ADOOORO! É q, na verdade, gosto de me expressar!! Por escrito tb!).

Por outro lado, apesar da reflexão e das incertezas instauradas, as expressões utilizadas por DI ainda revelam suas concepções tradicionais de língua e escrita. Ao concluir que o que sente é, na verdade, "preguiça" pelo fato de que "procurar palavras é cansativo", DI revela uma concepção de escrita como sinônimo da atividade mecânica (e, por isso, cansativa) de somar palavras. E ao revelar que sente "medo [...] de errar. Maior ainda de passar vergonha!!! [...]”, demonstra, por sua vez, uma visão de texto bem escrito como sinônimo de um texto sem erros e objeto de avaliação e não instrumento de atividade prática ou cognitiva no mundo.

As expressões utilizadas por DI para responder à segunda pergunta reforçam, por sua vez, a visão de texto como objeto de avaliação, sendo dirigido especificamente ao professor ([...] percebi q não argumentei como era solicitado. Mas só me toquei disso em casa...acho q já era quase noite..rs...O q $\mathbf{T b}$ me ajudou a perceber q o micro piorou demais a minha letra!!! Noooosssaaa! Preciso comprar um caderno de caligrafia!!) Obviamente, essa era uma atividade de escrita avaliativa e que teria como "audiência" apenas o professor. No entanto, suas preocupações com a avaliação de um 
modo geral e a ausência de expressões que pudessem revelar a expectativa por outro tipo de atividade revelam uma concepção generalizadamente tradicional e não apenas em relação a essa atividade especificamente.

Em sua resposta à terceira pergunta, referente às suas principais dificuldades, DI menciona um problema novo em relação à escrita ("não saber argumentar"). No entanto, demonstra preocupação com o fato de não ter prestado atenção nos erros gramaticais ("Puxa, fiquei tão perdida por não saber argumentar que nem percebi quais foram as dificuldades gramaticais, até pq provavelmente ainda não identifiquei os erros... preciso retomar..."). Esse comportamento de DI, por um lado, confirma suas concepções tradicionais de língua e escrita (ao demonstrar demasiada preocupação com seus possíveis erros gramaticais), e, por outro lado, revelam a presença de um elemento desestabilizador em suas crenças sobre suas dificuldades. Se a resposta para o problema da falta de conhecimentos de gramática e vocabulário corresponderia à aquisição de mais conhecimento ou treinamento desses aspectos línguísticos, a resposta para o novo problema correspondia ao conteúdo-objeto do curso: o ACP. Nesse sentido, podemos dizer que essa primeira atividade de produção textual e as questões propostas pela instrutora foram propiciadoras de reflexão e suscitação de dúvidas capazes, por sua vez, de conduzir à mudança.

Após a apresentação do filme, antes de comentar sobre ele ${ }^{40}$, MA fez a seguinte declaração em seu diário:

Meu querido diário:

\footnotetext{
${ }^{40}$ Em seus diários, a instrutora apenas fez a seguinte pergunta: O que você achou do filme?
} 
Escrever o que estou sentindo e pensando é de uma oportunidade ímpar! Embora tenha um blog [...], tenho certeza q nenhum dos meus leitores/as são tão atentos qto a minha professora q vai ler estas linhas!!! . rs... Fator fundamental para eu me sentir estimulada a fazer melhor ainda!! rs...

Essa declaração de DI revela como a escrita, para ser prazerosa, precisa fazer sentido, ou seja, estar relacionada a atividades práticas ou cognitivas reais e autênticas e não apenas constituir instrumento de avaliação (como ocorreu, por exemplo, com a primeira atividade de produção escrita de que participaram). A escrita nos diários (que poderia ser feita tanto em inglês como em língua materna) não constituiu uma atividade para ser corrigida; ela tinha a função de expressar a compreensão, as dúvidas e as impressões em geral dos alunos em relação às aulas, representando, dessa forma, uma experiência significativa com a escrita.

Sobre o filme, DI fez o seguinte comentário ${ }^{41}$ :

Nossa! Bárbaro! Parece mentira mas me sinto exatamente como ela e dou curso de formação para professores da rede pública da capital de São Paulo! Acho q por isso mesmo não consegui cotrolar minha tristeza. $Q$ me dói inclusive agora, por lembrar cenas do filme. Ao mesmo tempo ele me ajuda a confirmar minha crença qto à importância dos professores na vida dos tantos alunos $q$ existem pelo mundo!!! Amo o q faço e percebo nitidamente $q$ minha professora [...] Tb! Nossa! Gde estímulo esta mocinha!!! Pra todos nós!! Como ela acredito que é fundamental "marcar" emocionalmente o processo de aprendizagem e compreendo o valor de investir uma aula para assistir o filme que, honestamente, eu não assistiria em qq outra situação pelo q disse: conheço akela realidade inteira...ipsis ilíteris.... cada personagem...inclusive o "oco" par $q$ a protagonista escolheu. Então sempre penso q fimes nesta linha confirmam minhas crenças mas "não acrescentam", pois sou professora há 23 anos e, sem falsa modéstia, tenho uma linha diferenciada de trabalho. Por isso insisto $q$ as estratégias, sucessos e insucessos q o filme apresenta já conheço. $\boldsymbol{A}$ novidade pra mim foi encontrar uma professora $q$ está se propondo a “ouvir”, a sensibilizar, à conquistar alunos!! Uau!! Isso sim é o máximo [...] Não perco sua aula por nada!! Mesmo "atolada” como estou de trabalho pessoal...rs...Vc é fantástica e tem me surpreendido pois penso

\footnotetext{
${ }^{41}$ As partes suprimidas citam nomes de pessoas e instituições e, por isso, foram preservados.
} 
exatamente isso: a aula é para reflexão. Em casa é para ler a treoria e os exercícios são para fixação. Bárbaro!! E conhecer autores q escrevem sobre isso, então é o máximo! Pois faço por puro "feeling" profissional..rs...intuição e ensaio e erro... rs..Estou amando tudo isso! Mto obrigada!

Em seu comentário sobre o filme, DI revela o quanto se identificou com ele ("Parece mentira [,] mas me sinto exatamente como ela [a professora-protagonista da história]") e explica os motivos pelos quais tanto se emocionou: DI é formadora de professores de escola pública e, segundo ela, conhece bem a realidade e "as estratégias, sucessos e insucessos q o filme apresenta". Nesse sentido, como ela mesma declara: "fi[l]mes nesta linha confirmam minhas crenças mas "não acrescentam". O que DI considera novidade é o fato de estar em um curso em que, assim como ela e a protagonista do filme, a professora também se preocupa em ouvir seus alunos, em promover reflexões e discussões em aula sobre o tema proposto ("A novidade pra mim foi encontrar uma professora q está se propondo a “ouvir”, a sensibilizar, à conquistar alunos!! [...] penso exatamente isso: a aula é para reflexão. Em casa é para ler a $t[\mathrm{r}]$ eoria e os exercícios são para fixação. Bárbaro!!’”). A forma entusiástica como DI se expressa nessa resposta em relação ao filme e as expressões que utiliza revelam um momento de conscientização a respeito de suas próprias crenças sobre educação de um modo geral e sobre os processos de ensino e aprendizagem (“[...] ele [o filme] me ajuda a confirmar minha crença qto à importância dos professores na vida dos tantos alunos q existem pelo mundo!!! [...] Como ela [a instrutora do curso] acredito que é fundamental "marcar" emocionalmente o processo de aprendizagem e compreendo o valor de investir uma aula para assistir o filme [...]"). No entanto, suas crenças sobre o ensino e a aprendizagem da escrita, especificamente, parecem não ter 
sido muito influenciadas, como é possível observar em sua resposta referente a leitura de Foley $(1989)^{42}$ :

Outra grande surpresa!! .rs..

Nunca ouvira esta proposta de 5 parágrafos...Certamente pq não estudo isso e por ter vindo da escola pública na infância e adolescência...Agradeço a Deus a profa. Clélia na minha vida, da $5^{a}$ à $8^{a}$ série, pois ela nos infernizou com tempos verbais...e valeu a pena!!

Foi enriquecedor e inspirador, pra mim.

A partir desta leitura "me conscientizei" $q$ deverei proceder como no instrumental: step by step... Puxa! Pensei q isso já havia passado...rs...Tava com uma preguiça danada de "retomar"... de ir pro dicionário...Mas "retomei". Me senti mais competente depois desta leitura e, particularmente, adorei a suscinta explicação dos padrões de organização dos escritores. Mas confirmei outra crença: a viagem do escrever! Construtivo. Subi mais um degrau. Me sinto mais confiante a cada leitura, a cada aula. Obrigada!

Mesmo considerando a leitura inspiradora ("[...] Foi enriquecedor e inspirador, pra mim [...]”) e motivadora (“[...] Me senti mais competente depois desta leitura [...] Subi mais um degrau. Me sinto mais confiante a cada leitura [...]"), DI demonstra acreditar que grande parte do trabalho da escrita está ligado à tarefa de procurar palavras no dicionário (“[...] Tava com uma preguiça danada de "retomar”... de ir pro dicionário...Mas "retomei" [...]"). E mesmo que DI esteja se referindo ao trabalho de procurar palavras no dicionário de um modo metafórico, sua metáfora representa, de qualquer modo, uma visão tradicional de língua e escrita.

Vejamos, agora, as respostas de DI às questões discutidas em aula sobre a língua e a escrita de um modo geral:

\footnotetext{
${ }^{42}$ Em seus diários, a instrutora fez a seguinte pergunta: O que achou do texto da Foley?
} 
Como uma criança aprende a falar? Por imitação, mas em aula foi dito $q$, primeiro, o bebê precisa abstrair o que seja uma bola para falar dela mesmo qdo não está à sua frente.

(É possível uma criança aprender duas ou mais línguas ao mesmo tempo? Sim, Por quê? Penso eu q, a partir do momento q ela aprendeu a abstrair fazê-lo em diferentes línguas pode significar o mesmo esforço.

Qual a principal diferença entre a forma como uma criança aprende sua língua materna e como um adulto aprende uma língua estrangeira? Penso $\boldsymbol{q}$ passa a ser uma abstração da abstração pois. Ao menos pra mim, preciso ver a grafia da palavra ...não apenas o som...

O que a aprendizagem de uma ou mais línguas na infância promove na vida de uma criança? (Que impacto o aprendizado da língua tem na vida da criança? Pense no caso das meninas-lobo.) Sobrevivência e capacidade de expressar-se. Algo $q$ acho fantástico até pq aumenta a possibilidade de diferentes contatos!

O que é a escrita? Falamos em aula que a ESCRITA É UM PROCESSO CRIATIVO QUE DEPENDE DA CAPACIDADE DE ABSTRAIR (PENSAR, REFLETIR E PLANEJAR), PQ ELA É O SÍMBOLO DO SÍMBOLO É possível aprender a escrever antes de falar? Sim...pela visão, ao invés da audição..., Como você explica a eficácia (a existência) dos cursos de inglês instrumental, por exemplo, que ensinam apenas leitura. Maravilhoso! Salvou meu mestrado!!! rs...pesno q são processos distintos e q, qdo associados, sobrecarregam o sistema de aprendizagem (no adulto) $e$, por isso, em cjt, são + lentos do q apenas o instrumental sozinho....

Qual a principal vantagem de se estar no país em que sua segunda língua é falada? Todos os sentidos estão no msmo canal de processamento. Até o pensamento/raciocínio se mantêm na língua estrangeira...

Como você define um bom falante? Falamos em aula que é alguém q sabe se expressar em diferentes contextos, com palavras corretas, pessoas corretas na hora certa!

E um bom escritor? Tb falamos em aula que é alguém q sabe se se expressar em diferentes contexto 
Por que certos tipos de textos são mais fáceis de escrever do que outros? $P q$ envolvem raciocínio linear ou positivista...aqueles $q$ explicam quase todos os fatores relacionados a uma questão são mais difíceis...tipo aqueles que são eminentemente persuasivos...

Por que é importante entendermos a relação língua-contexto? De que forma isso nos fará bons escritores? se expressar em diferentes contextos

O que uma abordagem para o ensino da escrita baseada em modelos pode acarretar? Pode cercear o escritor e desinteressar o leitor.

Na sua opinião, o que é gênero? Como surge um gênero? rs...até este dia não estava tão claro. $O$ q sei mais é pq estou respondendo dia 4.11 por isso nem vou citar...

As respostas de DI às questões sobre a língua e a escrita mostram que houve reflexão e compreensão de muitos conceitos apresentados e discutidos em aula. No entanto, sua compreensão da importância de se conhecer a relação língua-contexto (língua, indivíduo e sociedade) para o desenvolvimento da habilidade da escrita ou para a produção de textos não parece estar clara e sua resposta sobre gênero textual também não nos permite afirmar se ocorre ou não compreensão desse conceito. O objetivo da instrutora era levar os alunos a compreenderem o conceito de gênero como uma manifestação concreta de um princípio teórico, o princípio comunicativo básico $(A C P)$, representado, por sua vez, pela relação dialética entre língua, indivíduo e sociedade. Nesse sentido, afirmar que o bom escritor é aquele que sabe escrever bem em diferentes contextos e para diferentes audiências não significa, necessariamente, que se entende o conceito de gênero como o resultado da (e não o molde para) relação entre aspectos linguísticos, cognitivos e sócio-culturais envolvidos na prática social discursiva. De 
qualquer forma, DI, assim como as demais alunas, tiveram a oportunidade de ouvir sobre, refletir e discutir aspectos relacionados à língua e à escrita e, dessa forma, desestabilizar certas crenças, confirmar outras e, principalmente, iniciar um processo em direção a uma mudança.

Nesse ponto, analisaremos o último diário de DI escrito após as aulas em que a instrutora promoveu uma reflexão sobre os aspectos sociais e cognitivos da língua e da escrita:

$\begin{array}{lll}\mathrm{Meu} & \text { querido diário }\end{array}$

1. Resumo do $q$ vimos em aula: "a escrita é um processo criativo que depende da capacidade de abstração (pensar, refletir e planejar), pois ela é o símbolo do símbolo* ; "nascemos com capacidade para desenvolvimento das funções superiores que são justamente provocadas/permitidas/viabilizadas/potencializadas pela linguagem (meninas lobo); a cultura é fundamental para aquisição da linguagem; "somente é Possível escrever apos aprendizagem da abstração da fala (q precisa ser natural); "ex. Imaginar o leitor é uma abstração q "piora"em acordo com o aumento da distancia pois maior deverá ser o grau de abstração e assim, + difícil será a escrita; "se não houver necessidade de escrever não haverá sentido; "a escrita não é uma transcrição da fala"*; o bom falante sabe se expressar em diferentes cntextos, o escritor também; sempre deve haver uma necessidade para estimular, como o problema de uma pesquisa; é preciso haver um PROPÓSITO; Para adaptar este conhecimento em acordo com meu propósito preciso estudar: a lógica da relação língua-contexto, sensibilizar quem eu quero convencer, compreender o que eu não sei sobre escrita, investigar a relação língua-contexto pois o vocabulário muda em acordo com o texto; devo ler para aprender como aquele autor chegou no propósito dele (persuadir), para eu ter a liberdade e o conhecimento suficientes e necessários

para

escolher,

2. Qto a como percebo meu aprendizado: Cintia querida!!! A cada aula fico encantada com este/seu conteúdo!! $Q$ delícia conhecer "este lado" da moeda! Terminei a graduação em 1987, na [...](particular) e no curso de Ed. Física q foi (e em mtas ainda é), eminentemente prático. Não tivemos TCC. Fiz mais umas 2 especializações $q$ tb nada exigiram... fui convidada à entrar no mestrado, em 1995 e quase chorei sangue para escrever a dissertação...( sou exagerada, sim? rs...). Daí q tomei gosto pela coisa e, por 
instinto puro sempre me preocupei com o leitor e em como apresentar-lhe um raciocinio $q$ "o ajudasse a comprar minha idéia". Tem dado super certo mas, agora no seu curso, compreendi uma série de coisas!!! Coloquei 2 asteriscos $p q$ nas frases acima para comentá-las aqui: - "a escrita não é uma transcrição da fala - nossa! Q alivio saber disso! Em geral as pessoas elogiam mto minhas palestras e cobram um livro. Não tenho vontade de fazer isso: uma transcrição minha fala e aqui aprendi $q$ "estou no caminho certo"! Bárbaro! Obrigada! - "a escrita é um processo criativo que depende da capacidade de abstração (pensar, refletir e planejar), pois ela é o símbolo do símbolo* Nossa! Esta informação foi um gde tesouro q ganhei por vir aqui/lá, no seu curso!!!! Pois sou professora de metodologia da pesquisa na pós-graduação e pedi demissão, aos poucos em todas as universidades q lecionava pq eles estão tão comerciais $q$ os alunos se sentem medíocres qdo, na verdade, a Universidade oferece uma mentira! $O$ curso não lhes dá condição para aprendizagem da escrita!!! Owwww vc está me ajudando tanto a entender $q$ estou no caminho certo!!! E embasada!!! Ai q maravilhoso!! Me sinto mais feliz à cada aula!!! Obrigada!

3. Qto aos meus problemas com a escrita em inglês: bom, aos poucos estou percebendo q tenho mais problemas do q pensava...rs...Bem é q antes eu achava q era "só" um problema de gramática...rs... Tenho aprendido q não... Mas, por outro lado, estou me percebendo mais segura! Mais confiante! To adorando td isso! Sim, pois embora não estivesse claro que me sentia insegura, tinha um baita medo de "por minha cara a tapa"! Bom, basta perceber q defenti o doutorado em abril de 2005 e não publiquei a tese até agora... a partir dela já realizei inúmeros cursos, 2 simpósios e 1 congresso...rs...orientei inúmeras pesquisas dos professores mas, eu...o meu texto...nada....rs...E, mesmo não fazendo as tarefas oq estava sobrecarregada e mto agradecida por vc não ter me "sugerido"sair por isso...rs... tenho percebido (e sentido), minha melhora a cada semana, a cada encontro! A teoria estou colocando em prática e está fantástico! Obrigada! Bem, então, meu interesse específico é escrever (primeiro), o artigo da tese!

Neste último depoimento, DI faz declarações que mostram o quanto as reflexões e as discussões em aula contribuíram 1) para que muitas de suas crenças se tornassem explícitas e fossem confirmadas, ajudando-a em suas decisões pessoais (“[...] vc está me ajudando tanto a entender q estou no caminho certo!!! E embasada!!! [...]”) e 2) na forma como passou a enxergar a atividade da escrita (“[...] Esta informação foi um gde tesouro q ganhei por vir aqui/lá, no seu curso!!!!.[...] os alunos se sentem mediocres 
qdo, na verdade, a Universidade oferece uma mentira! O curso não lhes dá condição para aprendizagem da escrita!!! [...])".

Nesse sentido, podemos concluir que houve 1) um movimento em direção à mudança, sobretudo, de seus sentimentos em relação à escrita(“[...] estou me percebendo mais segura! Mais confiante! To adorando td isso! Sim, pois embora não estivesse claro que me sentia insegura, tinha um baita medo de "por minha cara a tapa"![...]"), e 2) uma conscientização sobre o seu próprio processo de aprendizagem e desenvolvimento ("Qto a como percebo meu aprendizado [...] aos poucos estou percebendo q tenho mais problemas do q pensava...rs...Bem é q antes eu achava q era “só” um problema de gramática...rs... Tenho aprendido q não... [...] tenho percebido (e sentido), minha melhora a cada semana, a cada encontro! [...]”). No entanto, não podemos afirmar que houve mudança propriamente de suas concepções de língua e escrita, uma vez que para que ela se concretizasse seriam necessários mais tempo de intervenção e mais dados que a comprovassem. A importância e o valor que tiveram as reflexões e as discussões realizadas em aula para DI são, no entanto, visíveis e podem ser comprovadas pela emoção e o entusiasmo com que faz suas declarações ("[...] Ai q maravilhoso!! Me sinto mais feliz à cada aula!!! Obrigada! [...]”).

\subsubsection{Análise do diário de NA}

Como vimos na primeira etapa da análise, os dados produzidos por NA no início do curso revelaram concepções tradicionais de língua e escrita, como também ocorreu com as demais participantes. NA apresentou objetivos caracterizados como 'profissional e/ou acadêmico' (“desejo entrar no mercado de tradução [...]”), mas também mencionou objetivos incluídos nas categorias 'emocional' ("achieve more confidence") 
e "escolar' ("[...] improve writing skills"; "need a lot of training"; "achieve more [...] vocabulary"). E, apesar de ser graduada em Letras e Mestre na área de Tradução, apontou aspectos de gramática, vocabulário e fluência como suas principais dificuldades em relação à escrita (“[...] questão de gramática”; "falta de treino com o vocabulário"; “[...] tenho dificuldade com a espontaneidade em escrever"). Após a realização da primeira atividade de produção textual, NA respondeu da seguinte forma às perguntas feitas pela instrutora em seu diário:

1) Como você se sentiu quando a instrutora disse que após o intervalo vocês fariam uma atividade de produção textual em forma de teste? Como você se sente quando tem que escrever em inglês? E na sua língua materna? Qual a diferença?

- Achei que o teste fazia parte do objetivo do curso, uma espécie de tarefa prática, já que é disso que o curso trata. Escrever em inglês me causa, num primeiro momento, um certo desconforto porque só a pouco tempo voltei a ter contato, de forma profissional, com a língua. É uma atividade bem menos espontânea do que a escrita em português, com a qual me sinto bem mais à vontade.

2) Como foi durante o processo de escrita do texto? O que você fez primeiro? Você usou a folha de rascunhos? Para quê, exatamente: para anotar suas idéias ou para escrever o texto e depois corrigi-lo?

- Primeiramente, escolhi o tema sobre o qual eu achava que falaria com mais facilidade. Pensei sobre o assunto e anotei na folha de rascunho algumas palavras ou expressões em forma de tópicos, e pensei um pouco sobre elas. Depois passei a escrever um parágrafo, seguido dos outros, a partir daí, veio a ordem do texto. Reescrevi na folha principal algumas passagens, outras excluí.

3) Quais foram as suas principais dificuldades na hora de escrever (organizar as idéias, definir uma opinião em relação ao assunto do texto, falta de vocabulário, falta de conhecimento gramatical para desenvolver as idéias etc)? 
A princípio, o vocabulário me fugiu, foi necessário um esforço extra para relembrar das palavras. As idéias me vinham com uma certa facilidade, contudo na tradução mental, não tinham a mesma forma. Fora isso, a estrutura das frases, principalmente por conta da regência, tinham que ser refeitas, corrigidas...

De um modo geral, as respostas de NA confirmam suas concepções tradicionais de língua e escrita. NA relaciona a atividade de escrita realizada no primeiro dia de aula à proposta do curso de praticar a escrita ${ }^{43}$ e, nesse sentido, demonstra entender 'prática' como 'treinamento' e, portanto, escrita apenas como demonstração de conhecimentos lingüísticos e não como prática social (“Achei que o teste fazia parte do objetivo do curso, uma espécie de tarefa prática, já que é disso que o curso trata"). Além disso, os problemas a que NA se refere dizem respeito basicamente a questões de vocabulário e gramática ("A princípio, o vocabulário me fugiu [...] As idéias me vinham com uma certa facilidade, contudo na tradução mental, não tinham a mesma forma. Fora isso, a estrutura das frases, principalmente por conta da regência, tinham que ser refeitas, corrigidas..."). Por outro lado, essa atividade propiciou a reflexão por parte de NA sobre seus sentimentos em relação à escrita, comparando-os com suas experiências de escrita em português ("Escrever em inglês me causa [...] um certo desconforto [...] $E$ ' uma atividade bem menos espontânea do que a escrita em português, com a qual me sinto bem mais à vontade").

Após a segunda aula, em que a instrutora apresentou os materiais de apoio e os alunos assistiram ao filme 'Freedom Writers', NA fez o seguinte depoimento em seu diário:

\footnotetext{
${ }^{43}$ A proposta de praticar a escrita aparece no título do curso: 'Praticando a escrita em inglês por meio de gêneros textuais: a argumentação'.
} 
First of all, I want to say that I am really happy with taking part of this new group. As I said before, this is a special moment in my life, because I feel like I am 'making peace' with academy, after a certain time of distance.

In our last class, it was clear for me that the teacher was worried about the pressure maybe we suffer when we receive much information that the course provides. I liked very much her observation, because I often feel quite lost when something new comes to me, mainly because I do not know how to filter it. For example, I was really exciting when I heard about the tools we should use to write better. My first wish was to run to a book store and take all the dictionaries! My mind has received an order! Of course, it was not the teacher's intention.

And talking about teachers' intentions, in the second part of the class, we saw the movie 'Freedom Writers', on which the main role was a teacher (The protagonist is Hilary Swank, an actress whom I saw for the first time when I was 12 or 13, on the movie 'The Next Karate Kid'). This film moved me in a special way, mainly because the teacher (of a public high school, placed in a poor and violent district) is an idealist woman, whom takes the responsibility of contributing to the dreams of a kind of student that probably does not know what a dream is. So, that is her challenge! The movie is great because shows us all the process of this teacher's challenge, including the fears, critics, disillusions etc. I think that the idea of 'process' in our life makes some deep difference.

Reading the article of Marie Foley about the 'five-paragraph essay,' this same idea reappears and makes sense. To predict a formula or a limit for someone express what comes in your mind through the use of words in writing can stimulate to write a specific activity, with a specific theme, but is it sufficient to stimulate a composition of a coherent text? That is the point! The concept of formula seems to be the opposite of process. The expression of ideas or feelings does not obey the same order in everybody. Our mind has no limit, and in spite of it, it can be coherent. To name the task of writing as a 'journey' is a very assertive Foley's idea, in my opinion. Journey is something connected with process, because in a journey, many things, good or bad, can happen, however, an objective exists. In our group, a new journey of writing is just beginning...

As declarações de NA são muito interessantes e reveladoras. Em relação aos materiais de apoio, NA demonstra não apenas ter compreendido o objetivo da instrutora de apresentar manuais de escrita, gramáticas e dicionários como material de consulta e não conteúdo ou foco do curso ("In our last class, it was clear for me that the teacher 
was worried about the pressure maybe we suffer when we receive much information that the course provides"), mas também ter compreendido suas próprias ações e crenças em relação a esses materiais ("I was really exciting when I heard about the tools we should use to write better. My first wish was to run to a book store and take all the dictionaries! My mind has received an order! Of course, it was not the teacher's intention"). Podemos dizer que essa ação de reflexão iniciou um processo em direção a uma mudança. No entanto, como já mencionamos, antes que a mudança efetivamente ocorra, a nova crença deve ser testada para ser incluída no sistema de crenças já existente, um processo que envolve tempo.

Em relação ao filme, NA demonstra ter compreendido o desafio enfrentado pela protagonista como um processo em direção a uma mudança em função de um propósito, ainda que idealista ("[...] the teacher (of a public high school, placed in a poor and violent district) is an idealist woman, whom takes the responsibility of contributing to the dreams of a kind of student that probably does not know what a dream is [...] The movie is great because shows us all the process of this teacher's challenge [...]"). No entanto, NA não explicita o papel que teve a escrita nesse processo e nem produz dados que revelam a realização de uma reflexão sobre a natureza social e cognitiva da escrita, como objetivava a instrutora, que poderia, por sua vez, levar à mudança de suas crenças em relação à língua e à escrita.

Em seu comentário sobre a leitura de Foley (1989), NA relaciona a ideia de processo à escrita ("The concept of formula seems to be the opposite of process"), revelando uma ação de reflexão que conduz a uma concepção processual de língua e escrita ("The expression of ideas or feelings does not obey the same order in everybody. Our mind has no limit, and in spite of it, it can be coherent.To name the task of writing as a 'journey' is a very assertive Foley's idea, in my opinion. Journey 
is something connected with process, because in a journey, many things, good or bad, can happen, however, an objective exists [...]"). Nesse sentido, ainda que não podemos afirmar que ocorre mudança em suas concepções de língua e escrita (pelos motivos já mencionados), o movimento em direção a ela (propiciado pela reflexão estabelecida) ocorre. No entanto, é um movimento de mudança em direção a concepções de língua e escrita relacionadas à abordagem processual e não social.

Em seu próximo depoimento, NA faz uma reflexão sobre o conceito de necessidade relacionado à escrita e inicia, dessa forma, um movimento de mudança em direção a concepções mais sociais de língua e escrita:

São Paulo, October of 2010.

I would like to start making a reflection about the idea of necessity. This word, so important in our lives, appeared in the end of our last class, and it comes to me now because 'necessity' is what I am looking for writing this diary (rsrsrs...).

I used to talk about this matter with a friend, who is psychoanalyst, and I remember that when I complain to her about my life, saying something like: "Oh, I miss my friends...", or "I miss my ex-boyfriend...", "I miss my family...", "I need a new house..." etc, she always talks to me: "Nana, lack is the beginning of everything", and she completes that it is because of the lack we feel, we are motivated to build a better situation. If everything is ok, we just can rest in peace! rsrs... Hence, I comprehend that necessity comes from lack, and makes us to search for things - then without necessity, it is so hard to realize something new being created.

To link this idea to the task of writing, it is something relevant to think about motivation, which appears after some kind of necessity of expression. It is easier to me, for example, to write a little about my life in the diaries, because it is a real necessity of my present days, and this space fulfils this function. Of course, it is not the only reason to write for this course, but it is the way I try to create other necessities, that will be more rational, I hope... 
Nessa reflexão (não motivada por nenhuma pergunta feita pela instrutora), NA demonstra compreender a relação entre escrita e necessidade ou propósito cognitivo/pessoal e social, revelando um movimento em direção a concepções mais próximas da abordagem social para o ensino da escrita ("It is easier to me, for example, to write a little about my life in the diaries, because it is a real necessity of my present days, and this space fulfils this function"). NA demonstra também perceber a relação existente entre a escrita significativa e as dificuldades enfrentadas/envolvidas nesse processo. Como já mencionamos, esse era um dos objetivos da instrutora: levar os alunos a perceberem que a utilização da escrita em situações significativas, como instrumento para realização de atividades reais (cognitivas ou sociais), gera dificuldades diferentes das mencionadas por eles (referentes apenas à gramática e a vocabulário), uma vez que a escrita não estaria servindo apenas para avaliação desses aspectos da língua. Nesse caso, as dificuldades estariam relacionadas ao conhecimento sobre o funcionamento da língua frente às diferentes situações/necessidades que estivesse envolvida, ou seja, o grau de dificuldade seria diretamente proporcional ao grau de conhecimento do $A C P$ que indica, por sua vez, de que forma os elementos do contexto se relacionam nas diferentes culturas formando os diferentes gêneros existentes.

Nesse ponto, apresentaremos os últimos dados produzidos por NA em seu diário, referentes às discussões sobre a língua e a escrita realizadas em aula:

I was really impressed in our last class, I think it was very profitable, because I feel that our group is developing a great empathy. Everybody seems to feel more comfortable to give opinions and discuss them especially myself. The teacher suggested us to think about the first signs of language that children usually demonstrate, and I feel invited 'to come back' to my childhood and remember my own previous history, as an attempt to discover the origin of my difficulties nowadays. 
The first question was: why is it easier for children to learn a second language? Why is it so hard, most of time, for adults?

The main idea is that they are able to acquire more than one language at the same time - when they are stimulated to - because their linguistic structures are in formation, so the interferences between them are minimum. Moreover, language is connected to the universe of these small people, who need to attract attention firstly to be provided in their basic necessities, hence the oral sentences used to be short and limited. Summing up, language acquisition in our childhood is firstly associated to survival. But, when we grow up, language tends to become more sophisticated, associated to activities as complex as an adult's life used to be. So the second language should be 'adult', as well. That is the difficulty: most of times, it does not happen! In this case, we should always to connect the second language to a larger universe, because if we do not, we can communicate as adults in our mother language, and as a child in our second one. It is funny, isn't it?

Another point discussed was about the concept we have on the task of writing. Writing is a kind of language skill which does not make part of our ordinary activities, few people cultivate this habit, and it is one of the great differences between writing and speaking. Of course, I am not considering that writing linked to virtual communications, like emails, chats etc. I refers to the habit of compose texts which requires abstraction - that is, complex thoughts.

A diary, for example, is a text that contains several moments of abstraction. When I describe my day for myself, I can think about the facts in a different way. For example, I can create situations based on real happenings, or remember past facts and mix to the present ones, even without a previous intention.

Generally, writing is required to specific purposes, mainly situations of evaluation, and this fact creates a great responsibility for people who are not stimulated for training this ability. We usually write under pressure! It seems to me that we learn to speak because of our necessities, but we have to create necessities to write. Maybe, that is the reason of learning speaking before writing in our culture. And if we are interested in achieve a life pattern better than 'trying to survive', the task of writing plays a great role in this process. This idea can explain the evaluations imposed to us through writing exams. And it is valid for mother or foreign language.

One of the alternatives to fill this gap are the courses called 'Instrumental English', on which several techniques to training students for reading and writing are taught. I remember that one of these techniques is nominated 'scanning', which means basically reading fast as a scanner machine does. It can be useful, but it does not consider the several stages for developing linguistic competences. However, it is an attempt to overcome this distance between oral and writing universes. 
What's the importance of a summary?

To produce a summary obliges us to a careful reading of the text, because the objective is to point out the sentences which better illustrates its main ideas. Moreover, it is useful as a guide to a general understanding of the text for someone who does not read it yet.

Qual a principal vantagem de se estar no país em que sua segunda língua é falada?

I think that living abroad can be a good experience that helps a student to be closer to the culture of his/her second language. But it is not a guarantee of becoming completely able to communicate, because it depends on the way the student intends to live in that place. Someone who accepts this adventure should be aware on the opportunity to take risks and practice most of time possible with the natives.

Como você define um bom falante? $\mathrm{E}$ um bom escritor?

A good speaker has a linguistic repertory adaptable to a different linguistic communities and situations. This idea is valid to a good writer, who also should be an interested and careful reader of the different text's typologies.

Em seu último depoimento baseado nas questões propostas pela instrutora, é possível observar que NA demonstra 1) perceber seu progresso e do grupo ("I feel that our group is developing a great empathy. Everybody seems to feel more comfortable to give opinions and discuss them - especially myself') e 2) ter desenvolvido certo controle do seu próprio processo de aprendizagem ("I feel invited 'to come back' to my childhood and remember my own previous history, as an attempt to discover the origin of my difficulties nowadays"). Por outro lado, NA faz interessantes observações 
sobre o processo de aprendizagem de língua estrangeira e sobre a escrita de um modo geral ("...] language acquisition in our childhood is firstly associated to survival [...] when we grow up, language tends to become more sophisticated, associated to activities as complex as an adult's life used to be"). NA demonstra compreender como a língua está relacionada às necessidades práticas dos indivíduos nas diferentes sociedades, indicando, dessa forma, o início de um processo de mudança em suas concepções tradicionais de língua e escrita. Em sua reflexão, NA consegue entender porque aprender a escrever (seja em língua materna ou língua estrangeira) constitui uma atividade árdua (e geradora de tantos sentimentos negativos como os mencionados por ela mesma): "Writing is a kind of language skill which does not make part of our ordinary activities, few people cultivate this habit, and it is one of the great differences between writing and speaking". E o mais interessante é que ela demonstra perceber a diferença entre a escrita utilizada para simples comunicação no dia a dia, praticamente sinônimo da fala, e a escrita relacionada às diversas práticas sociais e, portanto, gêneros textuais, que corresponderia à modalidade que as pessoas não estão acostumadas a utilizar: "Of course, I am not considering that writing linked to virtual communications, like emails, chats etc. I refers to the habit of compose texts which requires abstraction $[\ldots]$ ".

NA prossegue sua reflexão e chega a mais uma interessante conclusão, tendo como base sua própria experiência com a escrita: “Generally, writing is required to specific purposes, mainly situations of evaluation [...] We usually write under pressure! It seems to me that we learn to speak because of our necessities, but we have to create necessities to write. Maybe, that is the reason of learning speaking before writing in our culture" . Ela consegue perceber que a escrita, diferentemente da fala, não está relacionada às necessidades práticas na nossa cultura, mas que se restringe 
a situações de avaliação (que, por sua vez, atestam sua importância) e que, por isso, seria preciso criar necessidades para se escrever que vão além desse contexto, uma vez que a escrita constitui elemento fundamental para se progredir na vida ("[...] And if we are interested in achieve a life pattern better than 'trying to survive', the task of writing plays a great role in this process").

Podemos concluir que a atividade de reflexão realizada por NA em seu diário, propiciada pelas questões propostas pela instrutora e baseada nas explicações e discussões em aula, possibilitou a criação de uma zona de desenvolvimento potencial que levou a um processo de mudança de suas concepções. No entanto, como já mencionamos anteriormente, em relação à $\mathbf{M A}$ e à $\mathbf{D I}$, não podemos afirmar que ocorreu efetivamente uma mudança uma vez que esta constitui um processo complexo que demanda tempo para que as novas crenças sejam testadas e englobadas em nossos sistemas de crenças.

\subsubsection{Análise do diário de RE}

Os dados produzidos por RE no início do curso revelaram, como vimos, concepções tradicionais de língua e escrita, assim como ocorreu com as demais participantes. Apesar de RE ter mencionado objetivos categorizados como 'profissional e/ou acadêmico' (“[...] fazer um abstract [...]”; "Quero estar apta a [...] redigir e-mails em inglês”), apresentou também objetivos incluídos nas categorias 'escolar' (“escrever de forma apropriada e eficaz [...] na hora de usar uma 'preposition', ou uma 'collocation' ou uma 'phrasal verb"”; "Quero estar apta a compor essays"; “[...] internalizar as regras da escrita") e 'emocional' (“[...] não sinto uma segurança total na hora de redigir $[\ldots]$ "; "escrever $[\ldots]$ sem sofrer $[\ldots]$ "; “[...] perder a sensação 
de estar em uma "prova de fogo" [...]"; "[...] tornar mais natural a prática da escrita em inglês").

Nesse ponto, analisaremos as respostas de RE às primeiras perguntas feitas pela instrutora em seu diário, referentes à atividade de produção escrita aplicada no primeiro dia de aula. Suas respostas bem como as perguntas encontram-se reproduzidas abaixo:

1) Como você se sentiu quando a instrutora disse que após o intervalo vocês fariam uma atividade de produção textual em forma de teste? Como você se sente quando tem que escrever em inglês? E na sua língua materna? Qual a diferença?

Acho que me senti normal e um pouco ansiosa, para dizer a verdade. Acredito que passado anos de estudo, hoje me sinto caminhando para uma maturidade na escrita em língua inglesa. I've really liked this experience, porque esperava escrever all the time in English neste curso.

Com relação a como me sinto quando escrevo em inglês, direi que depende da situation. Quando escrevi sobre o filme Freedom Writers, que vimos na segunda aula, por exemplo, me senti a vontade para usar o inglês. Parecia que eu não estava under pressure, e me soltei para usar o que eu sabia. Foi natural. Quase não acreditei!

Quando escrevo em português, sinto-me muito bem. Gosto, sempre gostei e independentemente do texto, fico à vontade para redigir, pois vivencio a língua escrita diariamente. Mesmo que eventualmente eu titubeie em alguma estrutura, sei que terei muitas outras para substituir e assim continuar tecendo o meu texto.

A diferença entre uma e outra é simplesmente o fato de uma ser materna e a outra não. Invariavelmente sempre sentirei a "naturalidade" em escrever em português, pois falo, penso, escrevo, enfim tenho essa língua internalizada, ao passo que o inglês unfortunately será resultado de uma busca contínua e ininterrupta. Ainda que digamos que assim também se dá com a língua materna (ou seja, precisamos estudá-la, para então internalizá-la, dominando-a definitivamente depois de um determinado período), parece-me difícil termos esse mesmo domínio definitivo mesmo se cessarmos os estudos e aprimoramentos na língua estrangeira.

2) Como foi durante o processo de escrita do texto? O que você fez primeiro? Você usou a folha de rascunhos? Para quê, exatamente: para anotar suas idéias ou para escrever o texto e depois corrigi-lo? 
Sempre uso a folha de rascunho. Nela já vou escrevendo o texto como o idealizo, e então releio e vou corrigindo. Para mim é fundamental, pois sempre corrijo um ou outro aspecto, so it's absolutely important! No momento da transição do texto do rascunho para a folha de teste, pude ver estruturas que deveria corrigir, organizar um ou outro trecho, reposicionando-os ou os reescrevendo.

3) Quais foram as suas principais dificuldades na hora de escrever (organizar as idéias, definir uma opinião em relação ao assunto do texto, falta de vocabulário, falta de conhecimento gramatical para desenvolver as idéias etc)?

Organizar as ideias no papel definitivamente é um dos pontos mais críticos! Pois sempre fico analisando por onde começar, para então definir a estrutura textual, o vocabulário e registro, and so on. Quando escolhi o assunto, me pus a pensar como poderia iniciar aquele texto sendo o mais clara e coerente o possível, pois afinal queria escrever um texto bem organizado e que expressasse a minha opinião como a idealizara. Por fim, I think I did it. I hope! Pensei na estrutura do texto e no que queria comentar sobre travelling abroad. Defini que seria de uma forma gradativa, iniciando por questionamentos, pois era assim que me encontrava, até apresentar uma conclusão resolutiva, que mostrasse a ponderação dos questionamentos iniciais e o seu respectivo resultado.

As respostas de $\mathbf{R E}$ revelam o início de um movimento em direção à mudança de suas concepções. Apesar de utilizar expressões que confirmam suas concepções tradicionais de língua e escrita, ao revelar, por exemplo, que compreende o aprendizado da língua estrangeira como “[...] resultado de uma busca contínua e ininterrupta”, RE realiza uma reflexão sobre seus sentimentos e suas dificuldades que apontam para concepções ligadas às abordagens social e processual, respectivamente. RE consegue perceber a relação diretamente proporcional entre o uso significativo/natural da escrita e os sentimentos positivos dele advindos (“Com relação a como me sinto quando escrevo em inglês, direi que depende da situation. Quando escrevi sobre o filme Freedom Writers, que vimos na segunda aula, por exemplo, me senti a vontade para usar o inglês. Parecia que eu não estava under pressure, e me soltei para usar o que 
eu sabia. Foi natural. Quase não acreditei!'). Ela praticamente consegue explicar as causas dos sentimentos de dor, artificialidade e insegurança que mencionou em seus primeiros dados: o fato da escrita estar na maioria das vezes em sua vida ligada a situações de avaliação (em que a escrita é realizada sob pressão) e não a necessidades práticas que naturalmente surgem no dia a dia. Por outro lado, o fato de ter mencionado uma dificuldade diferente da anteriormente citada em seus primeiros dados (“Organizar as ideias no papel definitivamente é um dos pontos mais críticos!'”, confirma esse processo de mudança, refletindo concepções ligadas à abordagem processual de ensino da escrita.

Vejamos, agora, os comentários de RE sobre a leitura de Foley (1989):

Gostaria apenas de comentar sobre os primeiros textos que li. São realmente empolgantes, e para mim foi inusitado o do Five-paragrah Essays, pois já desconfiava que realmente sempre fomos condicionados a escrever de acordo com um "molde preestabelecido", mas não tinha a real noção de o quanto isso é universal e limitador no que se refere ao desenvolvimento criativo de qualquer composição escrita.

Após a leitura desse texto, percebi no que tinha "pecado" em redações anteriores, o porquê nunca ficava completamente bom um texto em que até me empenhava por horas; era o engessamento que não percebia. No curso de idiomas que faço semanalmente foi a mesma coisa, passei a perceber que aquele molde pré-fabricado estava transformando as redações em meros "produtos de linha de produção" para checar se os alunos estão adotando cada conteúdo novo abordado em sala de aula.

Bem, pelo menos agora, tentarei escrever de uma maneira menos "engessada", focando nas ideias que necessitarei sustentar no texto, e talvez assim eu passe a compor de uma melhor forma e que tenha o "quê" que antes sempre faltou!

Por meio da reflexão que realiza, RE se conscientiza sobre aspectos da escrita que a fazem migrar de concepções tradicionais para concepções mais ligadas à 
abordagem processual de ensino. Ela consegue explicitar e confirmar suas crenças sobre a ineficácia de abordagens baseadas em modelo para o ensino da escrita (“[...] já desconfiava que realmente sempre fomos condicionados a escrever de acordo com um "molde preestabelecido", mas não tinha a real noção de o quanto isso é universal e limitador no que se refere ao desenvolvimento criativo de qualquer composição escrita") e sobre a utilização da escrita apenas como instrumento para avaliação da aprendizagem do conteúdo que se ensina nas aulas de línguas ("No curso de idiomas que faço semanalmente foi a mesma coisa, passei a perceber que aquele molde préfabricado estava transformando as redações em meros "produtos de linha de produção" para checar se os alunos estão adotando cada conteúdo novo abordado em sala de aula"). Em sua reflexão, fica claro também, como RE consegue avaliar e controlar seu próprio processo de aprendizagem: “Após a leitura desse texto, percebi no que tinha "pecado" em redações anteriores, o porquê nunca ficava completamente bom um texto em que até me empenhava por horas; era o engessamento que não percebia" [...] Bem, pelo menos agora, tentarei escrever de uma maneira menos "engessada", focando nas ideias que necessitarei sustentar no texto, e talvez assim eu passe a compor de uma melhor forma e que tenha o "quê" que antes sempre faltou!".

A seguir, analisaremos o comentário de RE sobre o filme 'Freedom Writers':

\author{
About Freedom Writers
}

I really liked this film. It was one of the most impressive films of this genre I've ever seen, whose the strongly story made me wondering about one thing that I had closed in my mind, the mission called education. Besides, the perspective showed in the movie is ahead of we are accustomed to see. The teacher is such an engaged in save that children from violence and marginality that she applies herself totally to work. 
Another thing I loved in this film was the purpose. She gets to reach her goal by the writing. But it's not a conventional way like a "Five-paragraph Essay". It's more. It's about life. She gives them the opportunity to write about themselves in a journal, in which they could write by themselves everything and anything they want, that is, in a personal way. From this project, the teacher could rescue them of the horrible life, and that kids reached the graduation in the high school, despite of all condemnation that everybody had done about them.

As for me, this story was a motivation for persecuting even more my dreams, because everything is possible if we try.

As expressões utilizadas por RE, em seu comentário sobre o filme, revelam sua compreensão sobre o importante papel da escrita (e não apenas da escola ou da professora) na vida dos personagens da história ("Another thing I loved in this film was the purpose. She gets to reach her goal by the writing. [...] From this project, the teacher could rescue them of the horrible life, and that kids reached the graduation in the high school, despite of all condemnation that everybody had done about them"). Principalmente, RE demonstra compreender que não foi por meio da escrita concebida sob o ponto de vista da abordagem tradicional que mudou a vida dos alunos, mas a escrita próxima da perspectiva conceitual, relacionada não apenas às atividades práticas, mas também cognitivas das pessoas, a escrita que faz sentido na vida dos indivíduos (“[...] But it's not a conventional way like a "Five-paragraph Essay". It's more. It's about life. She gives them the opportunity to write about themselves in a journal, in which they could write by themselves everything and anything they want, that is, in a personal way").

Nesse ponto, analisaremos os últimos dados produzidos por RE, referentes 1) à leitura de Hyland (1990), 2) à aula em que a instrutora usou convites de casamento para explicar o $A C P$ e 3 ) ao curso como um todo: 
Os convites de casamento foram exemplos muito produtivos dos gêneros textuais e suas características; no caso mais específico da argumentação, foi possível visualizar os conceitos de tenor, field e mode mesmo no menor texto no sentido espacial, representado pelo convite. Aprender que um texto, mesmo que não acadêmico, por exemplo, é carregado de influências socioculturais e de intenção persuasiva foi fundamental para pensar sobre como o texto é arquitetado para atingir um determinado propósito.

A elaboração dos fluxogramas para expressar as etapas da composição do gênero foi muito importante para ajudar a fixar $e$ principalmente simbolizar por meio de esquemas o processo que envolve vários elementos (culture, tenor, field, mode) até alcançar o resultado pretendido.

Quanto ao texto discutido, A Genre Description of the Argumentative Essay, foi indiscutivelmente essencial para entender os mecanismos necessários para organizar o texto argumentativo. Leitura muito produtiva! Obrigada inclusive por me esclarecer quanto ao significado de "moves".

Agora, passado quase todo o curso de escrita, fico muito contente por ter tido a oportunidade de ler textos tão ricos e repletos de informações fundamentais sobre o processo de escrita e de ter participado de encontros que me ensinaram a pensar conscientemente sobre o processo de construção do texto. Mais um módulo desse curso seria muito bem-vindo!

As expressões utilizadas por RE demonstram, por um lado, sua conscientização sobre seu próprio processo de aprendizagem (“Aprender que um texto, mesmo que não acadêmico, por exemplo, é carregado de influências socioculturais e de intenção persuasiva foi fundamental para pensar sobre como o texto é arquitetado para atingir um determinado propósito [...] fico muito contente por ter tido a oportunidade de ler textos tão ricos e repletos de informações fundamentais sobre o processo de escrita e de ter participado de encontros que me ensinaram a pensar conscientemente sobre o processo de construção do texto") e, por outro lado, revelam como a produção de germcells (que, infelizmente, não foram avaliados por falta de tempo) também constituiu uma importante atividade para compreensão do ACP (“A elaboração dos fluxogramas para expressar as etapas da composição do gênero foi muito importante para ajudar a 
fixar e principalmente simbolizar por meio de esquemas o processo que envolve vários elementos (culture, tenor, field, mode) até alcançar o resultado pretendido [...]"). E em seu comentário sobre o texto de Hyland, RE demonstra entender como os gêneros são construídos a partir dos diferentes propósitos sociais a que servem ("Quanto ao texto discutido [...] foi indiscutivelmente essencial para entender os mecanismos necessários para organizar o texto argumentativo [...]”).

De um modo geral, podemos dizer que as reflexões produzidas por $\mathbf{R E}$ em seu diário e as atividades em geral realizadas por ela no curso (que se constituíram basicamente de interações por meio de reflexões e discussões baseadas em atividades de produção textual, leituras, filme, análise de amostras de gêneros e outros exercícios relacionados à escrita) propiciaram o início de um processo de mudança em suas concepções de língua e escrita para além da abordagem social, uma vez que ela demonstrou compreender, ainda que intuitivamente, o papel da escrita como instrumento simbólico para realização de atividades cognitivas no mundo, como ocorreu com os alunos do filme.

\subsubsection{Análise do diário de LU}

Como vimos na primeira etapa da análise, LU apresentou concepções tradicionais de língua e escrita, assim como as demais participantes. Apesar de ter mencionado objetivos categorizados como 'profissional e/ou acadêmico' (“[...] fazer o $C A E[\ldots]$ na escola onde trabalho é extremamente importante [...]"), compatível com seu perfil ${ }^{44}, \mathbf{L U}$ também apresentou objetivos incluídos na categoria 'escolar' (“practice my writing, improve it"). Além disso, LU apontou problemas com

\footnotetext{
${ }^{44} \mathbf{L U}$ é professora em uma escola de idiomas.
} 
vocabulário como sua principal dificuldade em relação à escrita ("Acho que as maiores dificuldades são quanto ao vocabulário [...]”).

Nesse ponto, iniciaremos a análise dos dados produzidos por LU ao longo do curso, começando por suas respostas às perguntas feitas pela instrutora em relação à primeira atividade de escrita que realizaram:

1) Como você se sentiu quando a instrutora disse que após o intervalo vocês fariam uma atividade de produção textual em forma de teste? Como você se sente quando tem que escrever em inglês? E na sua língua materna? Qual a diferença?

Senti-me tranquila, uma vez que tenho conhecimento que este é um curso de produção escrita, já era de se espera que em algum momento da aula isso iria ocorrer. Acho que prefiro escrever em inglês que em português. Só fiquei em dúvida ao ver as três opções, o mais complicado foi escolher, refletir e chegar a uma conclusão se meus argumentos seriam reais $e$ cabidos para o tema escolhido, se conseguiria expor o que desejava. Mas, é isso que espero do curso um direcionamento.

2) Como foi durante o processo de escrita do texto? $O$ que você fez primeiro? Você usou a folha de rascunhos? Para quê, exatamente: para anotar suas idéias ou para escrever o texto e depois corrigi-lo?

Prefiro fazer um levantamento dos tópicos a serem discutidos no texto, depois fiz um rascunho que ao passar para a folha final ainda é alterado. Algumas coisas que tinha escrito no rascunho foram mais desenvolvidas no final, além disso, é mais fácil de pensar quanto alguns spellings.

3) Quais foram as suas principais dificuldades na hora de escrever (organizar as idéias, definir uma opinião em relação ao assunto do texto, falta de vocabulário, falta de conhecimento gramatical para desenvolver as idéias etc)?

Ter argumentos consistentes para desenvolver o texto. Quando tenho que escrever ensaios, preciso de muita leitura anterior, acho que chego até a exagerar quanto ao input. Sinto-me mais segura na hora de argumentar, mas preciso criar um deadline, caso contrário, continuo lendo, lendo, lendo. 
As respostas de $\mathbf{L} \mathbf{U}$ às primeiras perguntas elaboradas pela instrutora revelam uma mudança de opinião em relação à sua principal dificuldade, que de vocabulário passou para organização dos argumentos ("“[... o mais complicado foi escolher, refletir e chegar a uma conclusão se meus argumentos seriam reais e cabidos para o tema escolhido, se conseguiria expor o que desejava"). Por outro lado, confirmam suas concepções tradicionais de língua e escrita ao entender prática de escrita como treinamento ("Senti-me tranquila, uma vez que tenho conhecimento que este é um curso de produção escrita, já era de se espera que em algum momento da aula isso iria ocorrer"). Diferentemente das demais alunas que, na primeira etapa da análise, expressaram sentimentos negativos em relação à escrita em inglês, LU afirma que prefere escrever em inglês do que em português ("Acho que prefiro escrever em inglês que em português").

Vejamos, agora, o segundo conjunto de dados, referentes à aula em que se realizou uma atividade em grupo sobre os elementos fundamentais para se escrever um bom texto:

I really had lots of information to think after last class, of course things are clear, but when we have to systematize and internalize we have to organize ideas and compare them to your own process in order to evaluate the rights and the wrongs about your writing.

For the first part of the class, we discussed about the list of what we consider fundamental to produce a satisfactory piece of writing. Our group started from: 
Tools (collocations, phrasal verbs, etc)

We thought we should have to main points, which we called content and audience, in our opinion you can write very well but if you do not know your audience it can be a disaster, and there is also another possibility, you know your reader, but do not know the content, so can write a piece which cannot be understood because it is nonsense or meaningless. After, we have the tools which can change the text according to the writer's knowledge of the language.

After the discussion, we could understand that the most important topic is language, if you do not have this knowledge you cannot write anything, there is no communication. So, knowing the system is the must, grammar is of great importance to be a good writer. The organization of the topics that best answers this is:

\begin{tabular}{|l|}
\hline language \\
\hline subject \\
\hline audience \\
\hline organizing ideas \\
\hline
\end{tabular}

For the second part of the class, we realized that for this method we as students have to work as scientists. There are some investigative steps we have to follow. I understood you are not going to provide us fixed formats, of course they exist, but you are always going to ask us in a way to 
investigate about what we already know, what we think about something and then we are going to feel we are able to reach that objective. We can internalize because we are a part of it, we are involved.

Then, we discussed about the differences from speaking and writing, the first one is the language in activity while the other one has to make sense with our reality, writing is a symbol of another symbol.

As I have already said, this things are crystal clear, but sometimes we do not realize, that is the why I am here, sometimes we have to be among other people talking and rearranging our own ideas.

As declarações de $\mathbf{L} \mathbf{U}$ revelam uma conscientização sobre seu próprio processo de aprendizagem e sobre a importância da reflexão e da discussão nesse processo para explicitação de crenças e compreensão efetiva dos fenômenos estudados ("[...] things are crystal clear, but sometimes we do not realize, that is the why I am here, sometimes we have to be among other people talking and rearranging our own ideas"). Por meio da atividade realizada em aula, LU pode compreender que o conhecimento da estrutura de uma língua é fundamental para a atividade de produção textual, no entanto, não constitui o único elemento para isso ("[...] We thought we should have to main points, which we called content and audience [...]").

Nesse ponto, analisaremos os últimos dados produzidos por $\mathbf{L U}$ e que se referem às perguntas propostas pela instrutora em seus diários sobre aspectos da língua e da escrita de um modo geral, questões, como já mencionamos, levantadas e discutidas anteriormente em aula:

Como uma criança aprende a falar? (É possível uma criança aprender duas ou mais línguas ao mesmo tempo? Por quê?) 
As criancas aprendem a falar por necessidade, elas entendem que serao atendidas e entendidas mais rapidamente se imitarem o que ouvem, pois uma vez que choram recebem a mamadeira e ouvem a mae dizer "dedera" ou "tete" por varias vezes ate que compreendem e entao com seu aparelho fonador em desenvolvimento vao reproduzindo o que acreditam ser o que ouviram. Entao, ou os pais comecam a falar corretamente ou esta crianca continuara falando de forma incorreta. Toda crianca que ouve uma lingua falada de maneira correta, falara corretamente tambem, da mesma forma que se ela estiver exposta a muitos erros, tambem os cometera. Por isso, ate, que ela entende melhor coisas paupaveis as abstratas.

Qual a principal diferença entre a forma como uma criança aprende sua língua materna e como um adulto aprende uma língua estrangeira?

A crianca fala por necessida, caso o adulto, que esta aprendendo uma segunda lingua, nao veja a necessidade de se comunicar, ele nao produzira. Alem disso, uma crianca nao se preocupa com regras gramaticais, ela simplesmente se comunica, e se faz entender. Ja um adulto, ao aprender um outro idioma, preocupa-se em comunicar-se de forma correta, tem de escrever tambem ao mesmo tempo, tudo isso usando a gramatica e o vocabulario corretamente.

O que a aprendizagem de uma ou mais línguas na infância promove na vida de uma criança? (Que impacto o aprendizado da língua tem na vida da criança? Pense no caso das meninas-lobo.)

A crianca aprende tudo a que for exposta, e quanto mais jovem, melhor. Ela tem a capacidade de aprender quantos forem os idiomas, pois elas nao os enxega desta maneira, para elas sao apenas signos que devem ser usados com diferentes interlocutores. Mas em momento algum os questiona, porque fala-se idiomas diferentes com pessoas diferentes. No caso das meninas lobo, elas foram expostas a uma vida animal durante muito tempo, e ao serem encontradas e resgatadas do mundo animal, nao conseguiram sobreviver, pois nao havia interacao.

O que é a escrita? É possível aprender a escrever antes de falar? Como você explica a eficácia (a existência) dos cursos de inglês instrumental, por exemplo, que ensinam apenas leitura. 
A escrita e a evolucao da fala, no entanto, so se consegue escrever, ou seja, se expressar pela escrita, quando ha uma reflexao da fala, sendo assim, pode-se concluir que a fala desenvolve-se a partir da necessidade na crianca, e tambem na escrita, mas posteriormente a reflexao. A eficacia dos cursos instrumentais advem do conhecimento do vocabulario peculiar a area que se esta estudando, mas isso nao quer dizer que o aluno seja fluente no idioma que se estuda, e sim que o vocabulario basico passa a ser reconhecido, outro aspecto, e a necessidade, lembre-se que a crianca aprende pela necessidade.

Qual a principal vantagem de se estar no país em que sua segunda língua é falada?

A exposicao, caso aproveite-se da chance de estar exposto $24 \mathrm{~h}$ por dia ao idioma, e veja a necessidade, a pessoa pode evoluir no seu aprendizado de outros idiomas.

Como você define um bom falante?

Um bom falante e aquele que se faz entender em diversos contextos. Ou seja, aquele que sabe se expressar de acordo com o seu interlocutor.

E um bom escritor?

Da mesma forma que um bom falente, podemos avaliar um bom escritor, pois escre diferente dependendo da necessidade.

Por que certos tipos de textos são mais fáceis de escrever do que outros?

Isso depende do que esta sendio chamado de texto. Se estivermos mencionando listas, e-mails, recados, e claro que sao faceis, pois fazem uso da maneira mais simples de se trabalhar com a lingua. Entretanto, se estivermos falando de dissertacoes, ensaios, artigos, a lingua deve ser trabalhada de uma forma mais inteligente, pois ha a necessidade de convencer seu interlocutor, ter o conecimento da retorica e ter poder de argumentacao. 
Por que é importante entendermos a relação língua-contexto? De que forma isso nos fará bons escritores?

Um interfere no outro e vice e versa, ja que se afz necessario o conhecimento cultural para que se escreva bem. E preciso saber sobre a cultura de um pais para que se desenvolva a escrita de acordo, ambos sao interdependentes.

O que uma abordagem para o ensino da escrita baseada em modelos pode acarretar?

Pode acarretar na falta de criatividade do escritor, enquanto que o que e mais importante e a forma, a escrita fica em segundo plano.

Na sua opinião, o que é gênero? Como surge um gênero?

Os generos surgem devido a necessidade e a padronizacao dos textos.

What's the importance of a summary?

In my opinion, we.have.to discuss the importance of wrting, and a summary is an exercise of writing, a way to practice writing and also how to organize ideas. I usually highlight a text while I'm reading it, then I rewrite the most important ideas, because the will help me when I have to write. Writing is a lovely exercise to interact with the former writer. I can talk to myself, I can check if I really understood the main point of the text and I can also question it. If I question it I know I still have to read or study about it, then I am free to write my own text, of course it's a result pof my point of view with some others'.

As respostas de $\mathbf{L U}$ às questões propostas pela instrutora revelam uma compreensão quase que completa dos principais conceitos trabalhados em aula, 
indicando, dessa forma, o início de um processo de mudança de suas concepções de língua e escrita. Por outro lado, ainda refletem a ausência da compreensão efetiva do $A C P$ e do conceito de gênero como sua manifestação concreta, um dos principais objetivos do curso. Esperava-se que os alunos entendessem os gêneros existentes como um resultado das relações relativamente estáveis (mas não fixas) entre os elementos do contexto (campo, relação, modo e cultura) e a língua e não como algo implantado artificialmente para padronização da comunicação, como demonstra compreender LU (“Os generos surgem devido a necessidade e a padronizacao dos textos”).

\subsubsection{Análise do diário de SA}

Como vimos na primeira etapa da análise, SA apresenta, no início do curso, concepções tradicionais de língua e escrita, assim como as demais participantes. Apesar de ter mencionado objetivos categorizados como 'profissional e/ou acadêmico' (“escrever artigos científicos"), compatíveis com seu perfil ${ }^{45}, \mathbf{S A}$ mencionou também objetivos incluídos nas categorias 'escolar' ("improve my writing abilities") e 'emocional' ("Considero que tenho certo bloqueio para a escrita [...]"). O aspecto emocional é considerado por SA como sua principal dificuldade (“É muito doloroso começar e sempre tenho desculpas para não continuar"). Além disso, SA praticamente não escreve em inglês em seu dia a dia ("A minha frequiência atual é nula $[\ldots] ”)$.

As respostas de $\mathbf{S A}$ às primeiras perguntas elaboradas pela instrutora em seu diário, referentes à atividade de produção escrita realizada no primeiro dia de aula, encontram-se reproduzidas abaixo:

\footnotetext{
${ }^{45}$ SA é doutoranda na área de Engenharia Química.
} 
1) Como você se sentiu quando a instrutora disse que após o intervalo vocês fariam uma atividade de produção textual em forma de teste? Como você se sente quando tem que escrever em inglês? E na sua língua materna? Qual a diferença?

Uma atividade em forma de teste significa avaliação e, conseqüentemente, a atribuição de uma nota. Não gosto de ser avaliada sem estar preparada. Considero que a minha nota será inferior. Mas parando para pensar, qual é o meu objetivo? Perfeição ou notas maiores que os dos colegas? $O$ ambiente escolar sempre foi comparativo e competitivo, né? Sempre tive notas altas no ensino médio e isto é considerado uma obrigação dentro da minha família. Mas tenho consciência de que este curso é para auxiliar no meu desenvolvimento e que os testes são parte deste método didático.

Sinto-me desconfortável para escrever em inglês, pois acho que o meu vocabulário é limitado e que irei cometer vários erros gramaticais. Entretanto, mesmo com um dicionário do lado e com acesso à internet, sinto-me desconfortável para redigir em inglês. Portanto, não conheço o real motivo para este desconforto.

Redigir em português também é desconfortável. Prefiro ler e pesquisar do que redigir um relatório. Por sinal, escrever um e-mail também é difícil. Isto já gerou muitas dificuldades na minha vida acadêmica e profissional.

A diferença entre a escrita nos 2 idiomas é que após o desbloqueio, a redação em português é mais produtiva. Por exemplo, na atividade de hoje deixei para o último minuto para redigir. Fiz tudo o que foi possível para evitar a escrita. É um tipo de procrastinação, certo? Ou é falta de disciplina, ou de comprometimento? Gostaria de resolver este problema ...

2) Como foi durante o processo de escrita do texto? O que você fez primeiro? Você usou a folha de rascunhos? Para quê, exatamente: para anotar suas idéias ou para escrever o texto e depois corrigi-lo?

Usei 2 folhas de rascunho. Na primeira escrevi todos os tópicos que vieram na mente, no estilo brainstorming. Separei os itens entre prós e contras do assunto, ordenei uma lógica de raciocínio e criei um exemplo. No verso da primeira folha escrevi o primeiro rascunho, riscando frases inteiras, trocando palavras. Na segunda folha escrevi o segundo rascunho e corrigi pequenos detalhes. Conforme as instruções, reli o texto, revi alguns itens. Finalmente passei a limpo o texto numa terceira folha.

3) Quais foram as suas principais dificuldades na hora de escrever (organizar as idéias, definir uma opinião em relação ao assunto do texto, 
falta de vocabulário, falta de conhecimento gramatical para desenvolver as idéias etc)?

Senti mais insegurança na falta de vocabulário. Depois tentei escrever da maneira mais simples possível para evitar erros gramaticais. A opinão sobre o assunto e a organização das idéias foram processos que fluiram naturalmente.

Se vocês conhecerem as suas dificuldades, será muito mais fácil superá-las por meio da instrução.

Com certeza! Este texto eu redigi naturalmente, sem o monte de muletas que utilizei para o texto de sábado passado. Como o texto não será avaliado $e$ as questões sugerem um desabafo das minhas dificuldades, resolvi escrever sem planejamento. Apenas pesquisei algumas palavras na internet, pois cometi erros de ortografia. Pretendo redigir o diário com mais antecedência e em inglês! Boa sorte para mim!

Em sua resposta à primeira pergunta, é perfeitamente possível perceber como a reflexão sobre seus sentimentos levou à explicitação/conscientização de suas crenças e instaurou um elemento de dúvida, promovendo, dessa forma, o início de um processo de mudança em suas concepções de língua e escrita: "Sinto-me desconfortável para escrever em inglês, pois acho que o meu vocabulário é limitado e que irei cometer vários erros gramaticais. Entretanto, mesmo com um dicionário do lado e com acesso à internet, sinto-me desconfortável para redigir em inglês. Portanto, não conheço o real motivo para este desconforto". A ação de reflexão propiciada pela pergunta em seu diário levou SA a perceber (praticamente sozinha) que a causa de seu desconforto e/ou bloqueio não estava simplesmente relacionado à gramática ou a vocabulário. Por outro lado, quando questionada sobre quais haviam sido suas principais dificuldades ao escrever, SA demonstra sua extrema preocupação com aspectos de vocabulário e gramática ("Senti mais insegurança na falta de vocabulário. Depois tentei escrever da 
maneira mais simples possível para evitar erros gramaticais"), confirmando suas concepções tradicionais de língua e escrita apresentadas no início do curso.

As expressões utilizadas por SA em sua resposta ao comentário feito pela instrutora após a apresentação das questões revelam como seu "desconforto" está ligado às situações de avaliação e pressão presentes em suas experiências com a escrita (“Este texto eu redigi naturalmente, sem o monte de muletas que utilizei para o texto de sábado passado. Como o texto não será avaliado e as questões sugerem um desabafo das minhas dificuldades, resolvi escrever sem planejamento"). Nessa reflexão, SA demonstra perceber essa relação e, baseando-se em sua experiência positiva recente com o português, motiva-se para escrever em inglês ("Pretendo redigir o diário com mais antecedência e em inglês! Boa sorte para mim!"). Diferentemente das demais participantes, que declararam não ter problemas com a escrita em língua materna (com exceção de $\mathbf{L U}$ que prefere escrever em inglês), as dificuldades apresentadas por SA estão relacionadas à escrita de um modo geral e não apenas à escrita em língua estrangeira. Nesse sentido, seu progresso em inglês poderá influenciar positivamente seu desempenho em língua materna.

Nesse ponto, analisaremos as declarações de SA sobre a aula em que houve a atividade em grupo para se elencar os elementos fundamentais para a produção de um bom texto. Seu depoimento encontra-se reproduzido abaixo:

This is my first diary in English and I'm very happy to achieve this goal. I really want to improve my writing skills and begin to communicate with the outside world. When I speak with someone in English, they always tell me my English is good. Now I must start writing to improve my academic carrier.

Last class began with group activity, discussing what's fundamental to produce a satisfactory piece of writing in a second language. I liked to list 
the items in order of importance. The most important is to learn the language and I consider my language knowledge (that includes grammar, vocabulary and collocations) very good for writing. The second one is knowing the subject in the language and I like very much to read and to make a research about anything. I'm not afraid to achieve this task in English. The third one is about the audience and this item is very important because you always begin to do your writing in the last minute this little detail may be forgotten. The last item is organizing the ideas. I'm really excited to learn more about it and [the teacher] told us that this a topic that will be very well discussed in the course.

The final discussion was about the questions:

"What's language?"

"What's writing?"

I liked very much to talk about the language like a process of communication with others and a process of thinking with yourself. That you need to feel the necessity of writing and this aspect is not developed in the schools. I felt very sad that I not observed this aspects and the process of writing was always painful for me.

That's all for now. I'm going to read the text of Martin, but I won't have time the write about it.

I'm so glad with myself that I finished my first diary in English.

O depoimento de SA revela o quanto as reflexões realizadas em aula e as propiciadas em seus diários foram fundamentais para sua compreensão da origem de seus problemas com a escrita ("I liked very much to talk about the language like a process of communication with others and a process of thinking with yourself. That you need to feel the necessity of writing and this aspect is not developed in the schools. I felt very sad that I not observed this aspects and the process of writing was always painful for me"). As expressões usadas por ela demonstram sua alegria e satisfação por estar escrevendo em inglês com prazer ("This is my first diary in English and I'm very happy to achieve this goal [...] I'm so glad with myself that I finished my first diary in English") e revelam o desejo de se comunicar por meio da escrita com o 
mundo ("I really want to improve my writing skills and begin to communicate with the outside world").

Em seu último registro no diário, SA apenas fez anotações sobre o que havia sido discutido em aula:

\section{Today we talked about :}

Relation between our course and the film;

Children learn faster than adult because the necessity. O aprendizado é mediado por adultos.

$O$ adulto vem com bagagem cultural e lingüística. They need study more and more.

The good speaker know to speak and ser entendido in every contexts.

The good writer know to write and

Saber usar a língua de acordo com os propósitos (contexto em geral)/ usar o tipo de linguagem para atingir os objetivos.

Para quem eu vou argumentar?

Vamos investigar a relação língua - contexto.

Como usar a língua para atingir os objetivos?

De um modo geral, podemos dizer que as reflexões e discussões realizadas em aula e as reflexões realizadas por $\mathbf{S A}$ em seu diário propiciaram uma mudança positiva na sua relação com a escrita, uma relação, a princípio, dolorosa e traumática ("I felt very sad that I not observed this aspects and the process of writing was always painful for me"). Em suas reflexões, SA chegou à conclusão de que as origens do seu "desconforto" e "bloqueio", tanto em inglês como em língua materna, relacionavam-se às experiências 
artificiais desenvolvidas no contexto escolar, restritas e limitadas às situações de avaliação para obtenção de nota. Nesse sentido, podemos dizer que foi iniciado um movimento em direção à mudança e que partiu da compreensão da origem de seus problemas com a escrita. No entanto, não podemos afirmar que ocorre efetivamente mudança em suas concepções de língua e escrita uma vez que não houve tempo suficiente para que ela pudesse ocorrer ou mesmo ser comprovada por meio de dados.

\subsection{Discussão dos resultados da $2^{\mathrm{a}}$ etapa da análise}

De um ponto de vista da perspectiva sócio-histórico-cultural, as crenças constituem um poderoso instrumento simbólico para a promoção do desenvolvimento integral do aluno, uma vez que envolvem, como os dados dessa pesquisa ajudam a confirmar, aspectos ligados à emoção, identidade e prática social. Apesar do curso não ter propiciado muitas oportunidades de experiências práticas com a escrita por meio da produção significativa de textos, as participantes puderam refletir sobre a atividade da escrita e sobre a origem de suas dificuldades e sentimentos negativos em relação a ela e conseguiram, dessa forma, iniciar um processo de mudança de suas concepções que as capacitou a 1) compreender, controlar e avaliar melhor seu próprio processo de aprendizado, 2) estabelecer uma relação mais positiva e menos traumática com a escrita e, por fim, 3) criou uma zona de desenvolvimento potencial para uma forma de uso mais significativa da escrita, como instrumento simbólico para a realização tanto de atividades práticas como cognitivas no mundo. Essa zona de desenvolvimento potencial foi construída por meio das interações, entre a instrutora e as participantes, em aula e em seus diários, e das reflexões decorrentes e que geraram, por sua vez, o início de um processo de mudança em suas concepções. 
Diante da situação em que se encontra o ensino da escrita nos dias atuais, como mostram os estudos de Ferreira (2011) e Rios (2010), pautado em abordagens tradicionais e até pré-tradicionais que concebem a escrita apenas como demonstração de conhecimento de aspectos da língua relacionados à gramática e a vocabulário (constituindo-se ao invés de prática social, apenas em instrumento de avaliação para nota) e, principalmente, as consequências desse tipo de ensino na vida futura dos alunos (gerando, inclusive, problemas emocionais que dificultam ainda mais a prática significativa e efetiva da escrita e a continuidade do processo de aprendizagem dos alunos), torna-se fundamental nos estudos sobre os processos de ensino e aprendizagem de línguas, o foco nas crenças dos alunos, dos professores e de todos os envolvidos nesse processo e, quando for o caso, na mudança dessas crenças.

Os dados produzidos pelas participantes dessa pesquisa revelam o quanto suas concepções tradicionais de língua e escrita - decorrentes, como discutimos na primeira etapa da análise, de suas experiências com a escrita no contexto escolar (desde escolas regulares, escolas de idiomas e até faculdades) - as privaram de experiências significativas com a escrita e constituíram um fator agravante na continuidade de seu processo de aprendizagem, gerando sentimentos negativos de insegurança, desconforto, dor, bloqueio, entre outros. Por outro lado, os resultados desse estudo confirmam muitas conclusões de estudos sobre crenças e mudanças de crenças, sobretudo, em relação às estratégias de reflexão e explicitação de crenças como formas de se promover a mudança. Nessa pesquisa, vimos vários exemplos de reflexões que levaram à conscientização dos alunos sobre vários aspectos referentes à língua e à escrita e promoveram o início de um processo de mudança em sua maneira de enxergar a escrita e em sua relação com ela, facilitando, dessa forma a continuidade do processo de aprendizagem. 
Outro aspecto que considero fundamental em relação a estudos que focalizam crenças de alunos, professores e demais envolvidos no processo de ensino e aprendizagem de línguas diz respeito à necessidade de se conceber crenças a partir de uma perspectiva teórica clara e como sugerem Barcelos (2007), Silva (2010) e Miccoli (2010), que se tenha como objetivos contribuir para o aprimoramento desse processo, como entendo que tenha ocorrido nessa pesquisa, em que as crenças não apenas foram identificadas, mas onde tentou-se utilizá-las para a promoção do desenvolvimento dos alunos por meio da intervenção com foco na mudança em contexto real de ensino. No caso desse estudo, as crenças foram concebidas do ponto de vista da perspectiva sóciohistórico-cultural e investigadas segundo a abordagem contextual, compatível com essa perspectiva. Nesse sentido, consideradas como instrumento simbólico, as crenças foram identificadas com o objetivo de serem transformadas e, dessa forma, promoverem o desenvolvimento cognitivo e a habilidade de escrita dos alunos. As palavras e expressões utilizadas pelas participantes em seus diários revelam claramente seu progresso e o início de um processo de mudança de suas concepções que, como mencionamos durante a análise de seus dados, depende de tempo para se concretizarem, uma vez que constitui um processo complexo que envolve a reestruturação de todo um sistema de crenças para a assimilação de novas.

Por outro lado, a não continuidade da intervenção que estava sendo realizada, em decorrência da curta duração do curso, não permitiu que a mudança nas concepções de língua e escrita dos alunos se concretizasse ou que se pudesse registrar tal mudança. Essa observação confirma as sugestões de Barcelos (2007) sobre a necessidade de estudos longitudinais na investigação de crenças e, principalmente, eu acrescento, nos estudos em que se objetiva a mudança de crenças e a sua utilização como instrumento 
simbólico para o desenvolvimento cognitivo dos alunos no contexto do ensino da escrita em inglês. 


\section{Considerações finais}

Este estudo objetivou investigar a mudança nas concepções de língua e escrita de seis alunas de um curso de escrita em inglês de extensão universitária, conduzido sob a perspectiva conceitual (FERREIRA, 2005). Utilizando como instrumentos os 1) planos e relatórios de aulas da instrutora-pesquisadora, 2) as respostas das participantes a perguntas de uma ficha de identificação e a uma questão dissertativa presente no teste de proficiência que realizaram para participar do curso e 3) as respostas às perguntas feitas pela instrutora e depoimentos em geral das participantes em diários dialogados enviados e recebidos por e-mail, a investigação pautou-se em uma abordagem contextual (BARCELOS, 2001), compatível com a perspectiva teórica geral adotada na pesquisa, a teoria sócio-histórico-cultural (VYGOTSKY, 1978, 1987).

A análise dos dados foi feita com base em Ferreira $(2005,2011)$ que aponta a existência de três principais abordagens para o ensino da escrita, tradicional, processual e social, das quais decorrem diferentes concepções de língua, escrita e seu ensino. A unidade de análise adotada correspondeu às palavras e/ou expressões utilizadas pelas participantes, bem como informações sobre o contexto em que foram produzidas, referentes aos seguintes aspectos: 1) seus objetivos em relação ao curso e/ou à escrita, 2) a frequência e a natureza das atividades em que utilizam e/ou utilizaram a escrita, 3) suas principais dificuldades em relação à escrita e 4) suas definições de conceitos relacionados à língua e/ou à escrita.

A seguinte pergunta de pesquisa foi elaborada: houve mudança nas concepções de língua e escrita dos alunos ao longo do curso? Para responder a essa pergunta de pesquisa, procuramos identificar as concepções de língua e escrita dos alunos, no início ( $1^{\mathrm{a}}$ etapa da análise) e ao longo do curso ( $2^{\mathrm{a}}$ etapa da análise). Os dados coletados no 
início do curso revelaram concepções tradicionais de língua e escrita por parte das alunas, representadas, principalmente, 1) pela crença na necessidade de conhecimentos relacionados à gramática e a vocabulário, 2) pela apresentação de objetivos categorizados como 'escolar' e 'emocional', 3) pela experiência mecânica e descontextualizada que tiveram com a escrita no contexto escolar e 4) pela ausência quase total de usos significativos da escrita em seu dia a dia. Os dados coletados ao longo do curso revelaram o início de um processo em direção à mudança por parte das alunas, propiciado pelas reflexões realizadas em aula e em seus diários.

Podemos concluir que esse estudo confirmou a importância do foco nas crenças e, principalmente, na mudança de crenças no processo de ensino e aprendizagem de línguas considerando-se, sobretudo, a realidade da maioria dos alunos, como os alunos dessa pesquisa, destituídos da possibilidade de utilizarem a escrita de modo significativo em seu dia a dia em decorrência de experiências artificiais e traumáticas com a escrita, ensinada apenas como instrumento de avaliação para nota e demonstração de conhecimento dos conteúdos trabalhados em aula e que, por sua vez, limitam-se a aspectos da língua relacionados à gramática e a vocabulário (FERREIRA, 2011; RIOS, 2010). Por outro lado, os resultados desse estudo confirmam, a nosso ver, a eficácia das estratégias de reflexão e explicitação de crenças para a promoção da mudança no contexto do ensino de línguas, mas também da necessidade de estudos e intervenções mais longitudinais que possam promover e registrar a mudança efetiva das crenças. 


\section{REFERÊNCIAS BIBLIOGRÁFICAS ${ }^{46}$}

ACTON, H. B. Dialectical materialism. In: EDWARD, P. (Ed.). The encyclopedia of philosophy. Vol. 2 New York: The Macmillan Co and the Free Press, 1967, p. 389-397.

APPEL, G.; LANTOLF, J. P. Theoretical Framework: an introduction to Vygotskian Approaches to second language research. In: APPEL, G.; LANTOLF, J. P. Vygotskian approaches to second language research. Norwood: Ablex. 1994, p. 1-31.

ARAÚJO, D. R. Crenças de professores de inglês de escolas públicas sobre o papel do bom aprendiz: um estudo de caso. Dissertação (Mestrado em Linguística Aplicada ao Ensino/Aprendizagem de Línguas Estrangeiras) - Faculdade de Letras, UFMG, Belo Horizonte, 2004.

. O processo de reconstrução de crenças e práticas pedagógicas de professores de inglês (LE): foco no conceito de autonomia na aprendizagem de línguas. In: BARCELOS, A. M. F.; VIEIRA-ABRAHÃO, M. H. (Orgs.) Crenças e ensino de línguas: foco no professor, no aluno e na formação de professores. Campinas, SP: Pontes, p.189-202, 2006.

BARCELOS, A. M. F. Metodologia de pesquisa das crenças sobre aprendizagem de línguas: estado da arte. Revista Brasileira de Linguística Aplicada, v. 1, n. 1, p.71-92, 2001.

. Reflexões acerca da mudança de crenças sobre ensino e aprendizagem de línguas. Revista Brasileira de Linguística Aplicada, v. 7, n. 2, p. 109-138, 2007.

BARCEloS, A. M. F.; VIEIRA-ABRAHÃO, M. H. (Orgs.) Crenças e Ensino de Línguas: foco no professor, no aluno e na formação de professores. Campinas, SP: Pontes Editores, 2006.

\footnotetext{
${ }^{46}$ De acordo com: ASSOCIAÇÃO BRASILEIRA DE NORMAS TÉCNICAS. NRB 6023: informação e documentação: referências: elaboração, Rio de Janeiro, 2002.
} 
BLATYTA, D. F. Mudança de habitus e teorias implícitas - uma relação dialógica no processo de educação continuada de professores. In: ALMEIDA FILHO, J. C. P. (Org.) O professor de língua estrangeira em formação. São Paulo: Pontes, 1999.

BIZZEL, P. Academic discourse and critical consciousness. Pittsburgh, PA: University of Pittusburgh Press, 1992.

BRUNER, J. Prologue to the English edition. In: VYGOTSKY, L. S. The collected works of L. S. Vygotsky: Vol 1. New York: Plenum, 1987, p. 1-16.

COE, R. M. An arousing and fulfillment of desires: the rhetoric of genre in the process era - and beyond. In: FREEDMAN, A.; MEDWAY, P. (Eds.), Genre and the new rhetoric. London: Taylor \& Francis, 1994, p181-190.

COLE, M.; SCRIBNER, S. Introdução. In: VIGOTSKI, L. S. A formação social da mente: o desenvolvimento dos processos psicológicos superiores. $7^{\mathrm{a}}$ ed. São Paulo: Martins Fontes, 2007, p. XVII-XXXVIII.

COPE, B.; KALANTZIS, M. Multiliteracies: literacy learning and the design of social futures. London: Routledge, 2000.

COPE, B.; KALANTZIS, M. Histories of pedagogies, cultures of schooling. In: B. C. a. M. Kalantizis (Ed.). The powers of literacy: a genre approach to teach writing. Pittsburgh: University of Pittsburgh Press, 1993, p. 38-62.

CUMMING, A.; NASSAJI, H. What's in a ZPD? A case study of a young ESL student and teacher interacting through dialogue journals. Language Teaching Research, 4 (2), 95-121, 2000.

DAVYDOV, V. V. Substantial generalization and the dialectical-materialistic theory of thinking. In: HEDEGAARD, M. P.; HAKKARAINEN; ENGSTROM, Y. (Eds.), Learning and teaching on a scientific basis. Aarhus, Denmark: Aarhus University Press, 1984, p. 11-32. 
. The concept of theoretical generalization and problems of educational psychology. Studies in Soviet Thought, 36, 1988, p. 169-202.

. What is real learning activity? In: HEDEGAARD, M.; LOMPSCHER, J. (Eds.), Learning activity and development. Aarhus: Aarhus University Press, 1999, p.123-138.

DELLAGNELO, A.; TOMITCH, L. Preferências de alunos-escritores em L2 com relação a estratégias de revisão de texto. Linguagem \& Ensino, 2 (1), p. 73-86, 1999.

DELPIT, L. The silenced dialogue: power and pedagogy in educating other people's children. Harvard Educational Review, 58, 280-298, 1988.

DUTRA, D. P.; OLIVEIRA, S. B. Prática reflexiva na formação inicial e continuada de professores de língua inglesa. In: BARCELOS, A. M. F.; VIEIRA-ABRAHÃO, M. H. (Orgs.) Crenças e Ensino de Línguas: foco no professor, no aluno e na formação de professores. Campinas, SP: Pontes, 2006, p. 177-188.

EMIG, J. The composing processes of 12th graders. Urbana, Il: NCTE, 1971.

ENGELS, F. Dialectics of nature. New York: International Publishers, 1940.

ENGSTROM, Y. Learning by expanding: an activity theoretical approach to developmental research. Helsinki: Orienta-Konsultit Oy, 1987.

FERREIRA, M. M. A concept-based approach to writing instruction: from the abstract concept to the concrete performance. 2005. 426 p. Tese (PhD em Linguística Aplicada) - Linguistics and Applied Language Studies Department, The Penn State University, State College, Pa, EUA, 2005. 
- Uma aplicação da abordagem pedagógica 'Movimento do Abstrato para o Concreto' para o ensino de gênero textual. Revista Solta a Voz, v. 20, n. 1, 2009, p. 115-129.

. O livro didático importado de inglês e o ensino da escrita (no prelo), 2011.

FERREIRA, M. M.; LANTOLF, J. P. A concept-based approach to teaching: writing through genre analysis. In: LANTOLF, J. P.; POEHNER, M. P. (Orgs.). Sociocultural theory and the teaching of second languages. London: Equinox, 2008.

FERRIS, D. The influence of teacher commentary on student revision. TESOL Quaterly, 31(2), 315-339, 1997.

FIGUEIREDO, F. Correção com os pares: os efeitos do processo da correção dialogada na aprendizagem da escrita em língua inglesa. 2001, Tese (Doutorado em Letras: Linguística Aplicada), Departamento de Estudos Linguísticos, Universidade Federal de Minas Gerais, Belo Horizonte, 2001.

FIGUEIREDO, F. Semeando a interação: a revisão dialógica de textos escritos em língua estrangeira. Goiânia: Ed. da UFG, 2005.

FLOWER, L.; HAYES, J. Problem solving strategies and the writing process. College English, 39, 365-387, 1977.

FLOWER, L.; HAYES, J. The cognition of discovery: defining a rhetorical problem. College Composition and Communication, 31, 21-32, 1980.

FLOWER, L.; HAYES, J. A cognitive process theory of writing. College Composition and Communication, 32, 365-387, 1981.

FOLEY, M. Unteaching the five-paragraph essay. Teaching English in the two-year 
college, 16,1989, p. 231-235.

FREEDMAN, A. Genre and the new rhetoric. London: Taylor \& Francis, 1994.

FULKERSON, R. Teaching the argument in writing. Urbana, IL: National Council of Teachers of English, 1996.

GALPERIN, P. Y. On the notion of internalization. Soviet Psychology, 5(3),1966, p. 28-33.

. Mental actions as a basis for the formation of thoughts and images. Soviet Psychology, 27(3), 1989, p. 45-65.

GARCIA, D. Os diários dialogados eletrônicos no ensino de língua estrangeira: a prática da escrita conectada a um ensino comunicativo para promover interação real. Linguagem \& Ensino, 7( 2), p. 17-36, 2004.

GASS, S.; MACKEY, A. Pushing the methodological boundaries in interaction research: An introduction to the special issue. Studies in Second Language Acquisition, 28(2), 169-178, 2006.

GEE, J. New people in new worlds: networks, the new capitalism and schools. In: Cope, B.; Kalantzis, M. Multiliteracies: literacy learning and the design of social futures. London: Routledge, 2000, p. 43-68.

GOLDSTEIN, L. M.; CONRAD, S. M. Student input and negotiation of meaning in ESL writing conferences. TESOL Quaterly, 24(3), 443-460, 1990.

HAENEN, J. Piotr Galperin: psychologist in Vygotsky's footsteps. Commack, NJ: Nova Science, 1996. 
HALLIDAY, M. A. K. Language as a social semiotic: the social interpretation of language and meaning. London: Edward Arnold, 1978.

HEDEGAARD, M. The zone of proximal development as basis for instruction. In: MOLL, L. C.; GREENBERG, J. B. (Orgs.). Vygotsky and education. Cambridge: Cambridge University Press, 1990. p. 349-371.

Learning and child development: a cultural-historical study. Aarhus: Aarhus University Press, 2002.

HEDEGAARD, M.; CHAIKLIN, S. Radical Local Teaching. Aarhus. Aarhus University Press, 2005.

HYONN, S. Genre in three traditions: implications for ESL. TESOL Quaterly, 30(4), 693-722, 1996.

HYLAND, K. A Genre description of the argumentative essay. RELC Journal, 21(1), 66-78, 1990.

ILYENKOV, E. V. The dialectics of the abstract and the concrete in Marx's capital. Moscow: Progress, 1982.

INGHILLERI, M. Learning to mean as a symbolic and social process: the story of ESL writers. Discourse Processes, 12, 391-411, 1989.

IZUMI, S.; BIGELOW, M.; FUJIWARA, M.; FEARNOW, S. Testing the Output Hypothesis. Effects of Output on Noticing and Second Language Acquisition. Studies in Second Language Acquisition, 21, p. 421-452, 1999.

IZUMI, S. Output, Input Enhancement, and the Noticing Hypothesis. An Experimental Study on ESL Relativization. Studies in Second Language Acquisition, 24 (4), p. 541577, 2002. 
KERN, R. Literacy and language teaching. Oxford: Oxford University Press, 2000.

KRASHEN, S. Principles and Practice in Second Language Acquisition. Oxford: Pergamon Press, 1982.

LEE, A. Gender, Literacy, Curriculum: re-writing school geography. London: Taylor \& Francis, 1996.

LANKSHEAR, C.; KNOBEL, M. New Literacies: Changing Knowledge and Classroom Research. Buckingham: Open University Press, 2003.

LEONTIEV, A. N. Activity, consciousness and personality. Englewood Cliffs, New Jersey: Prentice-Hall Inc, 1978.

LEONTIEV, A. N. Problems of the development of the mind. Moscow: Progress, 1981.

LONG, M. The role of the linguistic environment in second language acquisition. In: RITCHIE, W.; BATIA, T. K. (orgs). Handbook of second language acquisition. Academic Press: New York, 1996.

LOMPSCHER, J. Problems and results of experimental research on the formation of theoretical thinking through instruction. In: HEDEGAARD, M. P. et al. (Orgs). Learning and teaching on a scientific basis. Aarhus: Aarhus Universitet, 1984, p. 293-357.

Learning activity and its formation. In: HEDEGAARD; LOMPSCHER (Eds.), Learning activity and development. Aarhus: Aarhus University Press, 1999, p. 139166.

. The category of activity as a principal constituent of cultural historical psychology. In: Robins, D.; A. STETSENKO, A. (Eds.). Voices within Vygotsky's non-classical psychology:past, present, future (pp. 79-99). New York: Nova Science, 2002. 
LUKE, A. Genres of power? Literacy education and the production of capital. In: HASAN, R; WILLIAMS, G. (Eds.) Literacy in society. London: Longman, 1996, p. 308-338.

LUKE, C. Cyber-schooling and thecnological change. In: Cope, B. \& Kalantzis, M. Multiliteracies: literacy learning and the design of social futures. London: Routledge, 2000, p. 69-89.

LURIA, A. R. Cognitive development: its cultural and social foundations. Cambridge, Mass: Harvard University Press, 1976.

LURIA, A. R. The making of mind. Cambridge, Mass: Harvard University Press, 1979.

MAGALHÃES, M. C. C. A Linguagem na formação de professores como profissionais reflexivos e críticos. In: MAGALHÃES, M.C.C. (org.) A formação do professor como um profissional crítico: linguagem e reflexão. Campinas, SP: Mercado das Letras, 2004.

MARCUSCHI, L. Produção textual, análise de gêneros e compreensão. São Paulo: Parábola Editorial, 2008.

MARTIN, J. Factual Writing: exploring and challenging social reality. Oxford: Oxford, 1989.

MARTIN, J. Genre and literacy: modeling context in educational linguistics. Annual Review of Applied Linguistics, v.13, p.141-172, 1993.

MARTIN, J. Mentoring semogenesis: 'genre-based' literacy pedagogy. In: CHRISTIE, F. (Ed.). Pedagogy and the shaping of consciousness. London: Continuum, 1999. p.123-155. 
MEANEY, M. C. Argumentação na formação do professor na escola bilíngue. 2009. 149 p. Dissertação (Mestrado em Linguística Aplicada e Estudos da Linguagem) PUC, São Paulo, 2009.

MILLER, C. Genre as social action. Quaterly journal of speech, 70, 151-167, 1994.

OLIVEIRA, M. K. Vygotsky: aprendizado e desenvolvimento: um processo sóciohistórico. $4^{\mathrm{a}}$ ed. São Paulo: Scipione, 1998.

PAJARES, F. M. Teachers' beliefs and educational research: cleaning up a messy construct. Review of Educational Research, v. 62, n. 3, 1992, p. 307-332.

PESSOA, R. R.; SEBBA, M. A. Y. Mudança nas teorias pessoais e na prática pedagógica de uma professora de inglês. In: BARCELOS, A. M. F.; VIEIRAABRAHÃO, M. H. (Orgs.) Crenças e Ensino de Línguas: foco no professor, no aluno e na formação de professores. Campinas, SP: Pontes, 2006, P. 43-64.

PITELI, M. L. Conscientização das estratégias de aprendizagem voltadas para a leitura em língua estrangeira: investigação em uma escola pública. Dissertação de mestrado. UNESP, São José do Rio Preto, 2006.

RIOS, F. O processo do ensino da escrita em inglês como língua estrangeira em uma escola de idiomas. Monografia apresentada à disciplina Trabalho de Graduação Individual em Letras Modernas II, Departamento de Letras Modernas, USP, São Paulo, SP, 2010.

ROCHA, C. H. Um estudo exploratório sobre o ensino de inglês no fundamental I: foco nas crenças dos participantes. In: SILVA, K. A. (Org.) Crenças, discursos e linguagem. Campinas, SP: Pontes, 2010, p. 227-265.

ROJO, R. Letramentos Múltiplos, escola e inclusão social. São Paulo, Parábola Editorial, 2009. 
RUSSELL, D. Activity theory and its implications for writing instruction. In: J. Petraglia (Ed.), Reconceiving writing, rethinking writing instruction (p. 51-77). Mahwah, NJ: Lawrence Earlbaum, 1995.

SELZER, J. Rhetorical Analysis: understanding how texts persuade readers. In: C. Bazerman \& P. Prior (eds). What writing does and how it does it: an introduction to analyzing texts and textual practices. Mahwah, NJ: Lawrence Earlbaum, p. 279-307, 2004.

SQUIRE, J. R.; APPLEBEE, R. K. Teaching English in the United Kingdom. Champaign, Ill: NCTE, 1969.

SILVA, K. A. (Org.) Crenças, discursos e linguagem. Campinas, SP: Pontes, 2010

SILVA, K. A. da; ROCHA, C. H. Crenças sobre o ensino e aprendizagem de línguas na Linguística Aplicada, 1018 - 1047. Anais do I Congresso Latino-Americano sobre Formação de Professores de Línguas. Florianópolis, UFSC, 2007.

SILVA, T. Second language composition instruction: developments, issues, and directions in ESL. In: B. Kroll (Ed.), Second language writing: research insight for the classroom (p. 11-23). Cambridge: Cambridge University Press, 1990.

SOUZA, L. Ensino da produção escrita em língua estrangeira (inglês) em um curso de línguas: influência da avaliação ou da concepção de escrita do professor? Dissertação (Mestrado em Linguística Aplicada). Instituto de Estudos da Linguagem, Universidade Estadual de Campinas, Campinas, SP, 2002.

SPACK, R. Invention strategies and the ESL college composition student. TESOL Quaterly, 18(4), 649-670, 1984.

SWAIN, M. Communicative Competence: Some Roles of Comprehensible Input and Comprehensible Output in its Development. In: GASS, Susan \& MADDEN, Carolyn 
(orgs.). Input in Second Language Acquisition. Rowley: Newbury House, p. 235-253, 1985.

SWAIN, M.; LAPKIN, S. Problems in Output and the Cognitive Processes they generate: A Step towards Second Language Learning. Applied Linguistics, 16, p. 371$391,1995$.

SWALES, J. M. Genre analysis. Cambridge: Cambridge University Press, 1990.

TRIMBUR, J. Taking the social turn: teaching writing post-process. College Composition and Communication, 45, 108-118, 1994.

VIEIRA-ABRAHÃO, M. H. Metodologia na investigação das crenças. In: BARCElOS, A. M. F.; VIEIRA-ABRAHÃO, M. H. (Orgs.) Crenças e Ensino de Línguas: foco no professor, no aluno e na formação de professores. Campinas, SP: Pontes, 2006, P. 219-232.

VIGOTSKI, L. S. A formação social da mente: o desenvolvimento dos processos psicológicos superiores. $7^{\mathrm{a}}$ ed. São Paulo: Martins Fontes, 2007.

VIGOTSKI, L. S. Pensamento e linguagem. 4ª ed. São Paulo: Martins Fontes, 2008.

VYGOTSKY, L. S. (1978). Mind in society. Cambridge, Mass: Harvard University Press.

VYGOTSKY, L. S. The collected works of L. S. Vygotsky: Vol 1. New York: Plenum, 1987.

WERTSCH, J. V. Editor's introduction. In: WERTSCH, J. V. (Ed.). The concept of activity in Soviet psychology. Armonk, NY: Sharpe, 1981, p. 37-40. 
WOODS, D. Teacher cognition in language teaching: beliefs, decision-making and classroom practice. Cambridge: Cambridge University Press, 1996.

. The social construction of beliefs in the language classroom. In: KALAJA, P.; BARCELOS, A. M. F. (Orgs.) Beliefs about SLA: new research approaches. Kluwer Academic Publishers. Netherlands, 2003, p. 201-230.

ZAMEL, V. Writing: the process of discovering meaning. TESOL Quaterly, 16, 6776, 1982.

ZAMEL, V. The composing processes of advanced ESL students: six case studies, TESOL Quaterly, 17, 165-187, 1983.

ZAMEL, V. Responding to student writing. TESOL Quaterly, 19(1), 79-101, 1985. 
ANEXOS 


\section{Anexo A - Exame de proficiência}

\section{Exame de Proficiência (Inglês/nível intermediário)}

Nome:

RG:

Tel/E-mail:

A) Why do you think this course is important for you? How do you relate it to your personal or professional experience? Which goals do you expect to achieve through it? (Try to answer these questions writing a short text about the topic outlined by them) 
1. In medieval times__ his enemy by throwing down his gauntlet.
(A) the challenge
(B) a man challenged
(C) a man made a challenge
(D) his challenge

2. In 1885 photography changed dramatically introduced paper-based film.
(A) Eastman
(B) Eastman was
(C) when it was Eastman
(D) when Eastman

3. antitrust laws did not exist in the U.S., there would not be as much competition in certain industries.
(A) : So
(B) If
(C) For
(D) Also

4. A bat will often spend the daylight hours upside down in a tree or cave.
(A) hanging
(B) which hangs
(C) that is
(D) hangs

5. Geomorphology is the study of the changes that __ on the surface of the earth.
(A) taking place
(B) takes place
(C) take place
(D) they take place

(A) so much that
(B) it
(C) most
(D) as much as

9. The electric eel uses its electric shock to capture food and

(A) for protection

(B) protect itsel

(C) protecting itself

(D) it protects itself

10. Rarely _ acorns until the trees are more than twenty years old.
(A) when oak trees bear
(B) oak trees that bear
(C) do oak trees bear
(D) oak trees bear

11. The Andromeda Nebula, ___ more than two million light years away, can be seen from the Northern Hemisphere.
(A) a galaxy
(B) is a galaxy
(C) a galaxy is
(D) a galaxy which

6. A hero of the war of 1812 , _ _ president of the United States.
(A) Andrew Jackson later became
(B) that Andrew Jackson later became
(C) who was Andrew Jackson
(D) later became Andrew Jackson 
12. The closer to one of the Earth's poles, the greater ___ gravitational force.
(A) is
(B) the
(C) has
(D) it has

13. Baboons eat a variety of foods, __ eggs, fruits, grass, insects, plant leaves, and roots.
(A) they include
B). among them are
(C) among.
(D) including

14. The flamingo uses its bill ___ feeding to filter mud and water from the tiny plants and animals that it finds in shallow ponds.
(A) when
B) is
(C) that it is
(D) was

15. The first nuclear-powered ship in the world, the Nautilus; _ by the U.S. Navy in 1954
(A) when it was launched
(B). that was launched
(C) was launched
(C) was launchied

16. The larger of the forty-eight continental states in the United States is Texas.

17. According to the experts, genetic inheritance is probability $\frac{\text { the most important factor in }}{\mathrm{C}}$ determining a person's health D

18. The railroad was one of the first methods of transportation to be use extensively in early American history.

19. Often when the weather is extremely hot, people have very thirsty but are not terribly hungry.

20. Pioneers on the plains sometimes living in dugouts, sod rooms $\frac{\text { cut into hillsides. }}{\mathrm{D}}$

21. Balloons have been $\frac{\text { used in various wars not only to direct artillery fire and report troop }}{\mathrm{A}}$ movements however to carry bombs and protect against low-flying planes.

The National Wildflower Research Center which was established in 1982 by Lady Bird Johnson on sixty acres of land east of Austin.

23. The idea that artistic achievements rank in importance with scientific achievements has been A upheld by painters, writers, and.musicals for centuries.

24. To improvement the stability of the building, a concrete foundation two feet thick must be $\frac{\text { installed }}{\mathrm{D}}$

25. In 1786 Benjamin Franklin first suggested daylight savings time as a means of cutting down on the consumes of candles. 
26. An alligator is an animal somewhat like a crocodile, $\frac{\text { but }}{\mathrm{C}}$ with a broad, flatten snout.

27. An extremely dangerous forms of cocaine, crack attacks the nervous system, brain, and body in a sharper fashion than cocaine.

28. It is the role of the National Bureau of Standards to establish accurate measurements for science, $\overline{\mathrm{A}} \quad \frac{\mathrm{B}}{\mathrm{C}}$ $\frac{\text { industriall, }}{\mathrm{D}}$ and commerce.

\section{Questions 31-39}

In the beginning of the nineteenth century, the American educational system was desperately in need of reform. Private schools existed, but only for the very rich, and there were very few public schools because of the strong sentiment that children who would grow up to be laborers should not

Line "waste" their time on education but should instead prepare themselves for their life's work. It was in

(5) the face of this public sentiment that educational reformers set about their task. Horace Mann,

probably the most famous of the reformers, felt that there was no excuse in a republic for any citizen to be uneducated. As Superintendent of Education in the state of Massachusetts from 1837 to 1848 , he initiated various changes, which were soon matched in other school districts around the country. $\mathrm{He}$ extended the school year from five to six months and improved the quality of teachers by instituting

(10) teacher education and raising teacher salaries. Although these changes did not bring about a sudden improvement in the educational system, they at least increased public awareness as to the need for a further strengthening of the system.

31. Which of the following would be the most appropriate title for the passage?
(A) A Fight for Change
(B) Nineteenth-Century Reform
(C) American Education
(D) The Beginnings of Reform in American Education

32. It is implied in the passage that to go to a private school, a student needed
(A) a high level of intelligence
(B) a strong educational background
(C) good grades
(D) a lot of money

33. The word "sentiment" in line 3 is closest in meaning to
(A) action
(B) opinion
(C) sensation
(D) disagreement

36. According to the passage, why did Horace Mann want a better educational system for Americans?

(A) Education at the time was so cheap.

(B) In a republic, all citizens should be

$$
\text { educated. }
$$

(C) People had nothing else to do except go to school

(D) Massachusetts residents needed something to do with their spare time.

37. The word "initiated" in line 8 is closest in meaning to
(A) regretted
(B) broadened
(C) overturned
(D) started

34. Why is the word "waste" in line 4 punctuated in this manner?

(A) The author wants to emphasize how much time was wasted on education.

(B) The author is quoting someone else who said that education was a waste of time.

(C) The author thinks that education is not really a waste of time.

(D) The author does not want ștudents to waste their time on education.

35. What are "reformers" in line 5 ?
(A) People who try to change things for the better
(B) People who really enjoy teaching
(C) People who believe that education$$
\text { is wasted }
$$
(D) People who work for the government

38. The word "matched" in line 8 could best be replaced by
(A) observed
(B) equaled
(C) fitted
(D) burnt

39. According to the passage, which of the following is a change that Horace Mann instituted?

(A) Better teacher training

(B) Increased pay for students

(C) The five-month school year

(D) The matching of other districts policies 


\section{Anexo B - Ficha de identificação}

\section{FICHA DE IDENTIFICAÇÃO}

Nome:

Idade:

Nacionalidade:

Escolaridade:

Profissão:

1- Como você aprendeu inglês? Qual foi seu principal recurso (escola de idiomas, filmes, TV, livros, vivendo no exterior, conversando com falantes de inglês em casa ou por intercâmbio etc)? Por quantos anos você estudou inglês? A partir de que idade? (Conte sua história em relação ao aprendizado da língua inglesa)

2- Em que ocasiões e com que freqüência você usa o inglês? Como você avalia o seu desempenho? Está satisfeito? Quais são suas principais dificuldades?

3- Por que você se inscreveu neste curso? O que você espera que ele te proporcione?

4- Em que ocasiões você já escreveu (ou escreve) em inglês e com que freqüência?

5- Você está escrevendo algum texto em inglês atualmente? E no futuro próximo (2-3 meses)?

6- Você tem dificuldades em escrever em inglês? Se sim, quais são elas?

7- Como você avalia seu desempenho na escrita em português? (Ruim - bom - ótimo) Por quê? 
Anexo C - Respostas à questão A do Exame de Proficiência

MA

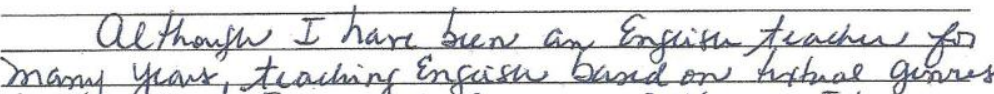
is Aomething I an not finsiliar vith, as I have always washed in lomgonde fchools, following thire specific methods

As worling initer textral gomes is a shong tendincy in formal sducation - ance a mist in privak schools where I han jist ftauted to work I beliese that the readings, exhcisis and discustions in this couse vile hep bre bethe undustand this Feaching appoach and, thufse, help one be a better tracker in the near fictore. 
DI

If finished my master gradecation on phd level at USP in 2005 and until now I didn't the paver exactly becacese I need to peet it into english langucge. Since I started to study enclish Ided all levels here, at FfLCH, and two lebels of Instumontel endrigh bere tro bet I don't fal weel to write in english and it's necenaryos "far my acodemic and proferrional caverel. (CARiliz). I'd like to do teies course in order to achieve this wanderfel hability! 
NA

THIS eOURSE IS IMRORTANT TO IMPROVE MY WRITINE A $20 T$ OF TRAINING TO THE ACADEMTIS, HENEE I NEED MOREOVER, I WORK WITH TRANSWATIS STUDIBS INGENERAR. HENEE BUT MANY TIMBS THE CLIENTS (ENB-G PORT) MAKE VERSIONS (PORT. ENE) CIENTS ABK ME TO IS GOINB TO HELR ME TO ACHIETE HORE THE COURSG AND VOCABULARY TO WRITS. I EXPECT HHATFIDENEG semester I will bG MORE EXPEeT that In this stizl. 
RE

Live been studied Bnglish for six years. Mly graduation at university was based on smglish studies. my fob ina Publishing howse, that f ve started in $20 B 7$ is focused

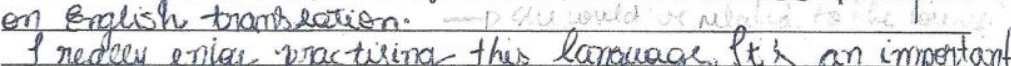
part of mi ele. I have dreams about travelling abrood. I always/loek for improvment. I terant to do rnv best. I hat is the resion. wing $f$ an here at this misment, writing this text, dispete of my fears and limitations en the enalish lonowase

I wish of was more prepared to use the language especially in Writing. So, then five knoun about this ecwnel fo was so glad arde excited! I expect to take pout of them, and learn everuthing that will be Elered. for my carrer and pertoral experusnce it will be exctremely important. 
LU

In mp opinon, this covive wiel help m a lot as I an a teccher of English. As nou Xrow, it is vevy simpstant to keep on studenge in any ana you are butas toaclens, I am sule lt is ar obligation.

On th other hand, I love English. Istudied it at univentity and also attendire to a course of English. Litactures kere at USP, what was guat becaux Scouid read arrol urite a liot. Is this year, thaver bew studying fo the CAE and thit is one more reasen fo being Lene. I thind it is a good opartu inty to pactice my witing, insperer it ar much on 30 cons, and exclange knowledge will be impotant too. 
SA

This writing course is important for me to impore my writing dbilities. In my effort to have more penency in english, I read english books and watele movies without or with english subtitles. But I think my writing is very poor. Actually I am a graduate student of the Escold plifecuics and in a sadenic corrier is very important to meblish articler in iuternational journals. I supponse that this course is not specific for scademic writing, but gon always have to argament a porint of view in a article. So my gool to achieve throught this course is having a good writing in english. 


\section{Anexo D - Respostas à Ficha de Identificação}

\section{MA}

Idade: 51

Nacionalidade: Brasileira

Escolaridade: Superior completo

Profissão: Professora

1- Decidi aprender inglês quando era criança, porque achava 'bonito' ver colegas mais velhos falando o idioma, cantando as músicas, etc. Mas só tive a oportunidade de iniciar um curso de inglês quando eu tinha uns 18 ou 19 anos (faz tempo, não me lembro mais - risos...). Após alguns anos fui convidada para lecionar na mesma escola onde estudava, fiz um curso (rápido) no exterior, e agora 'apreendo' com filmes, livros, TV a cabo, etc.

2- Reading and listening - praticamente todos os dias (TV, livros); writing and speaking, raramente. Gostaria de praticar mais a oralidade, e melhorar minha pronúncia.

3- Como eu mencionei na aula inaugural, fico frustrada quando não consigo ajudar um aluno que tem dificuldades em produzir um texto. Já conheço algumas 'técnicas' de escrita, que aprendi em outras ocasiões, mas gostaria de entender melhor o processo, ter uma visão mais 'científica'. Assim, busco aporte teórico para minhas reflexões e ações.

4- Escrevi muito enquanto estudava inglês 'formalmente', mas agora praticamente não o faço mais.

5- Em princípio, somente os propostos no curso.

6- Falta de vocabulário e um pouco de incerteza em relação às estruturas - principalmente uso de preposições e das 'collocations'.

7- Arrisco a dizer que entre bom e ótimo, porque consigo atingir meus objetivos de comunicação escrita sem grandes dificuldades. 
Idade: 43

Nacionalidade: Brasileira

Escolaridade: Pós-graduada (doutorado)

Profissão: Professora

1- Sou apaixonada por esta língua! Ela me foi apresentada na $5^{\text {a }}$-série do ensino fundamental, eu tinha 11 anos e já sábia q queria muito aprendê-la. A profa foi fantástica e só aumentou esta minha vontade de "dominar" o idioma. Iniciei, mais ou menos aos 15 anos, em escolas particulares muito fracas. Estudei com professores particulares até entrar no mestrado, como proficiente. Dai fiz o instrumental I e II aqui na FFLCH e todos os níveis do English on Campus. Procuro assistir os filmes sem legendas, entender as musicas e tal. Me viro bem, o problema é com a escrita. Posso afirmar que tenho estudado inglês. Acho q faz uns 6 anos que acabei a última turma e estou retomando agora. Aliás, estou envergonhada com o texto q produzi na aula passada...rs...ficou nítido que preciso fazer uma revisão...rs...

2- Não tenho usado mais pq saí da área de pesquisa de alto nível. Minhas publicações estão mais nacionais. Preciso retomar tb. Meu desempenho oral é regular, posso melhorar. Está satisfeito? Não. Quais são suas principais dificuldades? Vocabulário e gramática (rs...básico...rs...).

3- Liberdade na escrita. Quero me sentir segura para escrever como me sinto para falar. Mesmo achando q seja regular e "apenas" suficiente.

4- Nos abstracts dos textos que já produzi. Pessoas q avaliaram disseram q havia erros mas não os apontaram... Fiquei sem saber..

5- Não. Siiiiimmmmm!!! Nossa! É tudo o que preciso q aconteça!! rs... preciso publicar um artigo urgentemente!!

6- Penso q vocabulário e gramática... desejo q vc me aponte com mais precisão..

7- Bom. As pessoas que lêem costumam elogiar e entender... 


\section{NA}

Idade: 28

Nacionalidade: Brasileira

Escolaridade: Mestrado

Profissão: Tradutora/Professora , atualmente trabalho como digitadora.

1- Comecei a estudar inglês entre 11 e 12 anos, na escola regular. Desde os primeiros contatos com a língua meu interesse em levar adiante esse aprendizado foi despertado, levando-me a ter bastante atenção no que dizia respeito aos meios por onde ela me era transmitida: filmes, música etc. Algum tempo depois, já com 15 anos, recebi uma proposta de um curso de idiomas (por meio da empresa em que meu pai trabalhava), contudo, nessa ocasião, por questões financeiras, não foi possível levar adiante a idéia. Tempos depois, principalmente por conta da minha afinidade com idiomas, optei pelo curso de graduação em Letras; e, aos 18 anos, comecei na universidade pública a estudar de forma mais consistente a língua, tanto nas aulas regulares, como num curso extracurricular, que fiz paralelamente.

2- Atualmente utilizo a língua inglesa basicamente como instrumento para leitura. Nesse momento, estou cursando uma matéria como aluna especial da Pós, cuja bibliografia é quase toda em inglês. Minha leitura geralmente é fluente, mas como o vocabulário da língua inglesa é muito extenso, ainda esbarro em alguns vocábulos, expressões.

3- Meu interesse em participar desse curso veio num momento da minha vida em que eu tento voltar à academia e à minha área de formação. Terminei o mestrado em 2008, e desde então, tenho trabalhado em uma área distinta, e isso tem me deixado muito insatisfeita. Por conta disso, voltei a querer atuar na área de Idiomas, principalmente desejo entrar no mercado de tradução (agências, editoras etc.) e para isso preciso estar treinada para participar de testes escritos com mais tranqüilidade, pois no último que eu fiz não me saí muito bem, estava bastante insegura, e tenho certeza que aconteceu por um distanciamento com o estudo da língua.

4- Costumo escrever nas anotações dos textos que leio, e isso tem acontecido no último mês, numa freqüência de uma ou duas vezes por semana.

5- Não. Mais adiante continuarei com as minhas anotações, e caso surja algum trabalho de versão para fazer.

6- Sim. Nesse momento tenho dificuldade com a espontaneidade em escrever, parece que existe uma distância entre a criatividade, as idéias (texto pensado) e o que resulta disso (texto escrito). Além disso, manter o registro do discurso do início ao fim fica difícil por conta da falta de treino com o vocabulário, bem como a regência dos verbos - questão de gramática mais problemática do inglês, a meu ver. 
7- Acho que tenho uma boa escrita em português, por conta da minha formação em Letras, que me deu subsídios para isso. 


\section{RE}

Idade: 23 anos

Nacionalidade: brasileira

Escolaridade: Ensino superior completo

Profissão: Assitente Editorial Master

1- Comecei a aprender inglês desde o período escolar na verdade. Na época, fazia curso preparatório para o vestibular, o que também reforçava o meu aprendizado da língua inglesa. Em casa, sempre ouvi muito inglês por meio das músicas e filmes, e, além disso, sentia uma "predisposição" para entender sem muita dificuldade o que lia ou ouvia em inglês. No entanto, quando entrei na universidade, em 2004, passei a receber uma carga periódica de "lessons" que foi essencial para o meu embasamento no idioma. Apesar de o curso de Língua Inglesa da faculdade de Letras ter fornecido as diretrizes necessárias para o aprendizado na língua, em quase todos os seus aspectos, ainda sentia necessidade de me aperfeiçoar no inglês, principalmente no que se referia à comunicação verbal. A fala era o meu maior temor. Assim, em 2009, quando conclui meu bacharelado, ingressei numa escola bem-conceituada de língua inglesa para poder me auxiliar nessa minha empreitada. Foi realmente muito produtivo para os meus estudos de língua inglesa. Passei a me sentir mais confiante na fala, bem como no uso das estruturas na escrita. Atualmente estou concluindo o curso regular, e espero cursar os demais níveis avançados.

2- Uso everyday. Trabalho há quase 4 anos no departamento de uma editora conhecida no segmento de livros técnicos-científicos, e lido com textos in english diariamente. Acompanho a tradução, muitas vezes a executo e trabalho com todo o processo de revisão que compõe a produção editorial, que envolve a leitura dos originais em inglês e a respectiva tradução para o português. Também trato diretamente de assuntos internacionais por conta do processo de tradução das obras; assim, escrevo e-mails muitas vezes para editoras do Reino Unido, Estados Unidos e eventualmente para outros países. No início, temia redigir em inglês, acreditando não estar apta a usar a língua na comunicação escrita, mas com o passar do tempo, sentindo o melhoramento das minhas habilidades na língua, passei a encarar principalmente esse processo de comunicação de forma cada vez mais natural. Inclusive superei meu medo de me expressar no dia em que participei de uma reunião internacional no trabalho! Comecei extremamente "travada", mas terminei tranquila e com a certeza de que o native speaker is not a alien!(risos)

Estou satisfeita com relação a um nível intermediário, mas desejo avançar no campo da escrita. Quero estar apta a compor essays, redigir e-mails em inglês sem ficar horas depois revisando, no receio de ter inserido erros na escrita, perder a sensação de estar em uma "prova de fogo" na hora de fazer um abstract e internalizar as regras da escrita, de modo a se tornar mais natural a prática da escrita em inglês.

3- Quando soube do curso "Praticando a Escrita em Inglês", imediatamente me interessei, pois a proposta apresentada iria direto ao encontro dos meus objetivos profissionais e pessoais (quanto à formação acadêmico-cultural). Apesar de até hoje frequentar aulas regulares de língua inglesa em uma escola de idiomas, não sinto uma segurança total na hora de redigir para um native-speaker, por exemplo, ou muito menos verter um texto para o inglês. Antes de iniciar as aulas neste curso de extensão, já imaginava que aprenderia uma abordagem diferente da que até hoje pratiquei, e, somando-se a isso, conheceria novas 
ferramentas (teorias, textos, dicionários, livros, e principalmente praticaria mais) e consequentemente estudaria mais.

Espero que o curso me proporcione uma capacitação na escrita em inglês, na qual eu sinta que realmente poderei escrever de forma apropriada e eficaz, sem sofrer na hora de usar uma "preposition", ou uma “collocation" ou uma "phrasal verb, whatever...mais do que isso, espero alcançar o que a perspectiva proposta realmente propõe, pois assim provavelmente terei vivenciado mais uma forma de aprendizado que me auxiliará a alçar planos mais altos como novas formações na vida acadêmica, por exemplo.

4- Escrevo inglês semanalmente no curso de idiomas, esporadicamente no trabalho em contatos com editoras estrangeiras e raramente com algum colega. Já realizei alguns trabalhos curtos de versão também. De fato, minha prática maior é com a leitura...

5- Sim, na verdade, duas compositions (atividades exigidas no curso de inglês). Espero poder escrever meu journal neste curso all in english.

6- Antigamente, "travava" até para começar. Fazia confusão com os tenses, as prepositions, enfim com toda a parte sintática. No entanto, hoje em dia já me considero um pouco melhor. Sinto dificuldade mais na hora de adotar uma construção mais adequada, ou às vezes com um vocabulary ou ponctuation (por exemplo, uso vários meios, como monolíngues, thesaurus e até mesmo fóruns de discussão, para checar o que é mais usual na língua inglesa e verificar se eles falam daquela forma que expus na minha escrita).

7- Considero ter um bom desempenho na escrita em língua portuguesa. Mas nem sempre foi assim. Quando estudante pré-vestibular, sempre redigia muito nas aulas de Redação, mas invariavelmente recebia uma folha cheia de correções e recomendações. Na faculdade, tinha que me policiar para não escrever além da conta, pois também vez por outra recebia uma orientação dos mestres sobre minhas dissertações. Contudo, quando passei a trabalhar efetivamente com o texto - revisando, reorganizando, compondo, traduzindo, acertando - pude me aperfeiçoar cada vez mais no uso das inúmeras ferramentas que dispomos para escrever. A leitura consecutiva dos mais variados textos, a rotina de consultas a manuais, gramáticas, dicionários, guias entre outros e principalmente a retomada dos estudos em casa foram fundamentais para o meu aperfeiçoamento no processo da escrita. 


\section{LU}

Idade: 36 anos

Nacionalidade: brasileira

Escolaridade: pós-graduada

Profissão: professora

1- Comecei a estudar inglês em escola de idiomas aos 10 anos, o curso durou 8 anos (CCAA), ao término foi para os EUA, onde estudei inglês em escola de idiomas para estrangeiros por 3 meses, tive oportunidade de morar em casa de americanos durante os 2 primeiros meses e depois foi para o dormitório da universidade. Ao retornar ao Brasil, foi convidada a trabalhar numa escola de idiomas, depois de 7 anos, resolvi então fazer o curso de letras. Estudei na Universidade Anhembi Morumbi, que oferecia um curso com habilitação somente em inglês, daí continuei estudando inglês, o que tenho feito até os dias de hoje.

2- Faço uso diariamente, claro que ao lecionar cursos iniciais e básicos, o uso é muito pouco, por isso, estou sempre procurando um curso novo, onde posso praticar e tentar melhorar o que já aprendi. Satisfeita, nunca. Tenho dificuldades quanto a prática auditiva, mas isso é algo que não se restringe ao inglês, sinto o mesmo problema com o português.

3- Ao terminar meus estudos no curso de idiomas era muito nova e não tinha noção da necessidade dos certificados internacionais. Após isso, na época da faculdade, 10 anos atrás, a professora disse que se estudasse e tomasse conhecimento do exame, poderia fazer o CAE, no entanto, às vezes por falta de tempo, às vezes por falta de recursos, não fiz. Mas, agora, na escola onde trabalho é extremamente importante, tanto que eles oferecem um curso preparatório para os interessados, dessa forma essa chama foi acesa novamente. Entretanto, não estou gostando da forma que o professor trabalha, assim, ao verificar que este curso seria oferecido, optei por fazê-lo a fim de desenvolver esta habilidade. Não tenho o feedback do outro professor, apesar de já ter comunicado que preciso deste, acho que mesmo sem ter muito conhecimento prévio deste curso oferecido pela USP, ele vem de encontro com o que estava esperando. Além disso, sou uma eterna estudante, mesmo se não tivesse este propósito, acho que me inscreveria para o curso.

4- Na época da graduação e pós-graduação escrevia com maior freqüência, atualmente, faço alguns relatórios para a escola onde trabalho que devem ser em inglês, mas são textos breves e simples, nada que me faça estudar novos vocábulos.

5- Não. Pretendo praticar nos próximos meses para enfim por volta do primeiro semestre de 2011 fazer o exame que mencionei anteriormente.

6- Acho que as maiores dificuldades são quanto ao vocabulário (sinônimos), collocation, e qual a melhor opção quando existem palavras que podem ser sinônimas, mas apresentam uma sutil diferença, que podem modificar o que se pretende dizer. 
7- Sou muito exigente, e português nunca foi meu forte, tanto que escolhi a universidade para cursar letras justamente porque ela oferecia uma única habilitação (inglês), onde a única aula de português que tive foi de português para estrangeiros, tudo muito superficial. Já tive que lecionar português para suecos e argentinos, mas só aceitou para colaborar com a escola em que trabalhava, no entanto, por curto período. Hoje entendo que foi um trauma causado na infância, quando tinha que decorar tempos verbais, até hoje tenho pavor deles. Pelo que expus, posso afirmar que esta entre bom e razoável. 


\section{SA}

Idade: 37 anos

Nacionalidade: brasileira

Escolaridade: supeior completo, com especializações e mestrado

Profissão: engenheira química

1- Comecei o aprendizado de inglês a partir da $5^{\text {a }}$. série (11 anos) em uma escola municipal de São Paulo. Entrei para o CCAA aos 12 anos, mas considerei o curso muito fraco, mudando para o Centro Britânico, que possui a mesma metodologia da Cultura Inglesa, estudando até os 14 anos. Nos anos seguintes, apenas tive aulas no colegial. Durante a faculdade tive contato com muitos livros em inglês, inclusive, algumas disciplinas disponibilizavam apenas material em inglês. Após estar formada, ingressando no mercado de trabalho, voltei ao Centro Britânico por mais um ano e consegui o certificado intermediário do Cambridge. Comecei a ler vários livros de ficção em inglês e todo o material técnico utilizado na minha carreira profissional é em inglês. Durante o mestrado realizei os curso de escrita acadêmica e apresentação de trabalhos em inglês, oferecidos pela POLI para os estudantes de pós-graduação. Atualmente, sempre leio um livro de ficção em inglês e assisto filmes e seriados sem legendas ou com legendas em inglês. Nunca realizei intercâmbio, mas já tive contato com falantes nativos em viagens de turismo e durante o trabalho.

2- Considero o inglês suficiente para ouvir, bem fluente para ler e razoável para escrever e falar. Não estou satisfeita. Preciso desenvolver a escrita e a fala.

3- Considero que tenho certo bloqueio para a escrita e fiquei entusiasmada em participar de uma nova metodologia de ensino que incentiva a escrita freqüente.

4- Eu deveria escrever artigos científicos em inglês. A minha frequiência atual é nula e já me prejudiquei, pois deixei de publicar um trabalho de 20 páginas em um congresso no mês de maio deste ano. Preciso redigir sempre, mas não sei quanto que é o "sempre".

5- Atualmente não estou escrevendo nada e preciso escrever no futuro próximo (deveria ser o mais breve possível).

6- Sim, tenho muitas dificuldades. É muito doloroso começar e sempre tenho desculpas para não continuar.

7- Não considero o meu desempenho bom em português, mas também não acho que seja ruim. Falta a classificação razoável, que tal? Se ela não for válida, considerarei o meu desempenho bom (bem tímido). Acho que não tenho o hábito de escrever e que o que eu produzir não será avaliado para o meu aprimoramento. Considero que tudo o que eu produzir será apenas aprovado ou reprovado e não terei um "feedback". 